\title{
Books, Prints and Drawings: The Musaeum as a Centre of Visual Documentation
}

\subsection{Introduction}

It should be noted that in Strada's own descriptions of his Musaeum quoted at the beginning of the last chapter, contemporary works of art-paintings — are mentioned only twice and only in passing. Either they seem to have been of less importance to Strada than his medals, his antiquities, his books and his rare manuscripts, or they did not fit his perception of the preferences of the particular patrons addressed. In these descriptions he never refers to the prints and drawings in his collection, though from other sources we know that those in fact constituted a very substantial part of his holdings. Moreover they constituted the part which appears to have been of the greatest immediate practical use - many examples of this have been advanced in Part II of this study - and which was most explicitly exploited in Strada's own projects, such as the libri di disegni he prepared for his patrons and his projected publications. In view of the size and importance of his holdings an analysis of the available information is useful, not only for the light it throws on Strada's preferences and procedures, but also for the history of the collecting of drawings in general. After his death his collection must have been one of the major sources tapped by the better documented collectors of the seventeenth century-apart from Rudolf I one thinks of Paul von Praun, Lord Arundel, Cassiano dal Pozzo and so on.

The list of 'Pleasant canvases' and other objects Strada offered to the Duke of Bavaria sometime in the 1570 s includes a few works on paper which have not yet been mentioned in the preceding chapter. They are described as follows:

5 books of various sorts of good engraved works of art

1 small chest, in it many large and small works of art engraved in copper by many masters and made by hand:

1 big book, Cosmographia and many fortresses

1 book about architecture. ${ }^{1}$

1 Cf. Appendix C; cf. Stockbauer 1874, p. 44. Note that the latter two items may possibly have been albums of prints (and drawings), instead of illustrated publications.

(C) DIRK JACOB JANSEN, 2019 | DOI:10.1163/9789004359499_015 
The first two items comprise woodcuts and engravings partly bound together or organized in albums of blank sheets, partly preserved unbound in a wooden box. The 'big book', is probably a copy of the 1550 edition of Sebastian Münster's Cosmographia; the 'fortresses' refer either to the town-views-such as that of Vienna-included in it [Figs. 13.1-13.2], or to a set of additional images collected elsewhere that had been inserted into it. The book about architecture can be any recent architectural treatise, most likely one of the many editions of Serlio.

These items represent what must be a small supernumerary section of perhaps the most important and influential part of Strada's Musaeum, his collection of visual documentation. In contrast to the collection of paintings, of which he appears to have been ready to sell a substantial, if not the major part, from his collection of graphic material he only offered prints and illustrated printed books: such non-exclusive material probably consisted of doubles from his own collection or were even part of his regular stock as a bookseller. They do, however, represent themes that we know to have been close to his heart and which were well represented in his Musaeum: contemporary graphic art, topography and architecture. In the following I will recapitulate the genesis of Strada's collection of graphic material, and attempt a partial characterization on the basis of the scanty documents that are relevant. This survey will consist of two parts: one devoted to Strada's acquisition of quantities of existing drawings by some of the principal artists and architects of the Italian Renaissance, and one to his purposeful commission of documentary drawings of both ancient and contemporary monuments.

\subsection{Strada's Acquisition of Drawings}

As has been related in Chapter 3.8, on his travels in the mid-1550s Strada could acquire a vast quantity of drawings of some of the most esteemed masters of
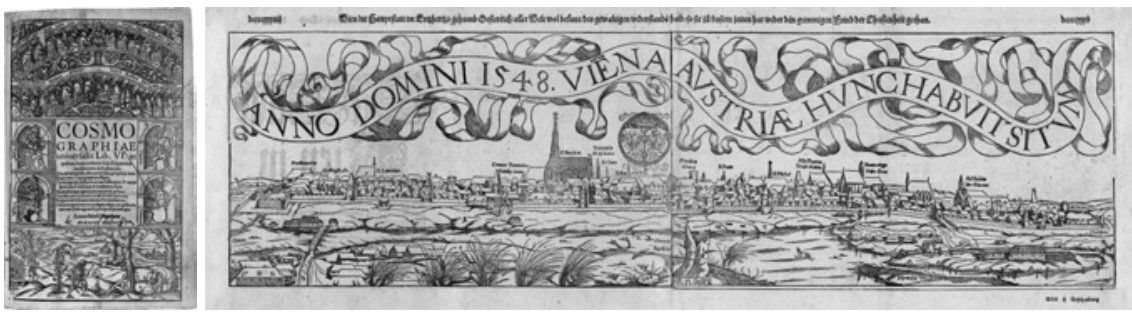

FIGURES 13.1-13.2 Sebastian Münster, Cosmographiae universalis Libri VI, title page of the Latin edition, Basle $155^{\circ}$ and View of Vienna, woodcut from from the German edition. 
the High Renaissance. During his stay in Lyon he could buy both the manuscripts of the architectural treatise of Sebastiano Serlio, and the collection of drawings he had brought together during his long life. When he subsequently arrived in Rome he likewise purchased the entire paper inheritance of his old friend Perino del Vaga, which included both Perino's own drawings and many of other artists, including Raphael, who had been his teacher. On his way back to Germany Strada visited his hometown, Mantua, and persuaded Giulio Romano's feckless son Raffaello-named after Perino's and Giulio's common master - to part with all the drawings he had inherited from his father. In the preface to his edition of Serlio's Settimo Libro Strada provides a glowing account of these acquisitions, of which he was very proud. Strada makes clear that these artists had collected not only their own works, but also that of their masters and of other artists, and also of other regions. For instance both Serlio's collection — where one would expect it — and Perino's—-where it would be less obvious-included architectural drawings from France. ${ }^{2}$

Strada, in his pride of his Musaeum, might easily have overestimated the importance of his acquisitions. Therefore it is fortunate that his enthusiastic account is partly corroborated by a passage in Giovanni Battista Armenini's De veri precetti della pittura. As a young painter, just arrived in Rome from his native Ravenna, Armenini was employed by Strada as a draughtsman. Living in the latter's house in Rome, he was allowed to study the drawings from Perino's estate at leisure. He also makes clear that Strada was quite open handed and paid high prices for the things he valued, and stresses that Strada paid 'realmente' for his commissions. ${ }^{3}$ Strada's strong financial position, coupled with his obstinacy and perfectionism, suggest that he did not greatly exaggerate when he claimed to have acquired not only Serlio's entire collection, but also all of Perino's and Giulio Romano's graphic material that remained in the possession of their heirs - to the effect that

$<\ldots>$ those expert in the arts can well judge how many beautiful things I have, having obtained the labours of three such great men. ${ }^{4}$

2 Serlio 1575, preface, fol. a iiii-r.: 'Fra questi disegni [= Perino's drawings] ne trovai una grandissima quantità d'Architettura, tanto di quegli di Roma, quanto di Francia, et altri luochi della Italia'.

3 Armenini 1587 , p. 180 ; ibid., pp. $64-65$, states that Strada paid Catarina Penni fifty scudi for her husband's drawings. Is this the first sale of master drawings of which the price has come down to us? It seems a rather modest sum in view of what the purchase included; but Armenini may have witnessed the payment of one instalment of a cumulatively much larger sum.

4 Serlio 1575, preface, fol. a iiii-r.: '< ...>a tale, che quelli de l'arte possono far giudicio quante belle cose mi truovo: havendo di tre tanto grand' huomini havuto le fatiche'. 
If Strada was prepared to invest so much money in these huge acquisitions of drawings, it can be assumed that he also regularly bought smaller quantities of drawings and even individual sheets by other masters. He must, for instance, have been particularly eager to acquire some works by Polidoro da Caravaggio, the artist who most perfectly matched the Antique, and by the master who most widely surpassed it, Michelangelo. ${ }^{5}$ Since Strada appears rarely to have annotated his drawings, it is well-nigh impossible to decide which individual sheets once may have belonged to his collection. But at least it is possible to list the various components of the collection as far as these can be inferred from these sources.

It is not surprising that in his preface to Serlio's treatise on architecture Strada particularly stressed the architectural designs included in his purchases; this does not, however, indicate that other types of drawings were less well represented, as has been suggested by Beket Bukovinská and Eliška Fučíková. ${ }^{6}$ Of course the architectural drawings predominated among the material he acquired from Serlio. According to Strada his acquisitions consisted not only of drawings by Serlio himself, but also of those by other masters that Serlio had collected during his long career both in Italy and in France. It is very likely that they included in particular those that he had inherited or copied from his friend and teacher, Baldassare Peruzzi. This material probably also included earlier Sienese material on architecture, such as drawings and texts by Peruzzi's compatriot, Francesco di Giorgio Martini, whose treatise was one of Serlio's sources of inspiration, and upon whose technical designs Strada drew for his treatise on watermills, fountains and other technical inventions. ${ }^{7}$ And it included the various designs (or copies of these) from the circle of Bramante, Raphael and the Sangallo circle that were used by Serlio in the preparation of his treatise. Perhaps it was Serlio that had acquired the military treatise by

5 Polidoro da Caravaggio is not mentioned in the sources documenting Strada's acquisitions and possessions; but the facade of the Palazzo Gaddi in Rome, decorated by Polidoro, was probably among the monuments he had documented in the 1550 s. Drawings by or after Michelangelo are mentioned among works offered from his collection by Ottavio Strada after his father's death, as are some attributed to Parmigianino. Strada often took advantage of opportunities of acquiring works of art, as is borne out by the ample collection of Dürer prints he acquired, probably during his residence at Nuremberg (all discussed below).

6 Bukovinská/Fučíková/Konečný 1984, p. 65. I cannot agree that Strada in the context of his preface to Serlio would necessarily have singled out Giulio's goldsmith work designs, when he had already stated explicitly that he acquired all of the material ('tutti li disegni') that had remained in Raffaello Pippi's hands. The stress on architecture is natural in the preface to an architectural treatise, and in any case the relevant passage is very brief.

7 On this treatise, see Marchis/Dolza 2002 (also including papers by Thomas DaCosta Kaufmann and Dirk Jansen) and Dolza 2003. 
Guillaume du Bellay which Strada intended to add to his planned edition of Serlio's Castrametatio. ${ }^{8}$ Likewise I suspect that some of the material by Serlio's French colleague and rival, Jacques Androuet du Cerceau, which is preserved in the Munich Staatsbibliothek, was supplied by Strada to his patron, Hans Jakob Fugger, together with the Munich versions of the Sesto Libro and the Castrametatio. Strada could have obtained these together with Serlio's effects, or have acquired them independently during his stay in France. ${ }^{9}$

Among the drawings Strada acquired from the heirs of Perino and Giulio the proportion between figure-drawings and architectural and decorative designs will have been more even. Strada claimed that, in addition to their own work, the collections of both Perino and Giulio included many drawings by Raphael, whose pupils and assistants they had been. The tale of Raphael's drawings after his death has been summarized by Konrad Oberhuber in his preface to the ninth volume of the Corpus of Raphael's drawings of 1972. ${ }^{10}$ Vasari states that the drawings left at Raphael's death were divided between two of his collaborators, Giulio Romano and Giovan Francesco Penni. It is not known what happened to Penni's share when he died, but it is likely that part or all of it ended up with his one-time partner Perino, who had married his sister Catharina. This implies that by means of his purchases from Perino's and Giulio's heirs Strada reunited the greater portion of the drawings of Raphael's later period, the years 1511-1520 covered by Oberhuber's volume of the Corpus. At a later date Strada in fact made special mention both of Raphael's original drawings for the Vatican Stanze, and of Giulio's designs for the double frieze in the Camera degli Stucchi in the Palazzo del Te that were among his possessions. ${ }^{11}$ The presence in Munich of the manuscript translation of Vitruvius, made on behalf of Raphael by his humanist friend Fabio Calvo, is likewise best explained by the supposition that Strada supplied it to Fugger or to Duke Albrecht, having acquired it with Perino's or Giulio's Nachlass. ${ }^{12}$ The mere fact

$8 \quad$ According to the copyright privilege Strada obtained from Maximilian II in May 1574 [Doc. 1574-05-30].

9 Various volumes including drawings and prints in the Bayerische Staatsbibliothek in Munich are now accessible through the website of Codicon, such as Cod. Icon. 191, attributed to Du Cerceau, and Cod. Icon. 195, attributed to Jean de Chenevières; these give an impression of the type of material Strada acquired.

10 Oberhuber 1972, pp. 18-20.

11 Index sive catalogus, Appendix D, nrs. 43 and 14. Many of Giulio's original designs are now in the Louvre; the complete set in the Albertina doubtless is the copy Strada prepared or commissioned for the engraver (cf. below, Ch. 13.7·3).

12 Bsв-Hs, Cod. ital. 37. The supposition by the modern editors of Calvo's manuscript that it had been acquired in 1770 by Elector Carl Theodor with Piero Vettori's library (Fontana/Morachiello 1975, pp. 15 ff. ) is contradicted by its presence among the architectural 
that relatively few of Raphael's drawings from this period appear to have survived suggests that they shared a common, probably cruel fate; and the suspicion that this fate might be identical with that of other sections of Strada's collection is only reinforced by the fact that of Giulio's architectural drawings and of many other essential components of Strada's Musaeum - including his own manuscripts - very little has come to light. ${ }^{13}$

Perhaps a detailed examination of the available sources might allow a partial reconstruction of Strada's graphic collection, or at least a tentative characterization of its contents. Here I must limit myself to suggest the sources that could be used, and give a few examples of the sort of information these might yield. These sources include the graphic materials still preserved in a context which directly connects them to Strada's collection; the few individual drawings that can be shown by internal evidence to have been in his possession; the libri di disegni prepared in his workshop, the sheets of which were based on original material in his own collection; and finally the archival sources relating to the fate of his Musaeum after his death.

\section{3 'Owls to Athens': Some Documents Relating to Strada's Graphic Collection}

The latter sources do provide some concrete information which helps to visualize fragments of Strada's collection of drawings. After Strada's death his Nachlass was left under seal until his two eldest sons had settled the dispute that had arisen. Once the estate had been divided both sons attempted to sell sections of the library and the Kunstkammer. Thus in 1594 Paolo Strada approached Landgrave Moritz of Hessen-Kassel offering him a choice from 'die bei ernanndten lieben Vatter nach Imo gelassen Antiquiteten und kunstlichen Abrissen', including twenty-one gesso imperial portrait busts, a number of printed books, a 'Model' or set of plans for a palace drawn by Paolo himself, three albums of numismatic designs and one containing hundred and thirty designs for costumes for courtly entertainments. These festival drawings were

treatises listed in the inventory of the Munich Kunstkammer by Johann Baptist Fickler (1598) and in another, even earlier list of architectural books in Munich; cf. above, Ch. $3 \cdot 7$, note 85 .

13 One might for instance think of the storm in 1792 wrecking the ship that carried a large part of the collection of Duke Albert von Sachsen-Teschen, the founder of the Vienna Albertina. 
all products of Strada's workshop, rather than remnants from his collection. ${ }^{14}$ Ottavio, on the other hand, did on various occasions attempt to sell what he presented as remnants from his father's collection of prints and drawings. Here I will limit myself to listing these attempts and provide his descriptions, which give at least some idea of size and quality of this section of his father's Musaeum.

Ottavio's first attempts date from shortly after Jacopo's decease, which implies that they are concerned with material from his father's collection he had already brought into his possession long before Strada made his will in 1584 . In this will Ottavio was almost totally disinherited, for reasons the stating of which took three of the eight pages of the document, and of which the rape and attempted murder of his father's 'concubine' is only the most shocking. One of the crimes with which Strada taxed his undutiful son is the alienation of part of his collection of drawings:

Seventh, he has outright stolen, and scandalously squandered my best antique coins, called medals; and other medals, my best, that belong to the series of the Emperors; moreover my dearest, and most beautiful designs ['Contrafectur'], drawn by hand, which I have brought together since my youngest years, and which have cost me a lot of money; as well as other things. ${ }^{15}$

It is natural that this will gave rise to litigation between Ottavio and his brothers and sister, which continued long after the formal opening of the will, which itself took place only on 28 September 1590, that is almost two years after Strada's death. Meanwhile Strada's studio, in Vienna, was under seal, and thus not accessible to Ottavio, who in any case was living in Prague and did not come to Vienna until the summer of $1589 .{ }^{16}$ But already on 6 December 1588 he wrote to

14 Doc. 1594-12-23. Some of these festival drawings were made by Paolo Strada himself; on Strada's festival designs, see above, Ch. 4.3.5.

15 Doc. 1584-07-01; Appendix B. The will is discussed in greater detail below, Ch. 14.10.

16 Doc. 1584-07-01: the original of Strada's will bears a note that it had been opened by the Landesmarschall of Lower Austria, in the presence of Ottavio and of Paolo, also as representative of his young half-brother Tobia, on 28 September 1590. In a letter to Belisario Vinta of 10 April 1590 Ottavio refers to three illustrated manuscript books in which his own patron, Emperor Rudolf II, was interested, but which Ottavio preferred to sell to the Grand Duke (doubtless in view of Rudolf's notorious procrastination in paying) so he had put off the Emperor by telling him that they were still in Vienna under seal ('e molte volte S.M.C. mi da domandare de questi libri, dove sempre trovo scusa che sonno in Vienna nel studio seratij)'; in a subsequent letter of 17 June 1590 Ottavio refers to the litigation with his brother (ASF, Medici del Principato 814, fol. 343; 817, fol. 72). In the end the litigation 
Belisario Vinta, secretary of Ferdinando I de' Medici, Grand Duke of Tuscany, informing him of his father's decease a few weeks earlier, and then offering to present some of the effects he had left to the Grand Duke: a numismatic manuscript, dozens of 'belissime Medaglioni' and other objects, and he also promises a gift to Vinta himself. Almost as an afterthought, he then continues:

We also still have beautiful drawings by the hands of Michel Angelo, Rafael Urbino, Pirin del Vaga, Francesco Parmesano, Julio Romano etc., that my father considered his [greatest] treasure; and to us they are useless, whereas over there [in Tuscany] they would be prized; and my father had the opportunity to buy them, being in Italy at that time, when these excellent men ['valenthuomini'] were living. ${ }^{17}$

There was no immediate response to this offer, and Ottavio did not pursue the matter. But by August 1589, when he had come to Vienna, he claimed to have obtained access to his father's studio, one item of which he now offers to the Grand Duke:

Some months ago Signor Curtio da Picchena asked me to help him find designs by Alberto Durero, for which he had a commission from Duke Virginio [= Virginio Orsini, Duke of Bracciano, nephew of the Grand Duke]; for His Excellency wished to bring together a book of such designs.<...> Now if I knew that His Highness [= the Grand Duke] would be interested to have a similar book, I now possess one, which I inherited from the studio of my father, who considered it a jewel and has never wanted to part with it, and in the said book there are the most beautiful and best printed designs that the said Alberto Durero ever made. ${ }^{18}$

was resolved in some sort of settlement, referred to in a note on the copy of Strada's will in the Vienna Nationalbibliothek.

17 ASF, Medici del Principato 810, fol. 129: 'ce ne ritroviamo ancora de belissimi disegni fatti a mano d' Michel Angelo, Rafael Urbino, Pirin del Vaga, Francesco Parmesano, Julio Romano etc., che mio padre [ebbe?] per il suo Thesoro; et a noi non serve niente, et costì sarebbano in stimatione; et mio padre hebbe commodità a comprarli, trovandosi in quelli tempi in Italia, quando vivevano tali valenthuomini'.

18 ASF, Medici del Principato 807, fol. 275, Ottavio Strada to Belisario Vinta, Vienna,28 August 1589: 'essendo alcuni mesi, che'l S[igno]r Curtio da Picchena mi pregò che volessi aiutar di cercare disegni del Alberto Durero, che sua sig[noria] haveva commissione di del S[igno] re Duca Virginio, che Sua Ex[cellen]za voleva meterci un libro insieme di tali disegni<...> Hora se io sapessi che Sua Al[tez]za suo padrone havesse desiderio di haver un simil libro, io me ne ritrovo hora uno, che hereditai del studio di mio padre, el qual teneva per un gioia e mai senel ha volsuto privarsene, et sonno gli piu belli et ben stampati disegni in 
There is no evidence that the Grand Duke reacted to this proposal, but he did remember Ottavio's earlier offer of the drawings by Italian masters, as is clear from a letter to Vinta from Niccolò Gaddi, dated 'in Villa' the 13th October following. Gaddi was himself a noted collector and connoisseur with a particular interest in drawings, as his acquisition of Vasari's 'Libro di disegni' indicates. He was one of the principal artistic consultants of the Florentine court, and in this capacity he had been asked to give an appraisal of the manuscripts that Ottavio had sent. After responding to this request, he continues:

The most Serene Grand Duke some days ago told me that he [= Ottavio Strada] also had a quantity of drawings by the hand of excellent painters and sculptors, and that he was willing to send these; if one let them come, and be told the price, having seen what they were, one could give him an answer. ${ }^{19}$

This advice was taken, so in January following (1590) Ottavio sent a parcel of two hundred and forty drawings of various sizes to Florence. These were the drawings he had with him in Prague: the greater part of the collection, '<... fra li quali sono molti belle Historiae et inventione $<$... >' was still in Vienna, where he hoped to go the coming summer. In case this might please the Grand Duke, he would also send 'qualche cosa de bella' from there. In his covering letter to the Grand Duke himself Ottavio courteously refused to mention a price for the drawings he sent: 'tutto quello che me darà, accetarò in gratia, et cusì gli fo un presente'; but in his letter to Vinta of the same date he was more business-like, and valued them at one hundred gold scudi at least. He further offered to send a series of drawings by Giulio Romano, bound in an album

$<\ldots>$ in which there is nothing else but extravagant inventions to grace the sideboard of a great Prince, a thing quite wonderful to see. ${ }^{20}$

esso libro, che detto Alberto Durero ha fatto'. A day later Ottavio wrote a letter to Duke Virginio himself proposing the Dürer album to him in almost the same terms, adding 'io so che in tutta Italia non sene trovara un simil libro, che è ben conservato et gli disegni tanto politi che ben stampati che è una gioia a vedere<...>' (Rome, Archivio Capitolino, Archivio Orsini, serie I, vol. 124, nr. 198); I am grateful to Robert Lindell who found this letter and communicated it to me.

19 ASF, Medici del Principato 822, II, fol. 876: 'Il Serenissimo Granduca più giorni fa mi dette che [Ottavio Strada] haveva ancora una quantità di disegni a mano di valenthomini pittori e scultori, et che li voleva mandare; quando si facessino venire, et si intendesse il prezzo, visti che fussino, se li potrebbe rispondere'.

20 ASF, Medici del Principato 813, f. 110: Ottavio Strada to Ferdinando, Grand Duke of Tuscany, Prague 15 January 1590: 'Mi ritrovo un libro di mano di Julio Romano, dove in esso non c' 
The drawings soon arrived in Florence, and seem to have been eagerly expected, since already on 11 February Vinta could communicate the reactions to Ottavio. Though this letter has not been preserved, from Ottavio's reply it is clear that its contents rather upset him. And this is not surprising, since he was told that in Florence all the drawings he had sent were held to be mere copies. Ottavio was offended, and said so; though he admitted that there might well be one or two copies among them, 'sia come si voglia', he strongly asserted his good faith:

I swear on my honour as a gentleman that my father valued them so highly that he would not have given them for 300 gold scudi, and he has lived at the time when these excellent masters were alive and he bought [the drawings] from them. Here [in Prague], before I sent them over there [to Florence] a Frenchman has offered me hundred Thaler, and I did not want to give them to him [for that price]. ${ }^{21}$

Therefore in case his drawings did not please the Grand Duke, they should be sent back well wrapped: in Prague there were people eager to have them, and prepared to pay a good price. This suggestion was accepted in Florence, and less than a month later the secretary of the Tuscan envoy in Prague had handed over a sealed parcel of drawings to Ottavio. ${ }^{22}$

After this disappointing experience, Ottavio did not attempt to interest the Grand Duke in the remainder of his father's drawings, that is, those that had remained in Vienna. By a curious coincidence, however, the Florentine State Archive contains one more letter of Ottavio's that gives further information of what at that time was still left of Strada's graphic collection. This letter, dated Prague, November 1st of the same year (1590), was addressed to Prospero Visconti, a Milanese nobleman whom we have already met in the last chapter. As an expert and agent in antiquities and works of art Visconti had been a colleague and acquaintance of the elder Strada and had visited his studio when in

è altro, solum inventioni stravaganti per far una credenza di un gran Principe, cosa molto bella da vedere<...>'; Medici del Principato 814, f. 40, Ottavio Strada to Belisario Vinta, 15 January 1590.

ASF, Medici del Principato 814, f. 343, Ottavio Strada to Belisario Vinta, Prague 10 April 1590, 'gli giuro da gentilhuomo che mio padre non haveria dati per 300 [scudi] d'oro, in tanto reputatione le tenevi, et gli'è stato vivo nelli tempi di quei valenthuomini che gli hanno fatti, et da loro comprati. Qui, avanti che gli mandai costì, un francese me offerse cento tallerij, non gli volse dargli<...>

22 ASF, Medici del Principato 817, fol. 72, Ottavio Strada to the Grand Duke of Tuscany, Vienna 17 June 1590. 
Vienna attending the wedding festivities of Archduke Charles in 1570. Ottavio obviously was well aware of Visconti's close relationship with Duke Wilhelm $\mathrm{V}$ of Bavaria, for whom he arranged extensive acquisitions of antiquities and contemporary works of art from Italy. ${ }^{23}$ Besides some examples of his own industry, Ottavio offered to Visconti several volumes of drawings and prints, which he described as follows:

Two large books bound with gold, on paper of medium size; in the one are the greater part of the printed designs of that great master Alberto Durero, both the copper engravings, and the woodcuts, and they are 216 pieces; and these are all early impressions.

In the other book are 300 pieces of designs of those ancient masters such as Michel Angelo, Raphael Urbino, Francisco Parmesano [= Parmigianino], Julio Romano, Luca d'Holanda [= Lucas van Leyden], and other great masters, things of a kind which these days can no more be found for sale.

Then there is also the Porton of Albert Durero [= Dürer's Ehrenpforte ], in which are engraved the exploits of the Emperor Maximilian I.

Another book made by hand, in which there are 300 pieces of designs of these great masters that are mentioned above, in their own hand. ${ }^{24}$

It can be assumed that the album of Dürer prints is identical with the one Ottavio earlier had offered to the Grand Duke and to Duke Virginio. From the context it is clear that the first group of three hundred 'disegni' by Italian masters, which was bound as a companion piece to the Dürer engravings and woodcuts, likewise consisted of prints, which Strada will have collected both during his stay in Rome in the 1550 os and afterwards. The second group, consisting of three hundred autograph drawings of these same masters which were bound in a similar album, I think must have been part of the drawings that had remained in Vienna, and to which Ottavio had referred in his earlier letters to the Grand

23 ASF, Medici del Principato 825, fol. 318; on Visconti, see Simonsfeld 1902.

24 'Dui libri grandi ligati con ori [sic], in carta mediana; in el uno sonno li maggior parte delli disegni stampati di quel valenthuomo Alberto Durero, cusì quelli in rame, come quelli in legno, et sonno da 216 pezzi; et tutti sonno delle prime stampe. Nel altro libro sonno da 300 pezzi di disegni di quelli maestri antichi come di Michel Angelo, Raphael Urbino, Francisco Parmesano, Julio Romano, Luca d'Holanda, et altri gran Valenthuomini, non trovandoli per questi tempi più di comprare simil cose. Ciè ancora il Porton di Alberto Durero, dove sciso sonno i fatti di Maximiliano I Imperatore. Un altro libro fatto a mano, in el qual sonno da 300 pezzi di disegni di quelli Valenthuomini et loro proprio mani, come di sopra sonno nominati'. 
Duke. It was obviously not identical with the parcel of two hundred and forty unbound drawings actually sent to, and returned from Tuscany, which perhaps Ottavio did not risk to expose a second time to the judgment of an Italian connoisseur. In this he was not ill-advised, in view of Visconti's quite sceptical reaction to the material Ottavio did propose to him. The Count did not wish to retain any of this for himself, but he did send Ottavio's letter to Florence: the Grand Duke might find something to his taste, though Visconti did not really expect that, noting in his covering letter that:

$<\ldots>$ benchè quanto a me, io credo che a portare tali cose a Fiorenza sia portare a Samo vasi, nottole a Attene, e cocodrilli a Egitto.

$<\ldots>$ As far as I am concerned, I believe bringing such things to Florence is like bringing vases to Samos, owls to Athens, and crocodiles to Egypt. ${ }^{25}$

In view of his disappointment at the earlier consignment of Ottavio's drawings it is perhaps not surprising that the Grand Duke did not show any interest, and Ottavio had to look elsewhere for buyers.

Ottavio's correspondence as found in Florence contains no further references to his father's drawings, and it will be convenient once more to sum up what the written sources list as items from Jacopo's Musaeum. The list of paintings and other works of art probably sent to the Munich court by Strada himself includes two items:

1. Five books or albums of various sorts of 'good engraved works of art', and 2. One small chest containing many large and small copper engravings

These may or may not have been in part identical with two of the items mentioned in Ottavio's correspondence with the Tuscan court, with the Duke of Bracciano, and with Prospero Visconti:

3. A volume containing two hundred and sixteen prints by Albrecht Dürer. This was offered by Ottavio to Grand Duke Ferdinando I of Tuscany and to Virginio Orsini, Duke of Bracciano, and later to Prospero Visconti.

4. A copy of Dürer's Ehrenpforte (if complete that would be hundred and ninety two sheets in all).

5. A set of three hundred prints by (mostly) Italian Renaissance masters. This was bound as a companion volume to the Dürer prints, and included works by or after Michelangelo, Raphael, Parmigianino, and Giulio Romano, but also by Lucas van Leyden, and was bound as a companion volume

25 ASF, Medici del Principato 825, fol. 317, Prospero Visconti to Marcello Accolti, secretary to the Grand Duke of Tuscany, Milan 6 February 1591. 
to the volume of Dürer prints. Ottavio offered it to the Grand Duke and to Prospero Visconti.

6. A set of two hundred and forty unbound drawings of various sizes by Italian masters of the Renaissance. Ottavio claims that these were autographs of Michelangelo, Raphael, Perino del Vaga, Parmigianino, Giulio Romano and others. It appears that Ottavio had removed these drawings from his father's studio already before 1584, the date of Jacopo's will, and had later sent them to Florence, where they were considered to be copies.

7. An album of three hundred autograph drawings attributed to these same 'valenthuomini'. Ottavio proposed this album to Prospero Visconti.

8. A collection of 'inventioni stravaganti' for a prince's sideboard, attributed to Giulio Romano: designs for vases 'all'antica' and for other types of goldsmith work, likewise collected in a bound volume. Ottavio offered it to the Grand Duke.

\subsection{The Contents of Strada's Collection of Prints and Drawings}

\subsubsection{The Prints}

As in the case of the paintings, these documents do not allow to identify individual sheets from Strada's print room, but it does give sufficient information to evoke some notion of what it may have contained, and consequently what impression it made on its visitors. That is the easiest in the case of the prints, in particular those of Dürer. With two hundred and sixteen sheets the Dürer album represented a substantial part of that master's oeuvre, and probably included his most famous images, such as Knight, Death and the Devil and Melencolia I [Figs. 13.3-13.4]. That Strada's estate also included a set of the Ehrenpforte - its hundred and ninety two separate sheets doubtless loosely gathered in an album - testifies to his great respect for the works of the Nuremberg master [Figs. 13.5-13.6].

It moreover correlates to his interest in the biographies of the Roman emperors, including their medieval and modern successors. In the 1540 S Strada had lived only a few doors away from Dürer's house, so he could know his reputation at first hand from his neighbours' reports, and must have had access to his works through his connection with Nuremberg artists and with the circle of patricians who had commissioned or collected his works, such as Willibald Imhoff. These connections stimulated his interest in Dürer's work and may have facilitated his acquisition of a copy of the Ehrenpforte and a quantity of the master's prints that was exceptional even at the time. 

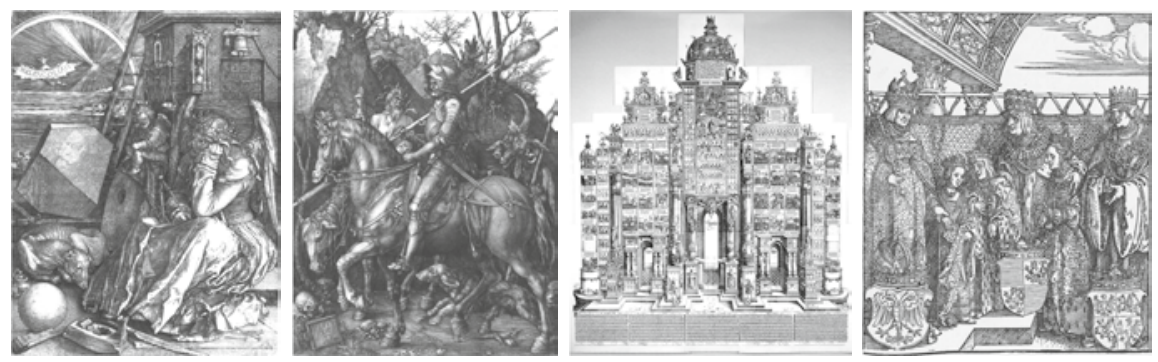

FIGURES 13.3-13.4 Examples of the type of material present in Strada's print collection: Albrecht Dürer, Melencolia I and Knight, Death and Devil, engravings.

FIGU RES 13.5-13.6 Albrecht Dürer, The Triumphal Arch, a woodcut series commissioned by Emperor Maximilian I, showing the whole Ehrenpforte mounted as intended, and one of its 192 individual prints, depicting the double marriage arrangement contracted by the Emperor for his grandchildren Ferdinand and Maria with Anna and Louis II, children of Vladislaus II of Hungary and Bohemia.

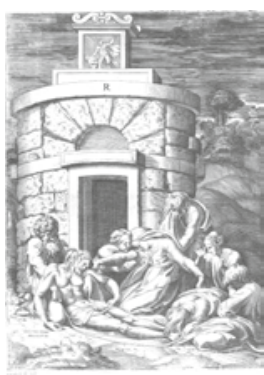

FIGURES 13.7-13.10
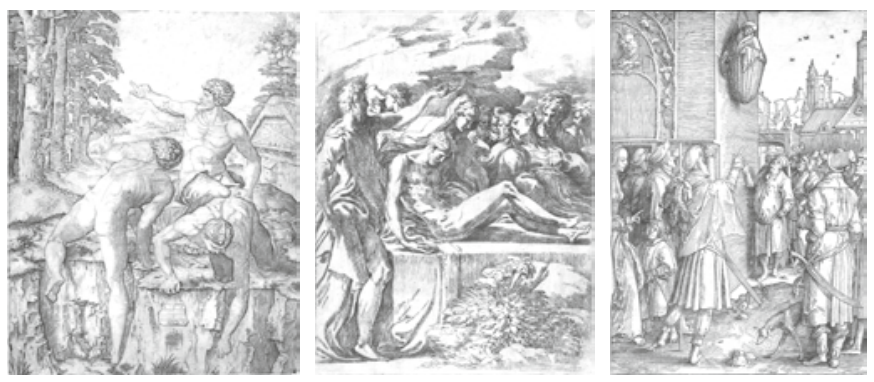

Examples of the type of material in Strada's print collection: Enea Vico, Lamentation, engraving after a design by Raphael; Marcantonio Raimondi, Nude soldiers, after a detail of Michelangelo's Battle of Cascina, engraving; Parmigianino, Entombment, etching; Lucas van Leyden, Virgil suspended in a basket, 1525, engraving.

The volume of prints mostly by and after Italian masters, but also including prints by Lucas van Leyden, functioned as a pendant volume to the Dürer album both in its make-up and in its contents. Figures 13.7-13.10 give an impression of the type of material it will have included: prints after the most famous works by Raphael, Michelangelo and other great masters by engravers such as Marcantonio Raimondi, as well as some original etchings by Parmigianino and the famous woodcuts by Lucas van Leyden. Together the two albums provided a splendid survey not only of the graphic arts as such, but also of the pictorial inventions of both the Italian and the Northern Renaissance. Strada must have brought these prints together during his many travels, but in particular during his sojourn in Rome in the 1550 s and his trips to Venice in the 1550 and the 1560 . 
We have no concrete information on other prints in Strada's collection, but it is clear that these two volumes represent only a small—though perhaps the most prestigious-part of his graphic possessions. Through his trips and his regular contacts with the international book trade he could easily obtain the products of famous publishing houses such as those of Salamanca in Rome and Hieronymus Cock in Antwerp. Just like his old acquaintance Samuel Quiccheberg, who explicitly stressed the importance of prints in his 1565 treatise, Inscriptiones vel tituli theatri amplissmi, which provides a blueprint for the ideal, universal museum, Strada valued them not only for their artistic qualities, but also - and perhaps more - for their function as bearers of information. ${ }^{26}$

\subsubsection{The Drawings}

It is clear that the volumes of drawings mentioned in Ottavio's correspondence likewise comprised only a part - though possibly the most prestigious — of Jacopo's collection of drawings: the architectural drawings, for instance, to which Strada explicitly refers in his preface to Serlio's Settimo Libro, are not included. Presumably these were kept in separate volumes, such as that containing Giulio's vase designs offered to the Grand Duke. At present it is not possible to determine of what separate sections Strada's collection was constituted, but a closer examination of the problem of the 'copies' Ottavio sent to Florence, provides some additional information relative to the actual contents of some of these sections.

At first sight this problem appears to defy solution. Should one accept that the drawings sent to Florence had been in fact, as Ottavio Strada claimed, the autographs of some of the most famous artists of the Renaissance, one would have to admit that such Florentine connoisseurs as Niccolò Gaddi would not have recognized them as such, which is a rather unlikely supposition. Supposing on the other hand that the drawings had been copies or even forgeries of original autograph drawings, one would have to suppose either that Strada himself was fooled when he acquired the drawings, or that he or his son had executed these copies or forgeries himself. In view of Strada's artistic training and general erudition, and of the fact that he bought most of the material immediately from the heirs of Perino and Giulio, both of whom he had well known personally, the first proposition is extremely improbable. Though the second proposition may seem less unlikely — autograph drawings of the most famous masters already were coveted collector's items, and occasionally very deceptive copies or interpretations are found, such as the famous PseudoLeonardo at the Albertina [Fig. 13.11] —it is questionable whether deliberate

26 On Quiccheberg, see Quiccheberg/Roth, 200o; and earlier Belsiger 1971; Falguières 1992; Jansen 1993 . 
forgery on such a large scale, involving hundreds of drawings, was practiced in the sixteenth century. ${ }^{27} \mathrm{It}$ is equally improbable that Ottavio, whose dismay at the reaction from Florence sounds rather sincere, would have mistaken studiocopies from his father's workshop, which were intended to be bound in the libri di disegni the Stradas purveyed to their patrons, for the real thing. Even had he not known that such copies of his father's autographs had been made, he still would have easily recognized them, since they were never made to reproduce in detail the personal 'handwriting' of an individual artist, but merely served to record a given pictorial 'invention', for instance the copies of Giulio Romano's drawings discussed and illustrated below [Ch. 13.6.4].

Fortunately an attentive reading of Armenini allows us to formulate a hypothesis that neatly solves this apparent paradox, and explains how Ottavio could rightly insist on the provenance of the drawings he sent to Florence, while at the same time Gaddi and his colleagues were not mistaken in considering them to be copies. Discussing Perino del Vaga's technique, Armenini described that when he lived in Strada's house in Rome he was allowed to study the many copies, or rather reinterpretations, that Perino had produced of great part of the work of Raphael and of some of the ignudi of Michelangelo's Last Judgment, together with a quantity of sketches '<...> adapted from many print designs which were inventions of Italian and of German [artists], and drawings after the Antique. In these chalk drawings Perino had his models '<...> with such art reduced to his own sweet manner<...>' that it was difficult even for the expert to see where he had found his inspiration..$^{28} \mathrm{~A}$ beautiful

27 Albertina, inv. nr 6or;; Wickhof 1892, SR 72; Birke/Kertész 1992-1997, p. 33. On the basis of an inscription on the back, this particular copy of a Leonardo original which presumably was in Rudolf II's collection is attributed to Jacob Hoefnagel: Th. Wilberg-Vignau:Jacob Hoefnagel: Ungleiches Paar in einer Landschaftsumrahmung, inv.nr. 6or. (Albertina OnLine, http://sammlungenonline.albertina.at/\#fa6fdee7-786f-4730-a7d3-9d7c577o6boo, consulted 07-01-2013).

28 Armenini 1587, p. 64-65, speaking of Perino's drawings Strada allowed him to study: '<...> dove che fra l'altre cose belle, io vidi di sua man propria una gran parte dell'opera ch'havea dipinte Raffaello, già suo maestro; le quali erano dissegnate di lapis nero et alcuni ignudi del giuditio, i quali dissegni si vedevano essere con tal' arte ridotti alla sua dolce maniera, che si potea dir più tosto quelli esser da lui nati, e trovati, che ritratti da altrui; e non era solamente questi ch'io dico, ma vi erano ancora di molti schizzi cavati da più dissegni di stampe, ch'erano inventione d'Italiani, et di Tedeschi, sì come ci era ancora un numero infinito di pilli, di partimenti, di statue, di grottesche, pur cavate dalle antiche, con altre cose tali, che sono sparse, et occulte per Roma, et non ignote à noi, dove che esso nel ritrarle, le veniva tuttavia mutando quando una cosa, et quando un'altra, et a quelle ch'erano rotte, ò non molto gagliarde, gli aggiungeva, li levava, et le arrichiva, et in somma le riduceva in modo tale, con quella sua leggiadra maniera, ch'era cosa difficile da' ben prattichi à conoscere di dove egli cavate le havesse ....' 

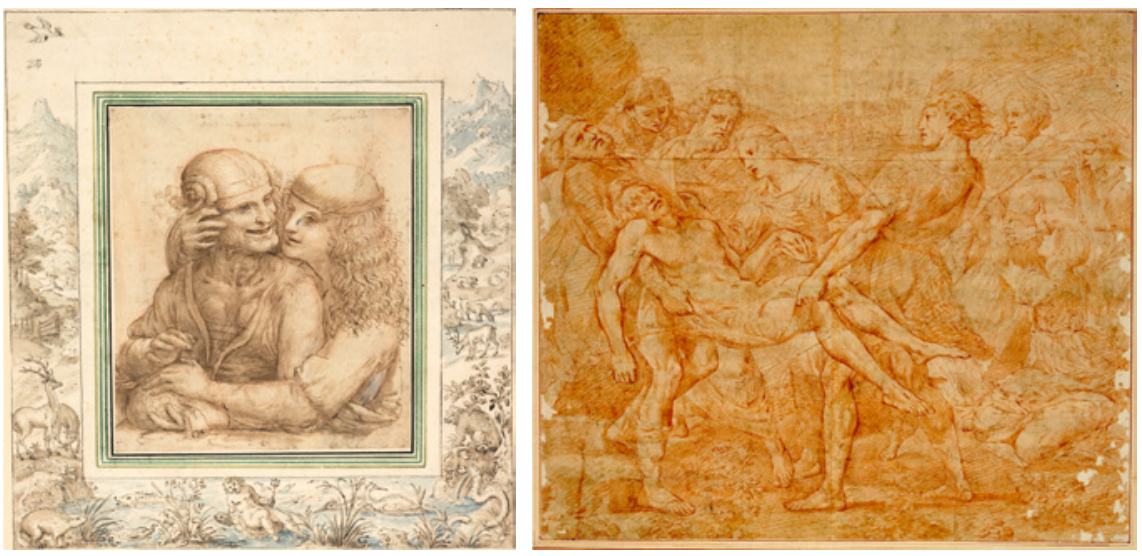

FIGURE 13.11

Attributed to Jacob Hoefnagel, after Leonardo da Vinci, Unequal affection; the frame by an anonymous draughtsman; Vienna, Albertina.

FIGURE 13.12 Perino del Vaga(?), Entombment, after Raphael's Pala Baglione. Vienna, Albertina.

anonymous drawing in red-chalk in the Albertina, which copies Raphael's Entombment now in the Galleria Borghese, was attributed to Perino in the past, and well illustrates the quality and refinement that such copies could attain to [Fig. 13.12]. ${ }^{29}$

The consignment of drawings that Ottavio sent to the Grand Duke must have largely consisted of similar drawings after well-known works of art in Rome and after prints. Though Strada himself of course had been perfectly aware of the origin of this part of his collection, Ottavio seems never to have visited Rome or Florence, and in consequence he was apparently unable to distinguish between these reinterpretations and the original work..$^{30}$ Niccolò Gaddi was much better versed in the art of his century than Ottavio, and immediately recognized the sources of the drawings. Though he presumably would have appreciated an autograph study for the School of Athens or the Creation of Adam, to give some random examples, he obviously had little interest in another set of copies after these well-known 'inventions'. After all he did not

29 Albertina, inv. nr. 14205; cf. Wickhof 1892, pp. SR 521; Birke/ Kertész 19952-1997, 3, p. $185^{1}$ (http://sammlungenonline.albertina.at/?query $=$ Inventarnummer $=[14205] \&$ showtype $=r$ ecord ). The drawing is now not attributed. Of course the possibility remains that Perino's Nachlass as acquired by Strada from his widow, also included drawings by Perino's assistants and pupils, whom he may have trained by having them make similar copies themselves.

30 Ottavio had lived in Rome as a child, and had accompanied his father to Venice, Verona and Mantua in the late 1560 s, but there is no evidence that he ever visited Italy later in life. 
know that, though Ottavio's drawings obviously were not autograph Raphael or Michelangelo, they were at least autograph Perino del Vaga. ${ }^{31}$

If this interpretation of the available data is correct, it is possible to conclude that Jacopo Strada had kept Perino's copies-or 'Contrafactur', according to Strada's will—together as a separate entity until they were carried off by Ottavio, and he will have ordered the rest of his collection in similar coherent groups. The album of three hundred drawings which Ottavio offered to Prospero Visconti thus must have made part of the section of autograph figure drawings, while the architectural and ornamental designs constituted further sections, the latter including Giulio's designs for goldsmith's work and probably also for costume, armour and ephemeral decoration for jousts, masques and other courtly festivities. The few identifiable remains from Jacopo Strada's Musaeum that have remained intact consist of rather more heterogeneous material, and their contents suggest that relative quality also played some role in the ordering of the drawings. ${ }^{32}$

Unfortunately the data do not permit to decide whether those groups that Ottavio offered in bound albums - that is the prints, the Italian autograph drawings, and Giulio's 'invenzioni stravaganti'-represented selections made by himself, concerned to split up the material in easily negotiable items, or that they already had been put together in this form by his father. This latter option is not improbable in view of the manner in which Giorgio Vasari had ordered one of the few contemporary collections of drawings of comparable dimensions, his famous Libro de' disegni. This Libro in fact consisted of several volumes, and the drawings contained in each of these had been mounted in splendidly decorated passe-partouts. It remains unclear whether these mounted sheets were actually fixed in the bindings, or could be shuffled around at will. That this second technique was not unusual is suggested by the wording of the descriptions of similar volumes of drawings in the inventory of a slightly later collection, that of the Emperor Rudolf II, and of the presence in his Kunstkammer of 'a big book [bound] in parchment [consisting] purely of blank paper of folio reale size, in which it is possible to keep all sorts of Disegni'. ${ }^{33}$ On the other hand the relics from Strada's Musaeum show that at

31 On Niccolò Gaddi, see Arrighi 1998.

32 Vienna, ÖNB-HS, Cod. Min. 21,3 includes, apart from copies from Strada's workshop, some individual items; the codex preserved in the library of the Strahov Monastery in Prague, ms. DL III 3, contains miscellaneous decorative designs and sketches mostly by and after Giulio Romano, and including some copies made in Strada's workshop; cf. below, pp. Ch. 13.6.

33 Bauer/Haupt 1976, p. 139, nr 2799: 'ein gross Buch in pergamen von lautter Ledigen regalpapir darein man allerhand Disegni legen kan'. 
least occasionally he had pasted certain drawings onto sheets belonging to or intended for a bound album. ${ }^{34}$

\subsection{Later Fate of Strada's Prints and Drawings}

Ottavio Strada's attempts to sell prints and drawings from his father's collection to the Grand Duke of Tuscany were unsuccessful; perhaps archival research in future may unearth further evidence of comparable transactions. What is striking is Ottavio's reluctance to sell to his own patron, the noted amateur, connoisseur and passionate collector of art, Emperor Rudolf II. Perhaps because of Ottavio's position as Rudolf's trusted antiquary — and moreover as the father of Anna Maria, his illegitimate daughter who was the Emperor's mistress and the mother of some of his children - he was too well aware of the difficulties he would have actually to collect payment for the objects he provided. Nevertheless it may not always have been quite so easy to find suitable buyers for the drawings as Ottavio suggests in one of his letters to the Grand Duke, and in any case his position as a Gentleman of the Household and official Antiquary to the Emperor would not allow him to thwart Rudolf's express desires. In fact his contributions to the Imperial collections have not been inconsiderable, as the inventory of 1607 makes clear. This inventory includes a list of the illustrated books and manuscripts and of the volumes of prints and drawings that constituted a special section of the Kunstkammer. Besides at least eight examples of libri di disegni that were the fruit of Ottavio's own industry, this list includes a number of items the description of which corresponds to objects known to have been in Jacopo's Musaeum. ${ }^{35}$

Unfortunately, though the remains of Strada's collection constituted the obvious source for graphic material of Italian origin in Prague, and consequently a considerable portion of it must have found its way into Rudolf's collection, the groups of Italian drawings listed in the Inventory are so concisely described that even a merely tentative identification with items mentioned in Ottavio's correspondence is possible only in very few cases. Apart from an album of prints by Dürer and a similar volume of prints by various Italian masters, which may or may not have been identical with the book of prints Ottavio had offered to Prospero Visconti, two items are of special interest in this context. These volumes are described as follows:

34 Such as the Strahov codex (cf. below).

35 The inventory is published in Bauer/Haupt 1976. 
2686. Another big book of folio reale size paper, bound in old, reused ['verschriben'] parchment [i.e. the parchment used consisted of old letters or pages from an abandoned manuscript], in it mostly things and drawings in red and black chalk, after Michael Angelo Bonar: and other excellent men ['valent homini']

2694. A big and fat book bound in parchment in folio reale size, in it only hand drawings by the most important Italian masters. ${ }^{36}$

Item 2686 can with some confidence be identified with either the whole, or with a portion - in that case the larger sheets - of the consignment of drawings that Ottavio had sent to Florence in 1590, this both because of its contentscopies after Michelangelo and other masters, rather than drawings by their own hand - and because of the use of the term 'valent homini', echoing Ottavio's description, in the German text of the inventory. Possibly this term was derived from a label or title page added when the material—which can perhaps be attributed to Perino del Vaga, as we have seen-was put together in a cheap binding of re-used vellum, either before or shortly after Ottavio ceded it to the Emperor. Item 2694, a large-size and bulky volume of drawings by important Italian artists, may well have been identical with the volume containing three hundred autograph drawings that Ottavio had offered to Prospero Visconti in November 1590.

Finally it is rather probable that the 'Inventioni stravaganti per fare una credenza di un gran Principe' attributed to Giulio Romano, which Ottavio offered, but never actually sent to the Grand Duke, was identical with any one of the volumes containing drawings of 'vasi in penna' that are listed in the inventory. ${ }^{37}$ This may have been the codex that is still preserved intact in the library of the Strahov Monastery at Prague, as has been suggested by Beket Bukovinská, Eliška Fučíková and Lubomír Konečný in their integral publication of the album. The Strahov Codex contains a number of autograph designs for goldsmith work by Giulio and his school, but it also includes a number of copies of similar inventions executed in Strada's own workshop, and a quantity of miscellaneous odds and ends: it constitutes an interesting and rare relic of Strada's Musaeum, and will be discussed below. It is, however, more likely that Ottavio offered a more splendid volume to the Grand Duke, consisting exclusively of

36 Bauer/Haupt 1976, p. 134: '2686. Ein ander gross buch von regalbogen in schlecht verschriben pergamen copert gebunden, darin mehrerteils sachen und zaichnus mit rot und schwartzer kreiden, nach Michael Angelo Bonar: und anderer valent homini' and p. 135: '2694. Ein gross dickh in pergamen gebunden buch in regalgröss, darin lautter von den fürnembsten italienischen maistern handriss'. 
Giulio's own designs for elaborate goldsmith work that since have been dispersed, and have found their way to half a dozen print rooms across Europe and the United States. ${ }^{38}$

\subsection{Drawings Preserved in a Context Linking Them with Strada}

By the early seventeenth century collectors and perhaps dealers in drawings began to use collector's marks, written initials or symbols, or little stamps placed on each sheet. Unfortunately in Strada's day this admirable custom had not yet been thought of, and since he did only rarely scribble any attributions, explanations or remarks onto the sheets in his possession, it is possible to identify individual sheets that passed through his hands in only a few cases. Strada's collection of drawings was almost entirely dispersed in the decades after his death, and may have furnished material for the cabinets of many famous collectors of the seventeenth century, such as Paul von Praun, the Earl of Arundel and Everard Jabach. ${ }^{39}$ In the process most of the albums containing his collection of original drawings were cut up, but fortunately two volumes survived more or less in their original form, both in Prague, and provide at least some concrete information about the contents of the Musaeum.

\subsubsection{The Strahov Album}

The codex preserved in the library of the Strahov Monastery is the most important of these. A cut-out engraving of Ottavio Strada's coat-of-arms pasted onto its title-page functions as an ex-libris, and demonstrates its provenance from Strada's Musaeum. ${ }^{40}$ The binding in white leather is decorated with impressed portraits of Charles V and the Elector of Saxony, and appears to date from the 1570s. The codex itself consists of about eighty-five sheets of a paper produced in Prague. Since these sheets where unmarked when they were bound,

38 Cf. Ugo Bazzotti in Giulio Romano 1989, pp. 454-457.

39 Later references in archival sources provide tantalizing hints about the possible later fate both of the volumes in Rudolf's collection and of other graphic material from Strada's Musaeum.

40 Prague, Strahov Monastery, Library, DL III 3, Selectarum inventionum collectanum ex diversis auctoribus; a cut-out of Ottavio Strada's coat of arms pasted onto the title page confirms its provenance from the Stradas' workshop. This discussion is based on the splendid, integral edition of the codex by Beket Bukovinská, Eliška Fučíková and Lubomír Konečný (Bukovinská/ Fučíková/ Konečný 1984). Apart from this fundamental work, their personal interest, their hospitality and counsel during several visits to Prague have been invaluable for my research. 
the volume's initial function must have been akin to those found in Rudolf's Kunstkammer, as cited above: 'ein gross Buch in pergamen von lautter Ledigen regalpapir darein man allerhand Disegni legen kan'. In this case, however, the 'disegni' were pasted onto the sheets of the album, and this content is specified on the rather carelessly executed title-page as 'Selectarum inventionum ex diversis auctoribus'.

The album is filled with cut-out designs of which a considerable part can be attributed to Giulio himself, and a number of related designs are attributable to Giulio's circle [Figs. 13.13-13.19]. These are complemented with pen-and-ink copies of Giulio's designs - some of them actually copied from autographs contained in the volume itself - that were produced in Strada's workshop, and with some miscellaneous material of various origins (including some architectural drawings, none of which appear to be linked with Mantua). Many of the autograph drawings can moreover be linked to similar copies preserved in libri di disegni produced by the Stradas, while some of the copies in the Strahov codex appear reproduced from autograph designs by Giulio preserved elsewhere. ${ }^{41}$

From the copies of Giulio's designs for goldsmith work included in the volume and in several other libri di disegni produced in Strada's workshop, it is evident that he possessed many more of Giulio's designs besides those pasted into the Strahov codex. This suggests that the Strahov volume represent a selection - or rather a de-selection - from the material he had available; its miscellaneous contents suggests that the album should be considered as part of the rebut, remnants that either were duplicates—of many of Giulio's several
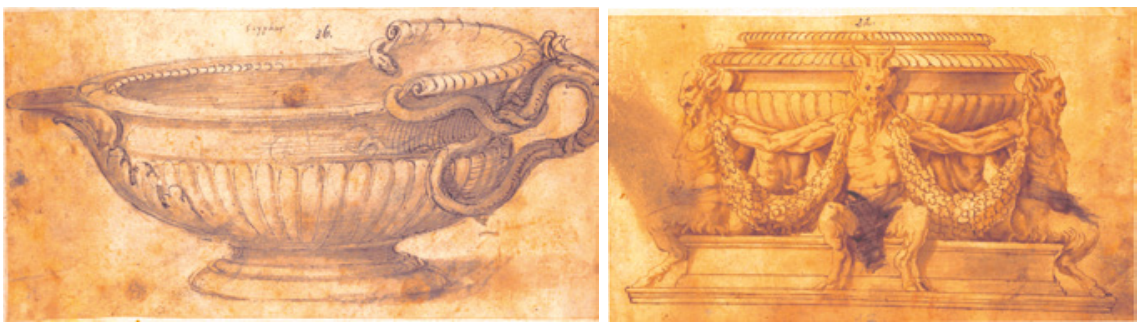

FIGURE 13.13 Strahov codex, fol. 28/36: Giulio Romano, autograph design for a ewer.

FIGURE 13.14 Strahov codex, fol. 17/22: Giulio Romano or workshop, design for a salt cellar.

41 Valerie Taylor is at present undertaking a careful comparison of the several albums of such drawings, mostly executed by Ottavio Strada, and attempting an identification of the sources of the individual designs-besides Giulio these includes similar designs by Francesco Salviati. 

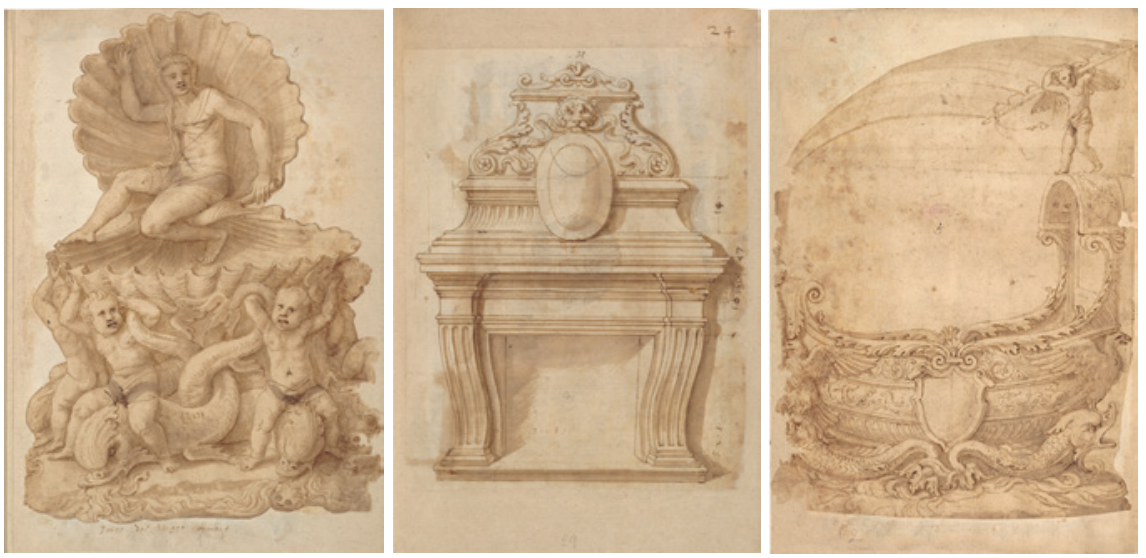

FIGURE 13.15 Strahov codex, fol. 1/1: Giulo Romano or workshop, design for a saltcellar.

FIGURE 13.16 Strahov codex, fol. 29/38: Workshop of Giulio Romano, design for a chimneypiece.

FIGURE 13.17 Strahov codex, fol. 2/2: Giulio Romano, design for a princely cradle.

autographs variant versions and/or workshop copies exist-or were deemed of insufficient quality to be included in the better organized volumes consisting exclusively of first-rate sheets that made up Strada's Musaeum, and that for that very reason have since been cut up and dispersed.

Nonetheless the Strahov codex contains the largest body of autograph drawings by Giulio Romano we possess; it is of the utmost importance for our understanding of his style as a designer of decorative objects, in the first place of vases and other objects of goldsmith work, but also of several chimneypieces [Fig. 13.16], a princely cradle [Fig. 13.17] and two beds (fols. 49 and 52), and a wall tomb or monument [Fig. 13.18]. In view of Strada's involvement with the tombs of the Emperor Maximilian I in Innsbruck and of Ferdinand I in Prague, a beautiful design for the tomb of Francesco II Gonzaga is particularly interesting [Fig. 13.19], though its attribution to Giulio is problematical. ${ }^{42}$ Over all

42 The tomb Federico Gonzaga planned to erect for his father was an important project initiated in 1519 by a design by Raphael; a later, simplified version was probably designed by Giulio; its execution was entrusted to Alfonso Lombardi Cittadella, at whose death the project had hardly been begun; in the end it was never realized. The Strahov codex includes two further copies of variant designs for this tomb (fol. 142/250 and 152/260), the former a copy of the drawing in the Louvre (Cabinet des Dessins inv.nr. 3576). Another variant is preserved in Munich (Staatliche Gaphische Sammlung, inv.nr. 5006); Bukovinská c.s. attribute none of these designs to Giulio, whereas Amedeo Belluzi, 'Il progetto per il monumento a Francesco II Gonzaga', in Giulio Romano 1989, pp. 558-56o, does give them to Giulio. 

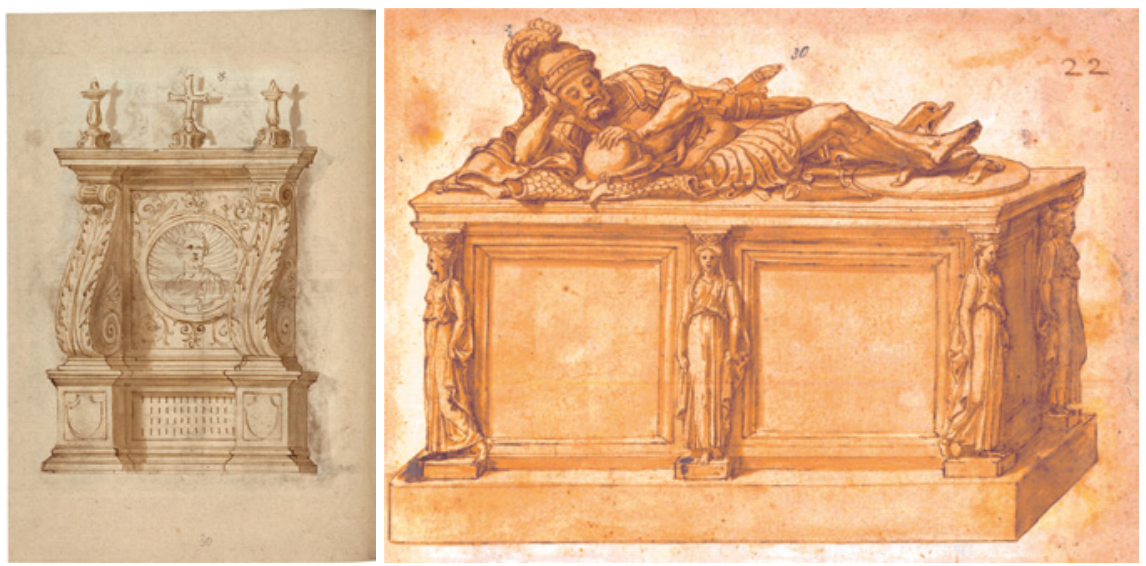

FIGURE 13.18 Strahov codex, fol. 30/39: Giulio Romano, design for a wall tomb.

FIGURE 13.19 Strahov codex, fol. 25/30: after Giulio Romano?, design for the tomb of Francesco II Gonzaga.

the Strahov codex well demonstrates the interest that Giulio's works aroused among his own contemporaries.

At the end of the volume some material is included that had nothing do with Giulio: a number of ground plans of Italian churches, the plan of a palace and a plan and section of what is probably (a reconstruction of) an ancient Roman building [fol. 157/266; Fig. 13.20]. Its carefully executed hatchings show it to be a design prepared for the (wood)engraver-the sheet is squared for transfer-which relates this latter drawing to the Serlio treatise, perhaps even to that master himself. On the other hand the partly lost annotation in the right corner seems a later addition: the handwriting suggest that it is Strada himself who noted how much of this reconstructed Roman ruin was still actually standing: 'from the outside $<\ldots>$ all ruined' 43

The other four architectural drawings seem all later, and appear to be drawn in the same hand. They represent the plans of a Renaissance palace [fol. 159/268; Fig. 13.21] and of three churches, the cathedrals of Pisa [fol. 155/264; Fig. 13.22] and of Florence [fol. 158/267; Fig. 13.23], and Brunelleschi's church of San Lorenzo in the latter city [fol. 156/265; Fig. 13.24]. These plans are simple

43 Bukovinská/Fučíková/Konečný 1984, p. 182, cat. nr. 157/266 (as ‘Querschnitt und Grundriß einer Kirche'): 'di fuori si fà [word cut off] / tutto ruinato'. It is conceivable that during his 1554-55 visit to Rome Strada would have compared his newly acquired documentation of Roman monuments with their remains. I have not yet identified the building; which looks like a section of a thermal complex or a residential palace, rather than a temple. Its image is not included in the published Serlio volumes. 

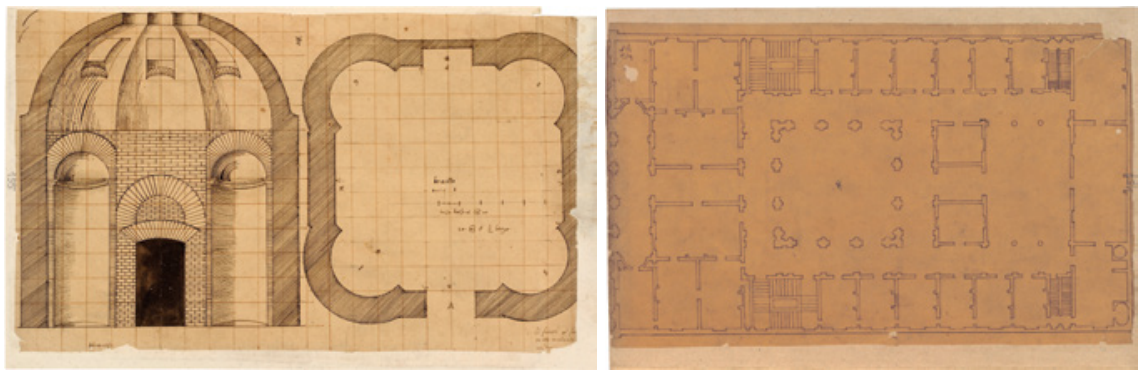

FIGURE 13.20 Strahov codex, fol. 157/266: section and plan of (part of) a Roman bathhouse. FIGURE 13.21 Strahov codex, fol. 159/268: plan of an Italian palace.
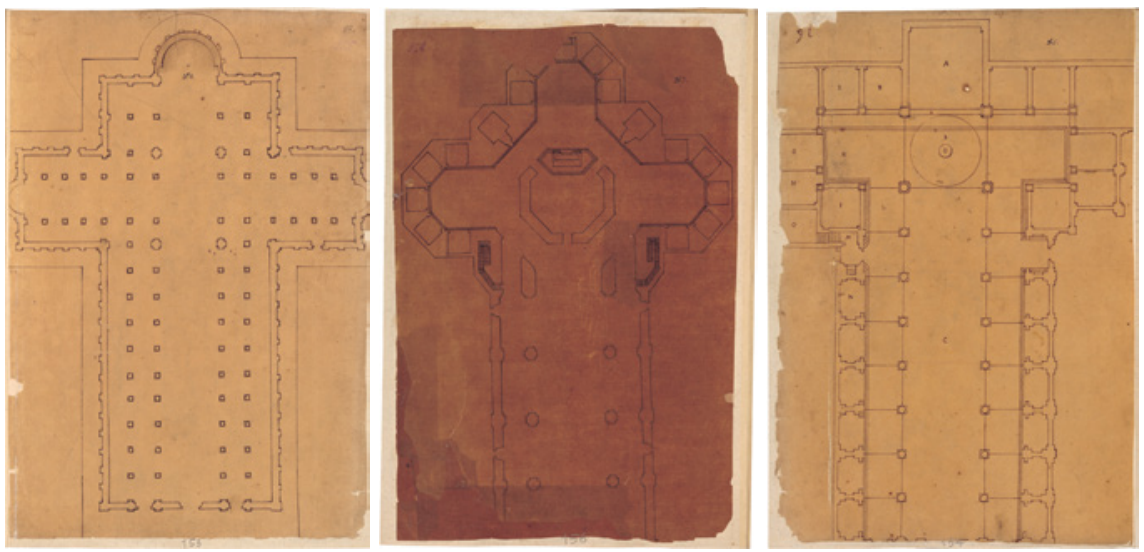

FIGURES 13.22-13.24

Strahov Codex, fol. 155/264: plan of Pisa Cathedral; fol. 158/267: plan of Florence Cathedral; fol. 156/265: plan of San Lorenzo, Florence.

and not very detailed, but they are carefully drawn, and provide documentation that is quite clear and easily readable even for a layman. ${ }^{44}$

\subsubsection{The Codex Chlumczansky}

It is very likely that another codex preserved in Prague, ms. XVII A6 of the library of the National Museum in Prague, made part of Strada's purchase from Raffaello Pippi. It has been catalogued in detail by Vladimír Juřen, who baptized it the Codex Chlumczansky, after a later owner, Václav Leopold Chlumčanský

44 Bukovinská/Fučíková/Konečný 1984 do not identify these plans: p. 182, cat. nrs. 155/264 (Pisa, Duomo); 155/265 (Florence, San Lorenzo); 158/266 'Grundriss einer Kirche', cf. the preceding note; $155 / 267$ (Florence, Santa Maria del Fiore); 155/268 (contemporary palace design which I have not as yet succeeded to identify). 

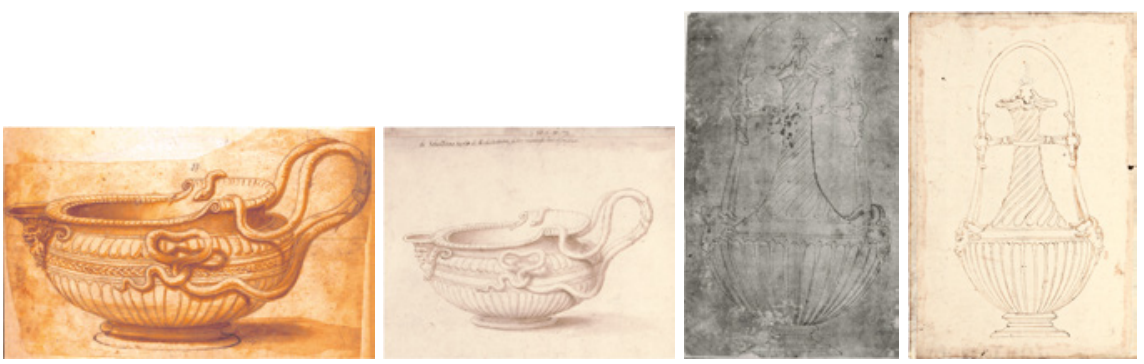

FIGURE 13.25 Strahov codex, fol. 28/37: anonymous design for a ewer, after Giulio Romano,with autograph corrections.

FIGURE 13.26 Codex Chlumczansky, inside of front board: copy of design for a ewer by Giulio Romano.

FIGURE 13.27 Strahov codex, fol. 28/37: copy of a design for a double-handled vase, after Giulio Romano.

FIGURE 13.28 Codex Chlumczansky, fol. 4V., copy of a design for a double-handled vase, after Giulio Romano.

z Přestavlk a Chlumčan, Archbishop of Prague since 1815 (1749-1830).45 The provenance of this album from Mantua is borne out by Federigo Gonzaga's impresa impressed on its binding, by some entries (such as a variant reading of the epitaphs of Baldassare Castiglione and his wife, and that of the Mantuan nobleman Giovanni Cattaneo ( $\dagger 1541)$, as well as by the Mantuan origins of many of the drawings later added to the album.

Though its provenance from Strada's Musaeum cannot be established beyond all doubt, it is a virtual certainty not only because of its Mantuan antecedents, but also in view of the copy of a design for a vase by Giulio Romano pasted onto the title page, which is similar to one found in the codex from Strahov, and which is accompanied by a title referring the volume to Sebastiano Serlio: 'di Sebastiano Serlio di Architectura liber manupictus et scriptus'. Such an unusual combination would hardly have been found anywhere else but in Strada's Musaeum, and the title was probably added by someone who was well aware of the various components of Strada's collection, but was not

45 Prague, National Museum, Library, ms. XvII A 6; Album, 44 x 29 cm, containing 97 sheets, a number of later additions mostly pasted unto blank pages; sixteenth-century Italian binding bearing the imprese [Fides and Olympos] of Federigo Gonzaga, Duke of Mantua; interior front cover carries a ms. title: 'di Sebastiano Serlio di Architectura liber manupictus et scriptus'. The album is integrally published in Juřen 1986, which is summarized in the following description; a brief description in Giulio Romano 1989, p.332 and Figs. on pp. 47,320 . 
able to distinguish between them. ${ }^{46}$ Certainly the material it contained seems very close to the type of material we know Strada to have collected and to have used as raw material for his own projects.

The original nucleus of the album consists of over $35^{\circ}$ antique inscriptions, mostly Latin and some Greek, from Rome and other regions of Italy, from Nîmes, from Vienna and from Spain and Portugal, most of which were copied from other similar collections [Fig. 13.29 and 13.40, top], and of some 150 architectural drawings. These drawings were copied for the greater part from models not antedating the end of the fifteenth century [Fig. 13.30], and they include some that can be linked to the circle of Giuliano da Sangallo [fols. 7ov-71, Fig. 13.31: idealized views of the Pantheon and its interior; fol. 85, Fig. 13.32, top left: elevation and plan of the Basilica Aemilia]. The paper of this section of the album suggests that its first owner came from Northern Italy, probably the Veneto.

Only the later additions, which are either pasted unto or directly entered onto the pages that had remained unused, unequivocally link the album to Giulio Romano's Mantuan circle. The following elements are of particular interest:

Drawings:

- A group of twelve plans of ten modern buildings [fols. 1-2, Figs. 13.33-13.34; fols. 5, 93, 9597, Z; two repeats]; most of these are identical to drawings in the so-called 'Mantuan Sketchbook' in Maarten van Heemskerck's Berlin albums: these latter are regarded to have been copied from Giulio Romano's projects by the so-called 'Anonymous A', a presumably Northern draughtsman who visited Mantua sometime between $1540-155^{\circ}$ and has been tentatively identified with the Dutch painter Hermannus Posthumus. ${ }^{47}$

$46 \quad$ The hand is late sixteenth century; it appears not to be Ottavio Strada's, but might be Paolo's. A provenance of the album and/or part of its contents from Serlio's collection should not be totally excluded-Serlio seems to have known Giulio personally (cf. Frommel 2002, p. 66 and 80, notes $150-15^{2}$ ) and he might have received it as gift from Giulio, or even from Federico Gonzaga himself; but this stretches the available evidence further than the assumption that Strada had acquired the album sometime in Mantua, and had later used its empty pages to archive other materials from his collection. The arguments against a provenance from Strada's studio advanced in Juřen 1986 (pp. 118-119) are not very forceful: that it is not included in the Index sive catalogus is perfectly understandable, because that is not an inventory of Strada's collection, but a list of manuscripts Strada considered ready for the press; and that the Spanish inscriptions included in it were not used as a source for those he added to his 1575 edition of Caesar's Commentaries can be explained by the fact that he must have possessed many other syllogae of Spanish epigraphic material, in part perhaps obtained though his connection with Antonio Agustín, which he may have considered more reliable.

47 The foliation of the codex are given as in Juřen 1986, whose attributions are generally followed; on the Anonymous A, cf. Hülsen/Egger 190o, II, ff. 13, 13V, 29v, 58, 73v; Dacos 1989. 


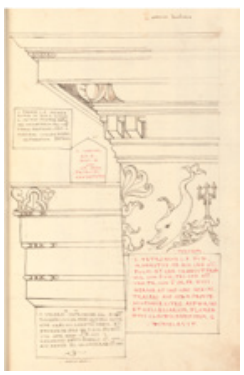

FIGURES 13.29-13.31
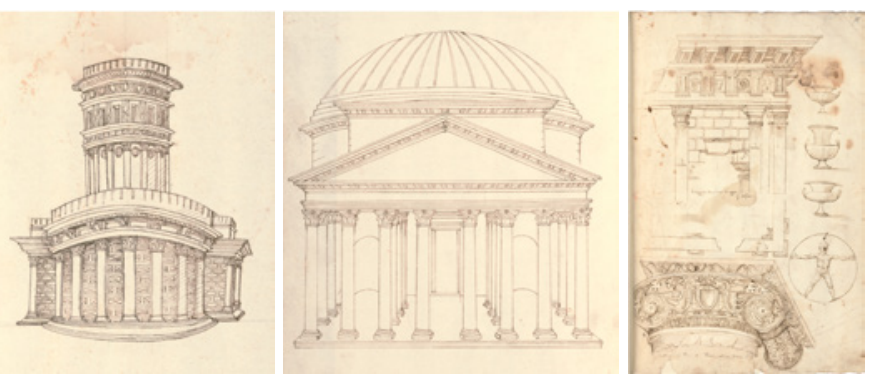

Codex Chlumczansky, fols. 26r., 70v., and 85r.: examples of the original contents of the album: inscriptions, architectural elements and copies of reconstructions of ancient Roman monuments, including the Pantheon.

FIGURE 13.32

Codex Chlumczansky, fol. 85 r.: a study of plan and elevation of the Basilica Aemilia in the Forum Romanum, surrounded by later additions (vase designs after Giulio Romano, a representation of the Vitruvian figure and a study of a Ionic capital).

- A view of a cupola and a plan and of a worked out variant of a centralizing chapel very similar to the Chapel of the Holy Sacrament in Mantua Cathedral, reconstruction of which was planned by Giulio in 1545 [fol. 62v.; Figs. 13.35-13.36].

- A view of the elevation of the east façade of the courtyard of the Palazzo del Te at Mantua [fol. 2v; Fig. 13.37]. The slight differences between the drawing and the façade as executed indicate that the Prague drawing is based on one of Giulio's preparatory designs, which had likewise been the source for a similar drawing by the 'Anonymous A'.48

- Two drawings [fols. Ad and 4v], copying Giulio's designs for vases, copies of which can be found also in the Strahov codex [Figs. 13.25-13.26 and 13 27-13.28].

- An anonymous, unfinished design for a fountain, a variant of type dating back to the fifteenth century [fol. 3v.; Fig. 13.38]

- An anonymous drawing and a careful transcription of the inscriptions of the tomb of Petrarch at Arquà Petrarca, probably antedating 1547, when a bust and a commemorative plaque were added to it. It is interesting in being the earliest known image of Petrarch's tomb [fol. 5r.; Fig. 13.39].

One of the drawings (fol 2r.) is thought to be by Giulio Romano, cf. Paul Davis and David Hemsoll, 'Ville e corti', in Giulio Romano 1989, pp. 517-519. 

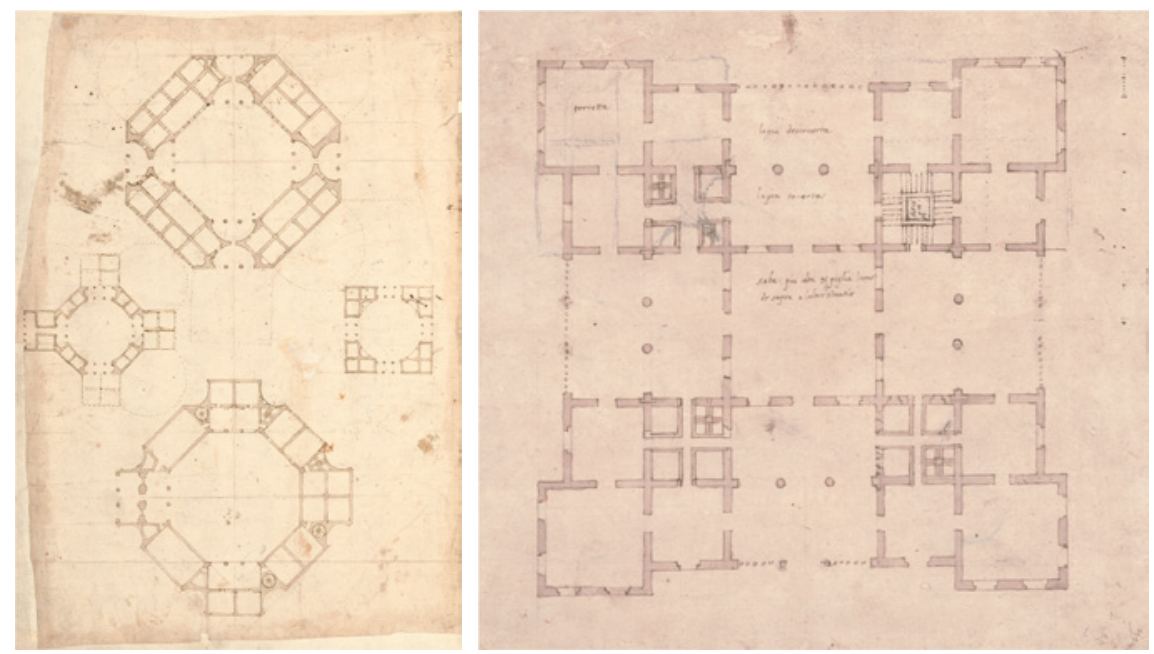

FIGURE 13.33 Codex Chlumczansky, fol. 1v.: several plans of centralized buildings.

FIGURE 13.34 Codex Chlumczansky, fol. 2r.: a plan for a villa of the Poggio Reale type.
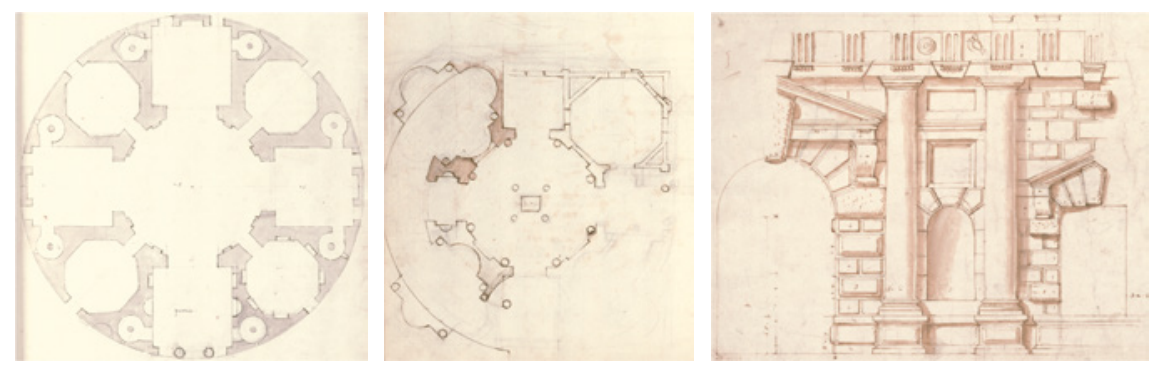

FIGURES 13.35-13.36 Codex Chlumczansky, fols. 96r. and 62v.: two versions of a plan of a centralized church, possibly copies after studies by Giulio Romano for the Chapel of the Holy Sacrament in Mantua Cathedral.

FIGURE 13.37

Codex Chlumczansky, fol. 2v.: (after?) Giulio Romano, study for the east façade of the courtyard of the Palazzo del Te.

Texts:

- Alternative versions of the epitaphs originally composed by Pietro Bembo for Baldassare Castiglione and his wife, Ippolita Torelli [Fig. 15.39, bottom]. This tomb was erected in the sanctuary of Santa Maria delle Grazie in the Mantuan suburb of Curtatone in the late 1520s; it was designed by Giulio 

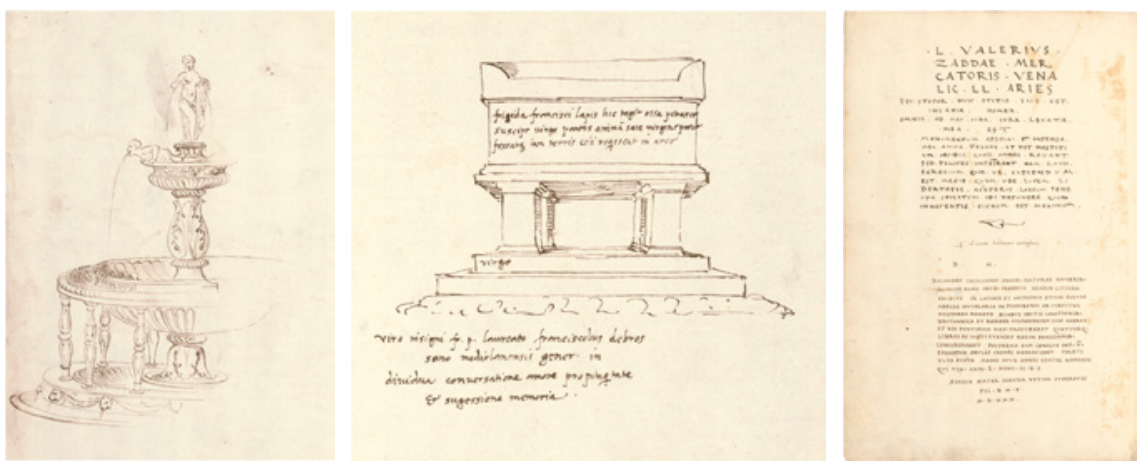

Codex Chlumczansky, fol. 3v.: anonymous design for a fountain; fol. 5 r.: anonymous, documentary drawing of the tomb of Petrarch at Arquà Petrarca and its inscriptions; fol. 12v., top: transcription of a classical inscription (original album); bottom: addition, transcription of the epitaph for the tomb of Baldassare Castiglione in Santa Maria delle Grazie near Mantua.

Romano, in accordance with Castiglione's will of 1523 . It should be noted that the same church housed the tomb of Jacopo Strada's granduncle. ${ }^{49}$

- An inscription which was not realized or has disappeared, intended as an epitaph for the funerary chapel of some 'Benefactor of the Holy Blood', and which in the codex is attributed to the Mantuan court poet Benedetto Lampridio [fol. 25v]. It can be linked to the chapel of Isabella Boschetto in Sant'Andrea, in which were buried the remains of Saint Longinus: the drops of Christ's blood caught up by this Roman soldier at the Crucifixion constituted Mantua's most precious relic. The decoration of the chapel was commissioned by Federigo Gonzaga in 1531 and executed by Giulio Romano in about $153^{2-1534.50}$

- An Italian summary of Appianus' description of the triumph of Scipio [fol. 97], probably drafted in connection with Giulio's designs of the cartoons of a cycle of tapestries of that subject, a commission from Francis I of France, work on which probably began in about 1533. It closely corresponds to Giulio's modelli for the series now in the Louvre. ${ }^{51}$

49 Above, Chapter 1; on Castiglione's tomb, see Cian 1942; Laskin 1967;Howard Burns and Pier Nicola Pagliara, 'La Capella Castiglioni', in Giulio Romano 1989, pp. 532-534.

50 Bacou/Béguin 1983, cat. nr. P3, pp. 123-126; Hartt 1958, I, pp. 208-211; Juřen, 1986, p. 136; Giuseppe Pecorari, 'Le commissioni artistiche della famiglia Boschetti', in Giulio Romano 1989, pp. 442-445.

51 Hartt 1958, I, p. 227-231; Jestaz/ Bacou 1974; Juřen 1986, pp. 112-117 and 176-177; Nello Forti Grazzini, 'Arazzi', in Giulio Romano 1989, pp. 466-479. 
- The inscription, likewise disappeared or never realized, which was intended to comment the stucco double frieze in the Camera degli Stucchi, a text of capital importance for the dating and the disputed interpretation of this most archaeological of Giulio's creations [fol. $42 \mathrm{v}] .^{52}$

\subsubsection{Copies as Source for Strada's Collection of Drawings: Vienna, Cod. $\min .21,1$ and 21,2}

The two volumes in Prague both contain much original material, and can be considered as the principal more or less intact relics of Strada's graphic collection. The Strahov codex also included copies of some of these and of other drawings, copies that were produced in Strada's own workshop. The Österreichische Nationalbibliothek in Vienna owns another miscellaneous item that consists almost entirely of similar workshop copies. This item, Codex miniatus 21, consists of three huge separate folio volumes, the first two of which are finished albums in themselves, each provided with a title page stating their subject and their provenance from Strada's Musaeum..$^{53}$ These two are both libri di disegni, similar in make up to Strada's numismatic albums.

The first album, Codex miniatus 21,1, is dedicated to helmets and other headdresses in the 'antique' style, but actually copied from designs by contemporary mannerist artists and intended to be used in costume designs for contemporary festivals. Though its title, Ancient helmets and crests such as once were used by the Greeks and the Romans, and also by other peoples, both in spectacles and public games, and in war <... >, suggests that it presents reliable images of real antique Roman helmets and other headgear, in fact it contained almost exclusively decorative headdresses intended as costume accessories for courtly festivals such as tournaments, masques and theatre performances. Careful comparison of these designs with those preserved elsewhere might throw some light on Strada's sources. Here I will merely show one helmet, perhaps part of a costume for an actor impersonating a Greek hero, based on an invention known from an as yet anonymous drawing in a private collection. ${ }^{54}$ [Figs. 13.41-13.42]

$5^{2} \quad$ Hartt 1958, I, p. 58; Verheyen 1977, p. 124; Juřen 1986, p. 148.

53 ONB-Hs, Codex miniatus 21, 1-3. The last drawing (fol. 460/190) bears an annotation 'Seindt in disen Buch gerissen Pletter und Khunstuckh [sic] Pey Hand 230 Stuckh. 1629. Jars / JS [?? or abbreviation for: Christoph?]. Ranfft d. Elter von Wiessendal', which suggests that it had remained in the possession of Ottavio Strada's illegitimate daughter Anna Maria, Rudolf II's mistress, who had married Rudolf's chamberlain Christoph Ranfft, ennobled as Freiherr von Wiesenthal, and died in 1629. Still in the 1640 os contacts between Ranfft and his brother-in-law Ottavio II, already long resident in France, are documented.

54 ÖNB-HS, Codex miniatus 21,1: Galearum antiquarum cristatarum quibus olim Graeci et Romani, atque alii etiam populi, tam in spectaculis et ludis publicis, quam in bellis usi sunt, 

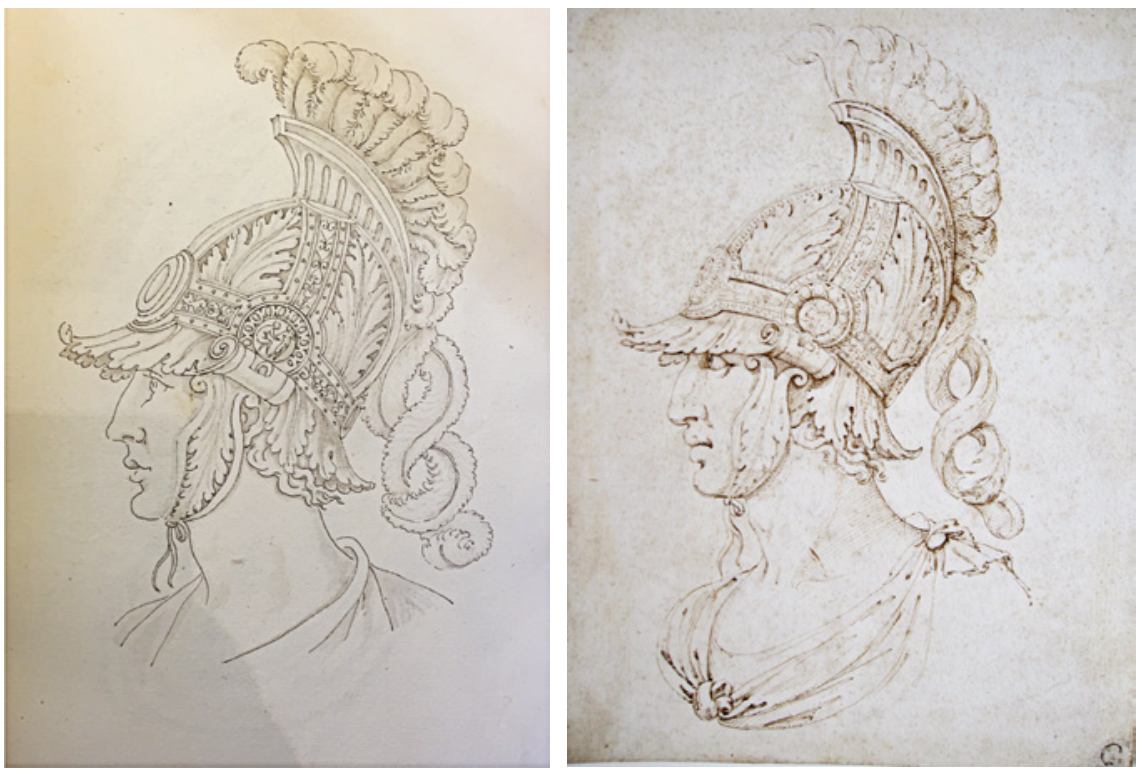

FIGURES 13.41-13.42 Workshop of Jacopo Strada: helmet in the Greek manner, from his Galearum antiquarum (Vienna, Österreichische Nationalbibliothek, Cod. min. 21,1, fol. 35/33r) compared to an anonymous design for a helmet in the Greek manner, drawing in pen and ink, private collection.

The second album, Codex miniatus 21,2, is a more serious antiquarian work, providing circa hundred and fifty drawings of Roman full-length statues. Just like Strada's numismatic albums these volumes were intended for his patrons, and the drawings in them are all uniformly drawn copies produced in Strada's workshop. These copies were based on the examples- the drawings and perhaps to some extent the prints-in his own collection. They thus provide some indication of the type, the quality and the quantity of the material Strada had collected. Only occasionally the material examples can be identified with some certainty: a good example is a sheet in the Cabinet des Dessins of the Louvre depicting three classical female statues [Fig. 13.47], which shows these antiques - they are identified with objects present in Rome in the sixteenth century - all from exactly the same angle as the relative drawings in Strada's Statuarum antiquarum [Figs. 13.43-13.45]. This makes it very likely that it has been Strada's model.

formae atque imagines ex aeneis atque marmoreis statuis, tum etiam ex aeneis, argenteis, aureisque numismatibus desumptae et elegantissimae aptissimeque delineatae, fol. $35 \mathrm{r}$. Strada's model is in a private collection; I am grateful to Monroe Warshaw for having drawn my attention to this drawing and having provided me with a photograph. 


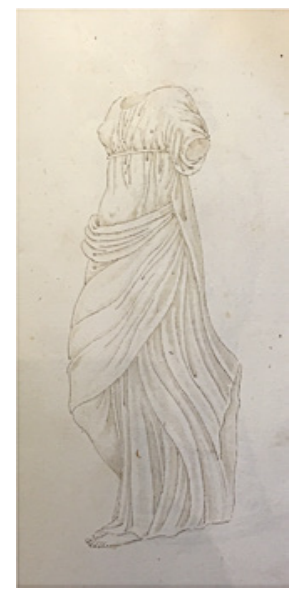

FIGURES $13.43-13.46$
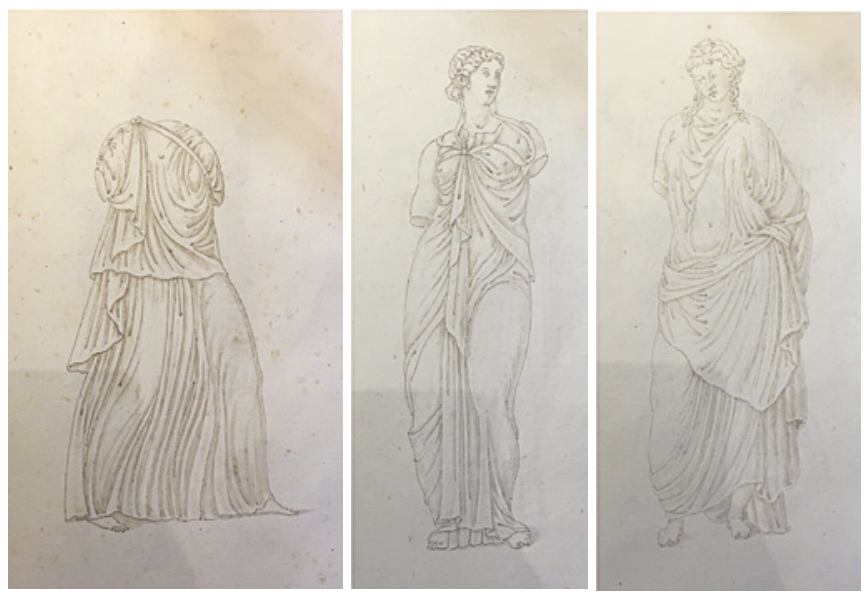

Drawings from Strada's Antiquarum Statuarum, Codex miniatus 21,2, fols. 204/97r., 207/10or., 250/142r. and 192/86r; Vienna, Österreichische Nationalbibliothek.

The Louvre owns a few more, closely related drawings in the same hand-at present all improbably attributed to Francesco Primaticcio-which are also copied in the Vienna codex. ${ }^{55}$ The verso of one of these sheets [Fig. 13.48;

55 Strada's studio copy preserved in his Antiquarum statuarum tam deorum quam dearum, heroum et eorum coniugum, tum etiam imperatorum et eorundem uxorum formae, et effigies ex antiquis marmoreis et aeneis statuis quae et Romae et aliis in locis inveniuntur ad vivum depictae atque quam fidelissime repraesentatae, öNB-Hs, Codex miniatus 21,2; the relative drawings in Paris, Louvre, Cabinet des Dessins, inv. nr. 22.633 [Strada fol. 22], 22.634 [Strada fol. 86], 22.646 [not copied in Strada's album], 22.647 [not in the album], 22.649 [Strada fol. 17], $22.65^{\circ}$ [not in the album], 22.651 [not in the album], $22.65^{2}$ [Strada fols. 97, 100, 142]; cf. Jansen 1991, pp. 59-76. Frits Lugt included them in his catalogue of the Netherlandish drawings in the Louvre, and saw a connection with the so-called Anonymous A, one of the draughtsmen of the Berlin Heemskerck sketchbooks (Lugt 1968, cat. nrs. 240-247) who has been tentatively identified with Hermannus Posthumus (Dacos 1989). Strada and Posthumus probably crossed paths during their partly parallel careers, in Mantua, in Rome and/or in Germany, and that Strada may have acquired or even commissioned antiquarian drawings from him and from other Netherlandish masters working in Italy is perfectly plausible. In his Index sive catalogus [nr. 16] he refers to a large oil painting, a bird's eye view of ancient Rome showing the different types of sports and entertainments, which he had commissioned from 'quodam exellenti pictore belga': a painting which was similar to, though not identical with Posthumus' romantic view of Rome in the Liechtenstein collection (Rubinstein 1985; Dacos 1985). In his catalogue of the exhibition Primatice: Maître de Fontainebleau of 2004, however, Dominique Cordellier has reattributed these Louvre drawings to Francesco Primaticcio (PRIMATICE: Maitre De Fontainebleau 2004, pp. 138-139 e 146-148, cat. nrs. 35-37), an attribution which is far from convincing also with respect to style and quality of the drawings. The valuable essay by Bernadette Py, 'Histoire des dessins de Primatice du XVIe au XVIIIe siècle' (ivi, pp. 54-59) 

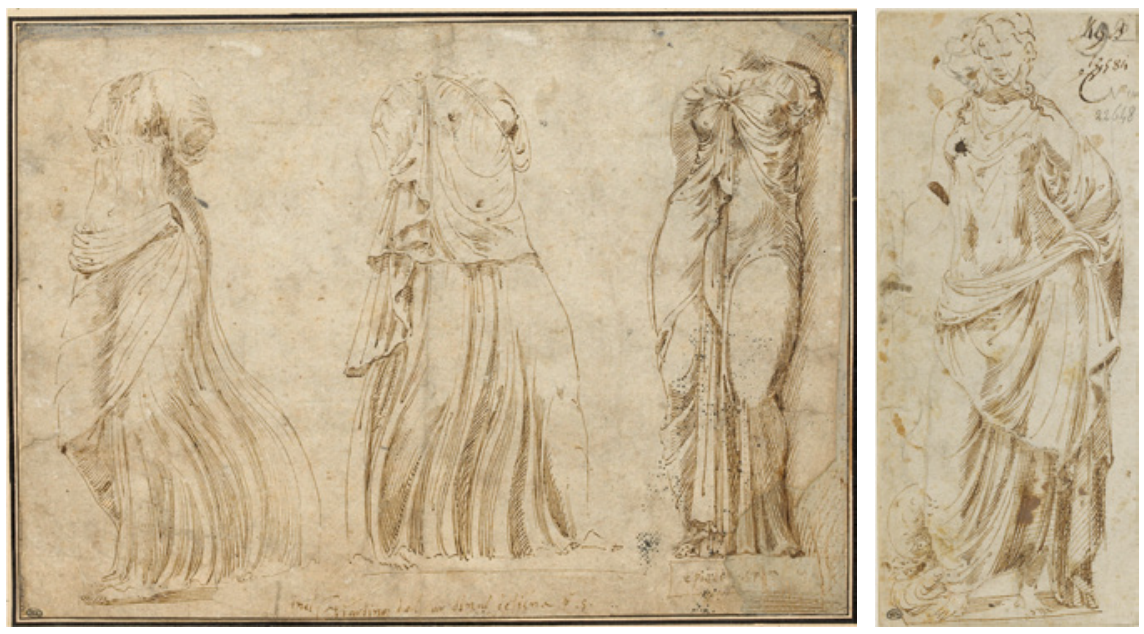

FIGURES 13.47-13.48 Attributed to Francesco Primaticcio (?), drawings of antique statues in Rome that served as models for Strada's Antiquarum Statuarum; Paris, Louvre.

cf. Fig. 13.46] is actually blackened in charcoal in order to trace the outline of the invention on a clean sheet, a copying technique with which Strada had familiarized himself in Giulio's studio, and which was the standard technique used in the production of the numismatic volumes and other libri di disegni from his workshop. ${ }^{56}$

\subsubsection{Copies as Source for Reconstructing Strada's Collection of Drawings: Vienna, Codex miniatus 21,3}

The third volume of Codex miniatus 21 is of particular importance, since it contains miscellaneous material which provides some indication of the range of Strada's interest. Its principal component is a further hundred and fifty copies of designs for goldsmith work by Giulio Romano, Polidoro da Caravaggio, Francesco Salviati and others, very similar to those in the libri di disegni at Cambridge and Berlin studied by John Hayward and to the similar copies included in the Strahov codex. Some of them reproduce inventions the originals of which are included in the Strahov codex, but it must be assumed that in addition to these Strada also owned the originals, workshop copies or, in the

unfortunately provides no elements that could help solve the earliest provenance of these sheets.

$5^{6}$ The practice is described in Armenini 1587, I, pp. 76-77 and many drawings from Strada's workshop bear witness of it. 

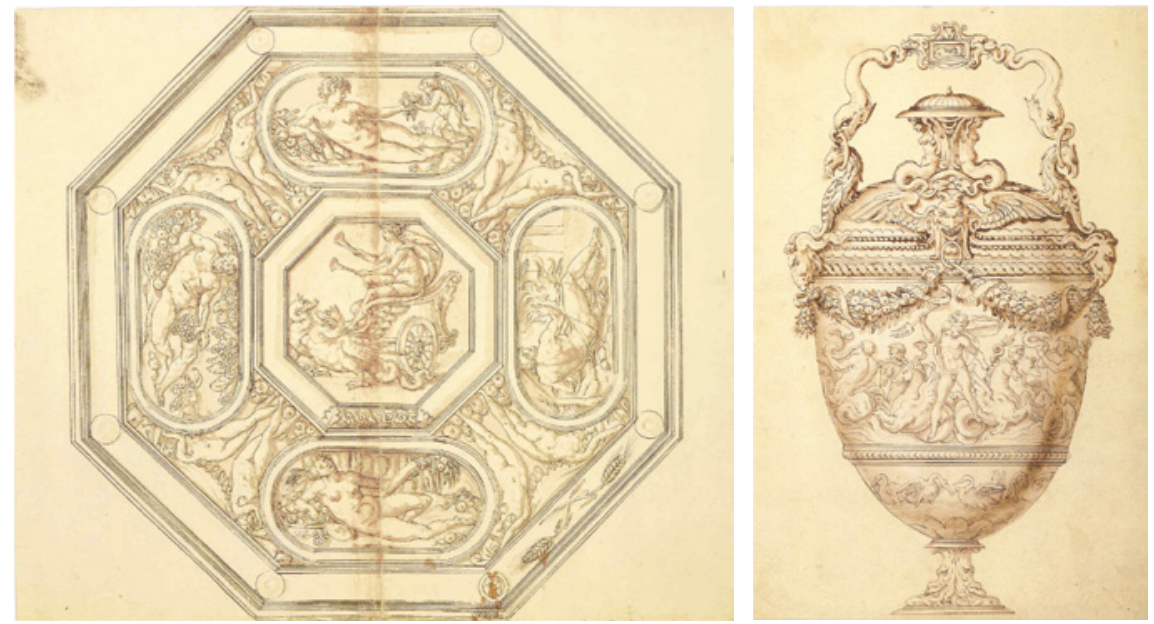

FIGURES 13.49-13.50 Circle or ?workshop of Jacopo Strada, design for an octagonal platter or perhaps a ceiling; drawings in pen and wash from the Sorokko Album.

case of Polidoro, sets of prints of the other inventions which he included in his libri di disegni.

These drawings are related to the Sorokko album, a collection of thirty-seven drawings of inventions for tableware that are very similar, and in a number of cases identical to those in the various Strada albums. For that reason they have been attributed to Jacopo Strada, but they are certainly not in his own hand, nor in that of his son Ottavio [Figs. 13.49-13.50.]. ${ }^{57}$ In fact they are of a far higher degree of finish and sophistication than most of the drawings/copies in Jacopo's and Ottavio's albums. The use of identical sources nevertheless suggests a connection: it is perfectly possible that they were commissioned by Strada for himself or for one of his patrons from an as yet unidentified, Italian draughtsman, for instance when he was in Venice in the late 1550 s or in the late 1560 . $^{58}$

57 On the Sorokko Album, see Lawrence 2007; a selection of the drawings were offered for sale at Sotheby's in 2010, as Jacopo Strada and workshop (Old Master Drawings 2010, pp. $5^{0-74}$, cat. nrs. 40-61. I am grateful to Cristiana Romalli of Sotheby's for providing me with photographs and discussing these drawings with me. I have discussed them more in detail elsewhere (Jansen 2014, pp. 164-168).

58 BSB-HS, Cod. Icon. 199, attributed to Strada in a Munich library inventory of 1582 . This scenario justified Sotheby's attribution of the Sorokko drawings to 'Jacopo Strada and workshop'. 
This was standard practice: a volume of similar goldsmith's drawings Strada provided to the Kunstkammer of Duke Albrecht V of Bavaria contains (copies of?) similar designs by or after a German artist, traditionally identified with Erasmus Hornick. On the basis of these a large group of drawings in various albums all over Europe and the United States have traditionally been attributed to this master, an Antwerp goldsmith who had settled in Augsburg in 1555, moved to Nuremberg in 1559, then back to Augsburg in about 1566, and in 1582 ended up at the Imperial Court in Prague, where Rudolf II appointed him 'Kammergoldschmied', a function he held only a few months before he died early in October $1583 .{ }^{59}$ This group of drawings has been studied exhaustively in an ample monograph by Silke Reiter, who concludes that in fact even a tentative attribution of most of the drawings to Hornick's hand is warranted only in a few cases, whereas the close connection with material from the Strada workshop strongly suggests that in fact most of it was acquired at some time, or even commissioned by the Stradas - including those that can be attributed to Hornick himself. As Reiter suggests, it is perfectly possible that Strada, recognizing Hornick's talent and creativity, had commissioned him to supply him with such inventions, in order to include them in the libri di disegni he provided his patrons. ${ }^{60}$ And he may have used them as models to show to patrons wishing to order sumptuous tableware-he may have acted as an 'agent' for Hornick, in a similar way as is documented earlier in his connection with Wenzel Jamnitzer. ${ }^{61}$

The copies in such libri di disegni were commissioned and paid for by Strada. But he probably allowed the various draughtsmen he employed — for instance in his projects in Rome in the mid-1550s, such as Giovanni Battista Armeninito copy his originals for their own use. In either case one may suppose that Strada owned either the original designs or at least careful copies of the original inventions. This holds also for the first twenty six sheets of Codex miniatus 21,3, which reproduce several figurative designs by Giulio Romano, chiefly for elements of the decoration of the Palazzo del Te. Many of these designs can be

59 The attribution to Hornick first advanced in Hawyard 1968; for Hornick's biography. see in Reiter 2012, Ch. 3, pp. 31-6o.

6o Reiter is doubtless right in doubting that a young but successful goldsmith and engraver as Hornick would just have gone to work in the 'copy shop' of the Strada's to reproduce inventions of others (ibidem, p. 242).

61 In her paragraph, 'Jacopo and Ottavio da Strada - die Agenten Erasmus Hornick's?' (ibidem, pp. 241-242), Reiter does not actually suggest this, but the hypothesis is warranted that the expertise Strada offered his patrons at court included mediation with his old and newer Nuremberg associates, in particular Jamnitzer, for whom he may have acted as a local agent. On Strada's connection with Jamnitzer, cf. above, Ch. 2.5. 

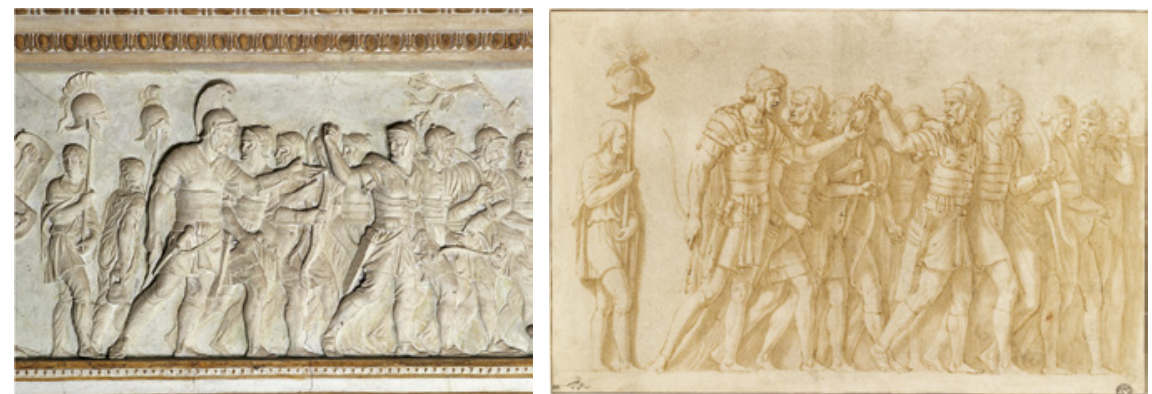

FIgURE 13.51 Francesco Primaticcio, after Giulio Romano, Detail of the battle order of Caesar, double frieze in the Camera degli Stucchi, Palazzo del Te, Mantua.

FIGURE 13.52 Giulio Romano, design for a section of the double frieze in the Camera degli Stucchi, Paris, Louvre.

related to the reliefs in the coffers of the barrel-vault in the Camera degli Stucchi of the Palazzo del Te [fols. 1-26; Figs. 13.53-13.58]. Since a number of these drawings differ in detail from the stuccoes as executed, Strada's copies were certainly derived from Giulio's original modelli, or based on workshop copies of these that were in Strada's possession. ${ }^{62}$ The former option is more likely: from the Index sive catalogus we know that Strada also owned-and intended to publish - the complete set of Giulio's designs for the double frieze, representing Caesar's battle-order, in this same room:

A picture of the order in which Caesar the dictator was wont to set out with his legions, infantry and cavalry as well as his auxiliary troops; drawn after the pictures made by Giulio Romano in the Palazzo del Te outside Mantua: a most perfect and wonderful thing, and worth seeing; the originals of which I bought from Raphael, Giulio's son.

This entry helps solve the problem of the iconography of the frieze in the Camera degli Stucchi, and it is of some significance that an inscription explaining

62 The following drawings represent inventions used in the ceiling of the Camera degli Stucchi: fols. $1,2,3,6,7,9,10,16,17,21,23,24$ and 26 . In view of the fact that many of these inventions were copied already in Giulio's own workshop, and various versions have been preserved of many of them, an attempt to identify the individual sheets actually in Strada's possession - if at all feasible-would involve detailed material and provenance research that far transcends the limits of this study; the items illustrated here serve merely as examples. 

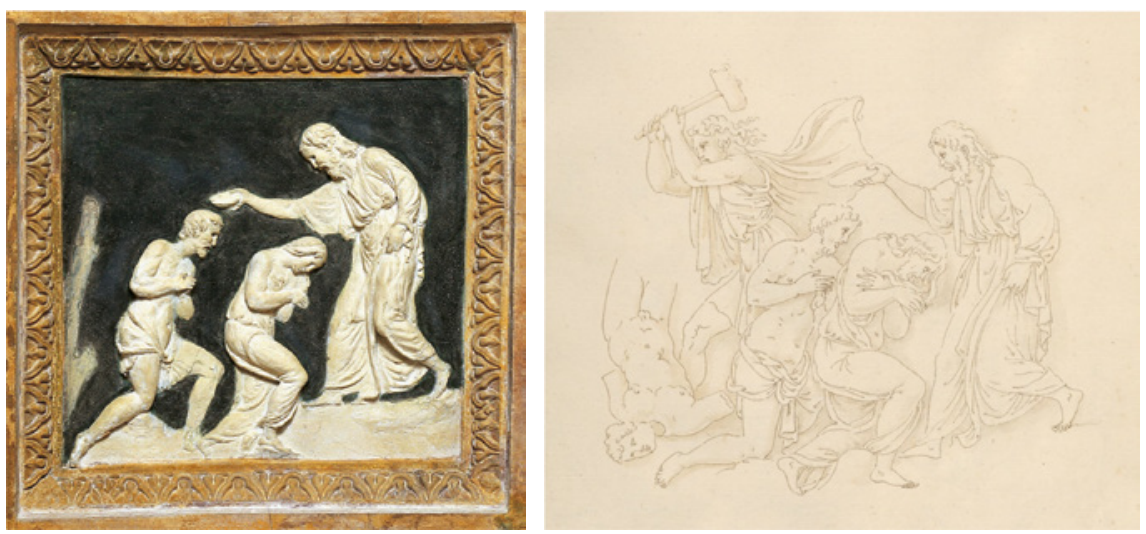

FIGURE 13.53 Francesco Primaticcio, after Giulio Romano, The baptism of the Early Christians, central panel of the coffered ceiling of the Camera degli Stucchi, Palazzo del Te, Mantua.

FIGURE 13.54 Codex minatus 21,3, fol. 6v.: workshop of Jacopo Strada, copy of Giulio's design for The baptism of the Early Christians.

this frieze is recorded in the Codex Chlumczansky. ${ }^{63} \mathrm{~A}$ conspicuous number of Giulio's designs for the frieze have remained together in the Cabinet des Dessins of the Louvre [Figs. 13.51 and 13.52], and it is likely that Strada would likewise have kept them in a separate album or file together with the modelli for the ceiling panels. The complete set of copies preserved in the Albertina may well be the set Strada prepared or commissioned for the engraver. ${ }^{64}$

Perhaps the most interesting of Strada's copies of the decorations of the Camera degli Stucchi is his rendering of the baptism of converts, the only Christian theme represented in this very pagan room [fol. 6; Fig. 13.54]. Strada's

63 Strada explicitly states that he had acquired Giulio's original drawings of the frieze from Raffaele Pippi: Index sive catalogus (Appendix D), nr. 14. Many of these have been preserved in the Cabinet des Dessins of the Louvre. The lost inscription-or perhaps its concept that was never executed-is transcribed on fol. $42 \mathrm{v}$ of the Codex Chlumczansky, again linking this volume with Strada's collection. The codex Chlumczansky also includes a resume of Appianus' description of the Triumph of Scipio, subject of a tapestry cycle commissioned by the Gonzaga that is among Giulio Romano's most monumental compositions. It is tempting to think that Strada also owned some of Giulio's original design for these, but if so, he does not appear to have thought of publishing these-probably because they would already have been too familiar.

64 Albertina, inv. nrs. 15442 and 15445 (strip of 22 sections pasted together; cf. Birke/Kertész 1992-1997, IV). I have not seen the originals; a further investigation will show whether these drawings reproduce the frieze as executed-in that case they probably were commissioned by Strada during his stay in Mantua in 1567 , perhaps from Ippolito Andreasior from the autograph designs, as his entry in the Index sive catalogus suggests. 

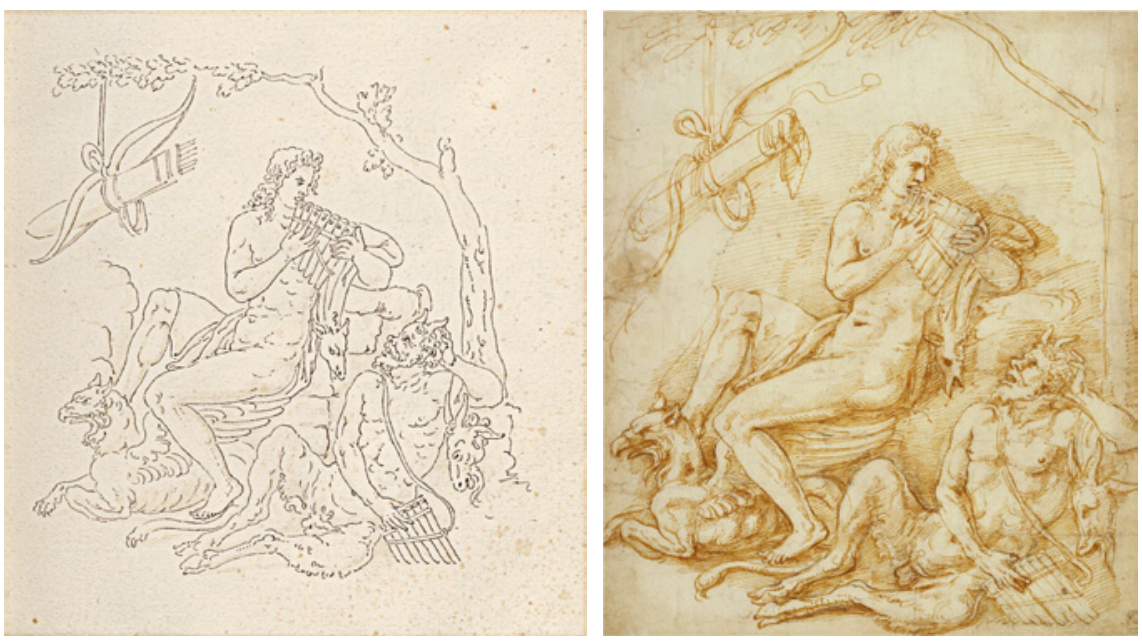

FIGURE 13.55 Workshop of Jacopo Strada, Apollo and Pan, copy of a design by Giulio Romano for a compartment of the ceiling of the Camera degli Stucchi, Palazzo del Te; Österreichische Nationalbibliothek, Cod. min 21,3, fol. 8r.

FIGURE 13.56 Giulio Romano or workshop, Apollo and Pan, design for a compartment of the ceiling of the Camera degli Stucchi, Palazzo del Te; Royal Collections Trust.

copy of Giulio's lost design includes an iconoclastic motif which Primaticcio, or whoever executed the panel [Fig. 13.53], declined to include, presumably afraid of overburdening the composition. Other themes from this ceiling include Mercury teaches Bacchus to read, Apollo and Pan [Figs. 13.55-13.56], and Caritas Romana [Figs. 13.57-13.58].

Apart from drawings related to the ceiling-panels of the Camera degli Stucchi, we find similar copies after the designs for the Camera dei Venti and the Camera delle Aquile. Of particular interest is a design [Fig. 13.59] for a stucco relief incorporating the antique crouching Venus 'Lely', at the time in the Gonzaga collection, that was inserted in the west end-wall of the Galleria dei Marmi in the Palazzo Ducale, as is documented in Andreasi's drawing [fol. 22; Fig. 13.60-13.61].65

One of the copies is derived from a lost drawing by Giulio otherwise only known through a print by Adamo Scultori. ${ }^{66}$ Some scenes that I have not been able to identify possibly document projects that were never realized, or have

65 Fols. 307/24, Departure of a ship; 308/ 25, Diana with two hounds; cf. Belluzzi 1998, Saggi, p. 396, cat. nr. 524; fol. 295/12, Amorino on Jove's Throne, cf. Belluzzi 1998, pp. 414, cat. nr. 662.

66 Fol. 287/4, Cupid Playing with the Arms of Mars, not executed element of the design for the stucco relief of Mars resting in one of the Lunettes in the Camera degli Stucchi. 

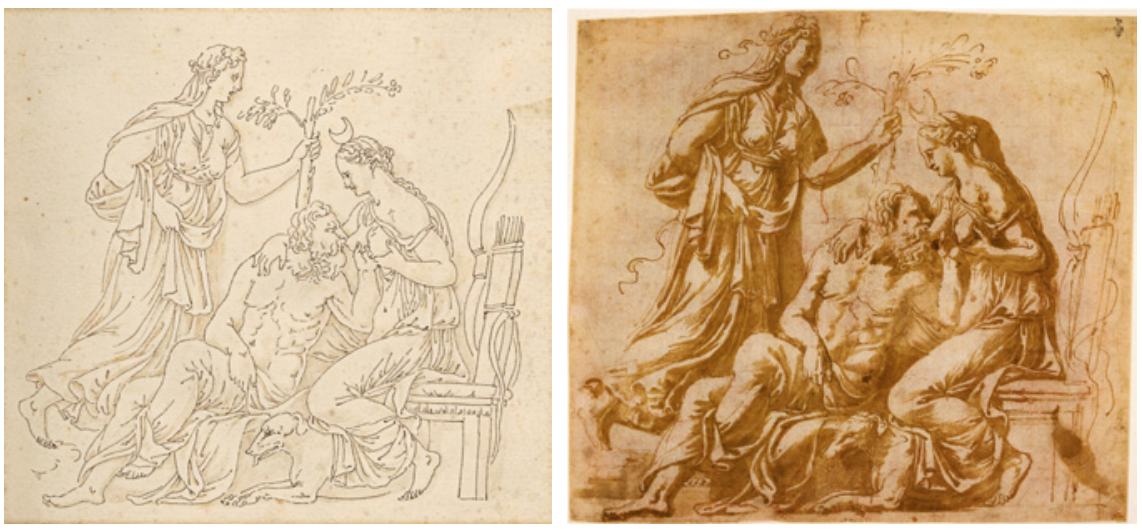

FIGURE 13.57 Codex miniatus 21,3, fol. 285/2r.: workshop of Jacopo Strada, Caritas Romana, copy of a design by Giulio Romano for a compartment of the ceiling of the Camera degli Stucchi, Palazzo del Te.

FIGURE 13.58 Giulio Romano or workshop, design for a compartment of the ceiling of the Camera degli Stucchi, Palazzo del Te (Chantilly, Musée Condé).

been lost since (such as the decoration of the Palazzina della Paleologa or of the Gonzaga villa at Marmirolo).

Almost all of these copies in Codex miniatus 21,3 reproduce inventions by Giulio Romano, but for lack of material it is unclear whether this is due to any particular penchant for the work of his former master on Strada's part, or whether it is merely the result of the arbitrary selection of time and chance. The Codex miniatus 21,3 also includes a number of rather unattractive reproductions of Perino del Vaga's sopraporte in the Sala Paolina of the Castel Sant'Angelo [fols. 71-76; Fig. 13.62 and 13.63]; but it is difficult to decide whether these reproduce Perino autographs, or are simply sketches after the executed frescoes.

Strada was particularly proud of having acquired le più belle cose que havesse Raffael d'Urbino' with his purchase of Giulio's estate. In view of the almost divine status of Raphael at the time-and ever since-it would be of particular interest to know exactly what drawings these may have included. Unfortunately we know no more than that they included some of Raphael's autograph designs for the Vatican Stanze:

Moreover I have with me in drawing all those works, that in the Pope's rooms or chambers have been painted and made by the aforesaid Raphael of Urbino, and also some of their originals are in my possession. ${ }^{67}$

67 Index sive catalogus (Appendix D), nr. 43. The drawings of Raphael's Loggia are those commissioned by Strada from Giovan Battista Armenini c.s. ca 1554-1555, and still preserved in the Austrian National Library (cf. below). 

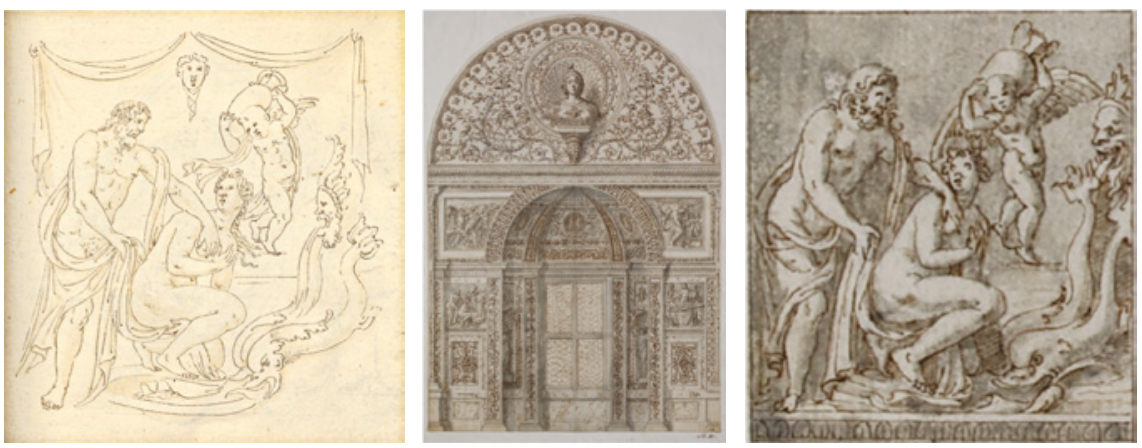

FIGURE 13.59

Codex Miniatus 21,3, fol. 305/22: Workshop of Jacopo Strada, Copy after a drawing by Giulio Romano or his circle for a stucco relief incorporating an antique marble Venus in the Galleria dei Marmi in the Palazzo Ducale.

FIGURES 13.60-13.61 Ippolito Andreasi, documentary drawing of the west wall of the Galleria dei Marmi, Palazzo Ducale, Mantua, and detail showing the same relief still in situ.
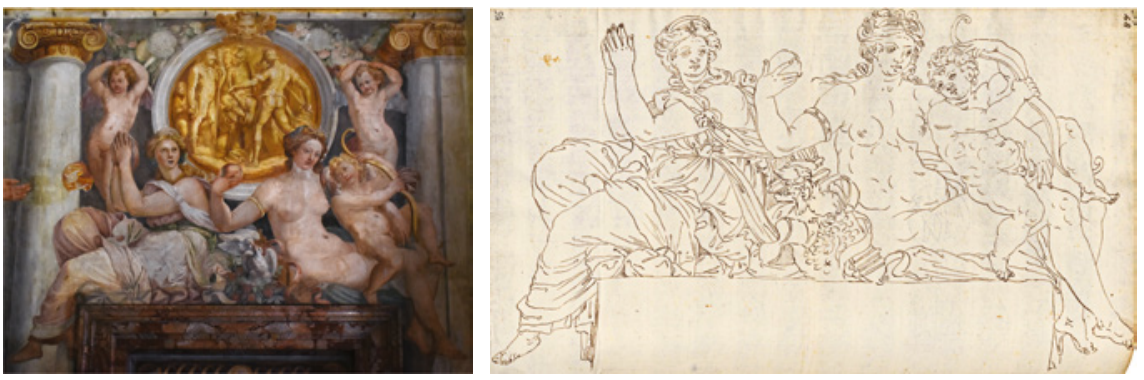

FIGURE 13.62 Perino del Vaga, sopraporte in the Sala Paolina, Castel Sant'Angelo, Rome, ca. 1533 .

FIGURE 13.63 Codex Miniatus 21,3, fol. 376/75: copy of a design for, or a drawing after Perino del Vaga's sopraporte in the Sala Paolina.

The context implies that Strada owned both a set of documentary drawings of the Stanze similar to those of the Vatican Loggia he had himself commissioned from Giovan Battista Armenini, and some of Raphael's autograph designs for these-it is tempting to think that at least some of them may have been worked out modelli of the entire compositions. These have not been preserved and the few autograph studies for the Stanze that have survived have since been dispersed all over Europe, unfortunately without any indications which of them may once have been in Strada's collection-perhaps those from the Albertina illustrated here as randomly chosen examples? [Figs. 13.64-13.65]. The only concrete object from Raphael's Nachlass that can reasonably be assumed to have passed through Strada's hands is the manuscript of Fabio Calvo's translation of 

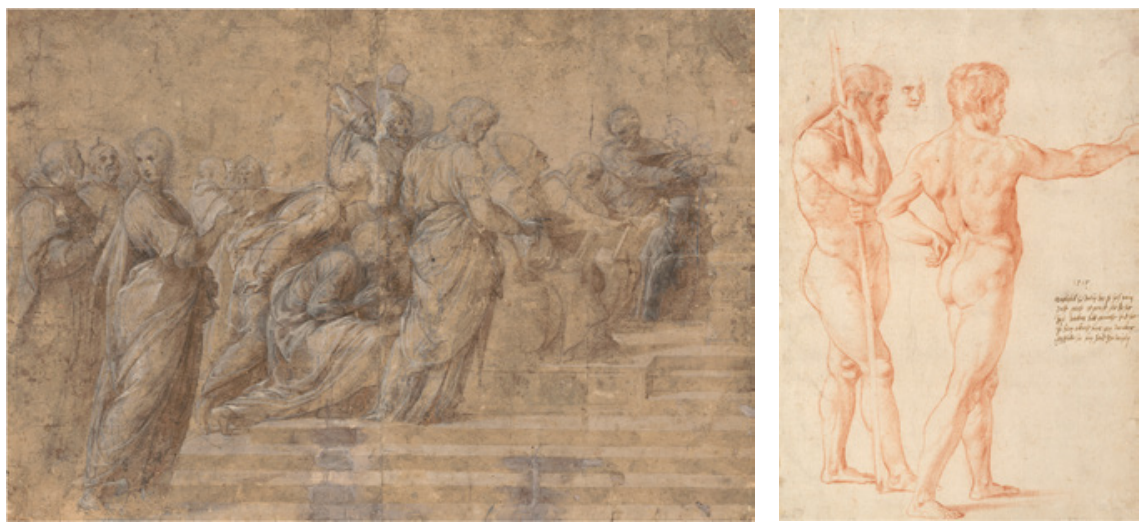

FIGURES 13.64-13.65 Raphael, compositional study for the Disputà, Stanza della Signatura, 1509, and a figure study for The Battle of Ostia, Stanza dell'Incendio, 1515. At least some of such studies were in Strada's possession, though these cannot be identified.

Vitruvius, the presence of which in Munich can be best explained in terms of the Strada-Fugger connection. ${ }^{68}$

\subsubsection{The Christ Church Lion}

It was standard practice for apprentices and assistants in an artist's workshop to copy designs: thus they could build up a personal stock of inventions to draw upon for future inspiration. Strada's collecting habits may well have originated in a similar manner in Giulio's studio. But that makes it difficult to identify the exact exemplar of a given invention that Strada may have owned. So here again the objects mentioned and illustrated are merely intended to provide an impression of size, character and quality of his Musaeum. In the case of individual drawings the lack of collector's marks and of autograph annotations makes it almost impossible to establish their provenance from Strada's Musaeum with any certainty.

At present there are only two drawings, now in Christ Church Picture Gallery, Oxford, which can securely be demonstrated to have been among Strada's possessions. These are actually two halves of the same sheet bearing related inventions for a mural decoration, which were separated at a later date. One of them is still provided with an explanation in Strada's hand, jotted onto a narrow strip of paper attached to its bottom [Figs. 13.67-13.68]: 

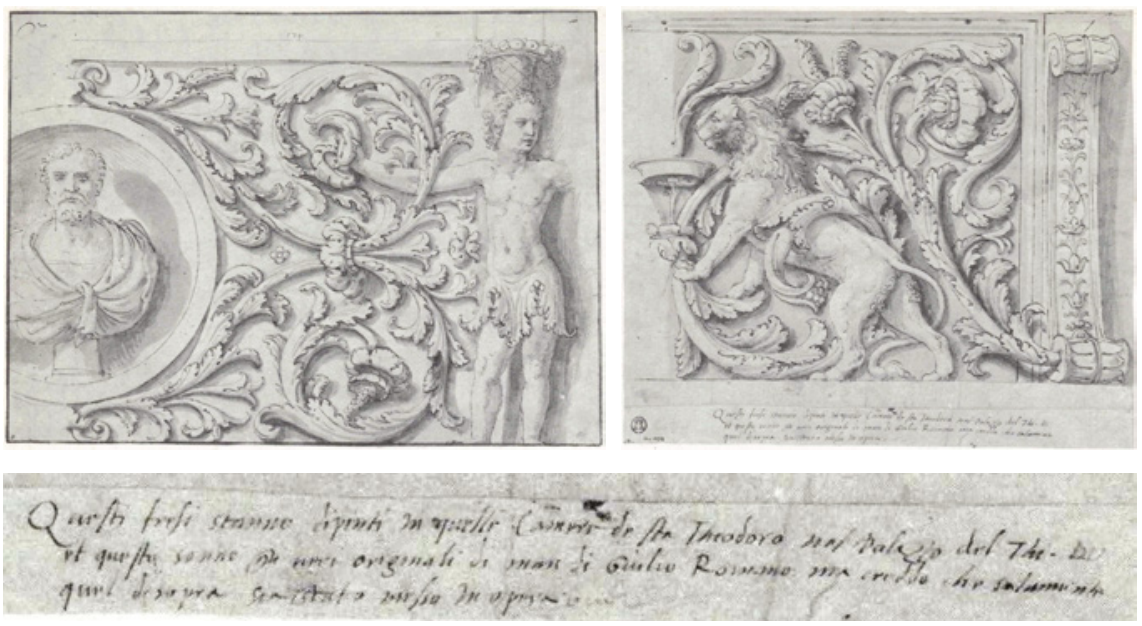

FIGURES 13.66-13.68 Giulio Romano or workshop, designs for a mural decoration in the

Palazzo del Te, and detail of Strada's inscription. Oxford, Christ Church Picture Gallery.

These friezes are painted in the chambers where Theodoro lives in the Palazzo del Te; and these are the true originals in the hand of Giulio Romano, but I think only the one above has been executed.

Both sheets are rather beautiful ornamental drawings from Giulio Romano's immediate circle, if not—as Strada insists—by his hand [Figs. 13.66-13.68]. They are sketches for the painted friezes to be executed by one of Giulio's assistants in some of the rooms of the Palazzo del Te. ${ }^{69}$ They entered the collection of Christ Church with the legacy left to the college by General John Guise $(1682-1765)$. It is unlikely that these were the only items from Strada's $M u$ saeum that had ended up, perhaps by way of Lord Arundel's collection, in the hands of this connoisseur soldier. We can fairly assume that those of Giulio Romano's designs for vases and candelabra all' antica in Oxford which were

69 Oxford, Christ Church, inv. nrs. 938 and 939. They are designs for painted or perhaps stucco decorations in the Appartamento delle Metamorfosi in the Palazzo del Te (ca 1527-1530). The drawings were not considered autograph by Oberhuber and Ferino Pagden (verbal communication); cf. Byam-Shaw, 1976, I, pp. 134-135, cat. nrs. 451-452; II, pls. 233-234; Jansen, 1988, pp. 138-139; cat. Giulio Romano, 1989, pp. 378-379. The inscription reads: 'Questi fresi stanno dipinti in quelle camere d[ove?]e sta Teodoro nel Palazzo del Thi; et questi sonno gli veri originali di man di Giulio Romano, ma creddo che solamente quel di sopra sia stata messa in opera'; 'Theodoro' probably indicates Teodoro Ghisi, the caretaker of the palace. 

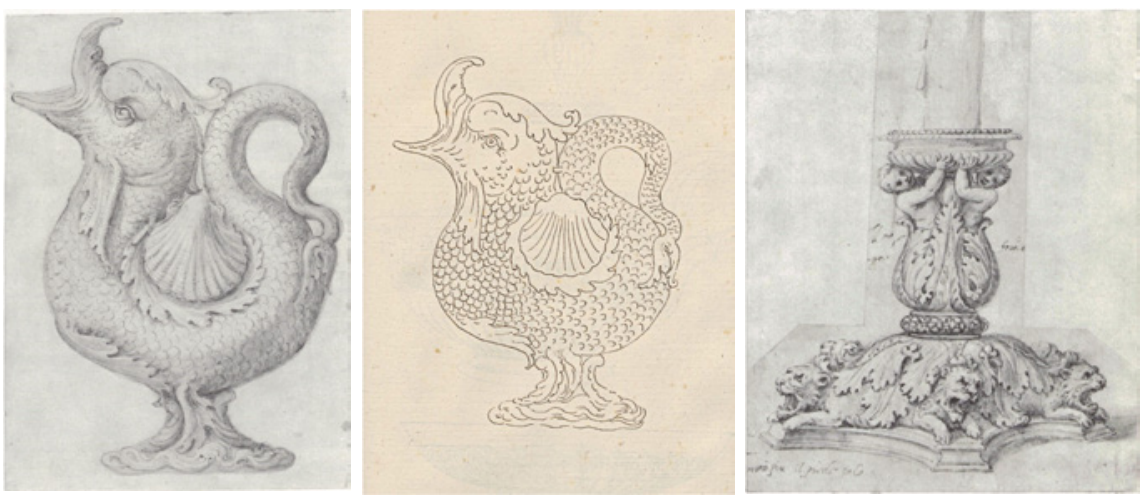

FIGURES 13.69-13.70

Giulio Romano or workshop, designs for a ewer in the form of dolphin (Oxford, Christ Church) and the copy from Strada's workshop, Vienna; önb-hs, Cod. min. 21,3, f. 438/148r).

FIGURE 13.71

Giulio Romano, design for a candlestick, Oxford, Christ Church.

copied in Strada's libri di disegni-an example is the ewer in the form of a dolphin [Figs. 13.69 and 13.70] — were acquired by General Guise from the same source. This is a virtual certainty for a design for a candlestick of which the (truncated) inscription seems to be in Strada's hand as well [Fig. $\left.{ }^{71}\right] .{ }^{70}$ In the same way Giulio's autograph designs for similar inventions found elsewhere and of which copies are included in Strada's albums must once have made part of Strada's holdings. ${ }^{71}$

Apart from the Strahov codex the Oxford drawing provides the only material evidence of the way Strada organized his material. It suggests that he kept the drawings he most valued in albums which were probably thematically arranged - thus he probably kept all the original designs for the Palazzo del Te together in a separate volume - and shows that at least occasionally he identified the invention and recorded its original purpose. Whether all his drawings were so carefully stored and annotated must remain an open question: after all this one instance may have been exceptional, since it concerns a drawing by the master whose work and example had profoundly influenced his artistic education and which related to a building he had known and admired even as a youngster.

70 The Dolphin ewer: Byam Shaw 1976, I, p. 131, cat. nr. 429, pl. 236; a very primitive copy from Strada's workhop in ÖN-HS-21,3, fol. 432/148; the candlestick Byam-Shaw, 1976, I, p. 131, cat. nr. 424; II, pl. 232; a related version in the Strahov Codex, cf. Bukovinská/Fučíková/ Konečný, 1984, pp. 81 and84, cat. 7/10.

71 Even then it is difficult to be certain, since many of these inventions had already been copied in Giulio's own workshop, and many versions of them may have circulated at the time; in future Valerie Taylor's research will throw light on this issue. 


\subsection{Strada's Commissions of Visual Documentation: Antiquity}

\subsubsection{Acquisitions in Rome: Drawings of Coins and Sculpture}

Apart from the autograph drawings by celebrated Italian masters of his time and from their workshops which Strada had been able to acquire by favour of certain chance opportunities, the graphic section of Strada's Musaeum also included series of drawings and illustrated manuscripts that he had commissioned himself. These drawings were not considered as works of art as such, but functioned to document both the principal monuments of Antiquity and the most outstanding achievements of the art of his own time. Such documentation was the fruit of a deliberate programme of acquisition, a programme which itself probably resulted from Strada's conversations with his patron, Hans Jakob Fugger. Fugger had commissioned Strada to set up and organize a Corpus of drawings of ancient Roman coinage, a project which continued into the 156 os and resulted in literally thousands of numismatic drawings. During Strada's travels to Lyon and Rome he remained constantly engaged in the perfection of this Magnum ac novum opus, both providing drawings himself, and having them drawn under his own supervision by the various draughtsmen he employed to this end. As we have seen earlier, one of these draughtsmen was the young Giovan Battista Armenini. In his account of Strada's purchase of Perino's drawings, Armenini explains that he could study these at leisure, because at the time he was living in Strada's house, employed in drawing:

...certain antique medals of bronze, and of gold, in watercolours, in the size of a palmo; which copies with their reverses, he then sent to the Fuggers, wealthy merchants of Antwerp, a powerful city of Flanders, first having collected them into most beautiful books... ${ }^{72}$

Armenini was only one among many of the young artists that had flocked to Rome in those years who were employed by Strada in these labours, and the execution of the numismatic drawings was only one of the tasks he set them. Armenini relates how Strada had them produce a set of drawings documenting the decoration of the Vatican Loggia — to be discussed below—a set of which he himself took 'to Spain to the great court of King Philip', together with:

...countless other drawings, which he bought everywhere or which he commissioned us to draw for him: plans [probably both city maps and ground

$72 \quad$ Armenini 1587 , pp. 64-65. Armenini's testimony should be handled with some care: it was published and probably written thirty years after the fact, and his memory was not quite accurate: witness his locating the Fuggers in Antwerp instead of in Augsburg; and there is no other indication that Strada visited Spain after his stay in Rome in the mid-1550s. 
plans of individual buildings], temples, medals, [triumphal] arches, columns, statues and other very ancient things from various periods that were found in that City, but in particular those that were the most remarkable and the most perfect of all... ${ }^{73}$

'Cose assai antiche': a large part of the material Strada collected referred to relics of the civilization of ancient Rome. The finished drawings of Greek and Roman coins produced on behalf of Fugger or included in Strada's other numismatic albums were copied after Strada's own sketches, the fruit of his study of the coins he had been able to examine on his travels in Germany, France and Italy. At least in part these sketches were taken directly from the original material preserved in the cabinets of Strada's erudite patrons, colleagues and friends resident in Rome at the time [above, Ch. 3.3, Figs. 3.26-3.33]. ${ }^{74}$ In addition to the numismatic drawings Strada also copied inscriptions, or rather had them copied from the syllogae or the albums of drawings in the collections of local humanists or his fellow antiquaries and artists.

One of the artists concerned was Giovanni Antonio Dosio, who had brought together an ample documentation of the classical remains of the Urbs, preserved in several volumes of drawings and transcriptions. From these albums Strada selected those altars, epitaphs etc. of which he did not yet possess an illustration, and Dosio provided him with copies of these [Figs. 11.14-11.15]. ${ }^{75}$ Such material was drawn upon for the huge lost corpus of inscriptions Strada intended to publish. According to its description in the Index sive catalogus, the list of those manuscripts prepared in his studio which Strada planned to have printed, this epigraphic corpus consisted of six volumes, presenting in all 5718 inscriptions, from Europe, Asia Minor and Egypt, and an additional volume of miscellaneous inscriptions. Most of these inscriptions-not only the 'Asian' and 'Egyptian' ones - Strada had copied from earlier drawings or transcriptions he had found in the collections he studied, rather than from the originals. ${ }^{76}$

73 Ibid., pp. 180, talking about the documentation of Raphael's Vatican Loggia Strada had commissioned: 'Et a questo agente ch'io dico, se ne fece un'altra copia, la quale dopo non molto tempo egli medesimo la portò in Spagna alla gran Corte del Re Filippo, con altri dissegni, che tuttavia comperava, et ch'era in commissione a noi per esso a dissegnar piante, tempii, medaglie, archi, colonne, statue, et altre cose assai antiche, che si sono ritrovate per quella Città in diversi tempi, che però erano delle più notabili, et più perfette dell'altre'.

74 Jansen 1993(a).

75 Above, Ch. 11.1.

76 Index sive catalogus, nr. 3; the relevant entry printed in Jansen 1993(a), pp. 238, where Strada's activity as an epigrapher is briefly discussed (pp. 221-226). 
Though some of the classical sculptures preserved in the Vatican, in the collections of the local patricians and the prelates resident at the Papal court probably were recorded on the spot, in many cases even such items were reproduced from extant earlier drawings (of which a great many were circulating), and occasionally even from prints. This is evident from Strada's Vienna album Antiquarum statuarum (= Codex miniatus 21,2, already described above). As its title implies, it documents antique full-length statues. It is composed of some hundred and seventy rather uninspired copies, executed in Strada's own workshop, after examples from the files of images Strada had acquired and commissioned during his stay in Rome, and gives some impression of the quantity and the character of the material he had brought together [above, Figs. 13.43-13.46]. Many of these copies were derived from graphic prototypes which were copied also in the albums of other antiquaries and artists, and often finally found their way into print. ${ }^{77}$ Drawings directly sketched after the object itself were presumably only commissioned when no acceptable design of a given object was readily available. ${ }^{78}$ Two rather more elegant sheets preserved in the miscellaneous selection of relics from Strada's Musaeum, also in Vienna, show a few male statues in their unrestored state: these likewise were the results — or were based on the results — of Strada's acquisition campaign of 1554-55..$^{79}$ [Fig. 13.72-13.73]

The same album also includes a series of pages of precise drawings of antique portrait busts [Figs. 12.5, 12.16-12.17 and 13.74-13.77]. Like most-though not all —of the items included in the Antiquarum statuarum, these busts are all shown in a restored state. ${ }^{80}$ This implies that they represent a subsequent stage of reception of the antique originals: applying both antiquarian and artistic criteria, Strada provided a reconstruction of the original which made it both more readable and - doubtless of great importance- suitable as a model or example for its reproduction and subsequent use in contemporary decorative schemes. Examples are his own house and the studioli of Hans Fugger and Jan Šembera Černohorský z Boskovic discussed and illustrated in Chapter 12.4.2 [Figs. 12.14-12.15].

These drawings provided part of the raw material used for the production of the two sets of drawings of Roman portrait busts from Strada's workshop that have recently been identified in the Kupferstich-Kabinett in Dresden. One of these, K.-K. Ca 74, is a single volume containing hundred and ninety drawings

77 ÖNB-Hs, Cod. min. 21,2; cf. above, Ch. 13.6.3.

78 Thus the drawings of the statues Strada supplied to the Munich Antiquarium (above, Ch. 12.2.2, Figs. 12.01-12.04) presumably were based on sketches Strada himself had made on the spot.

79 ÖNB, Cod. min. 21,3, fols. $55^{-56}$.

80 önB, Cod. min. 21,3, fols. 61-70. 

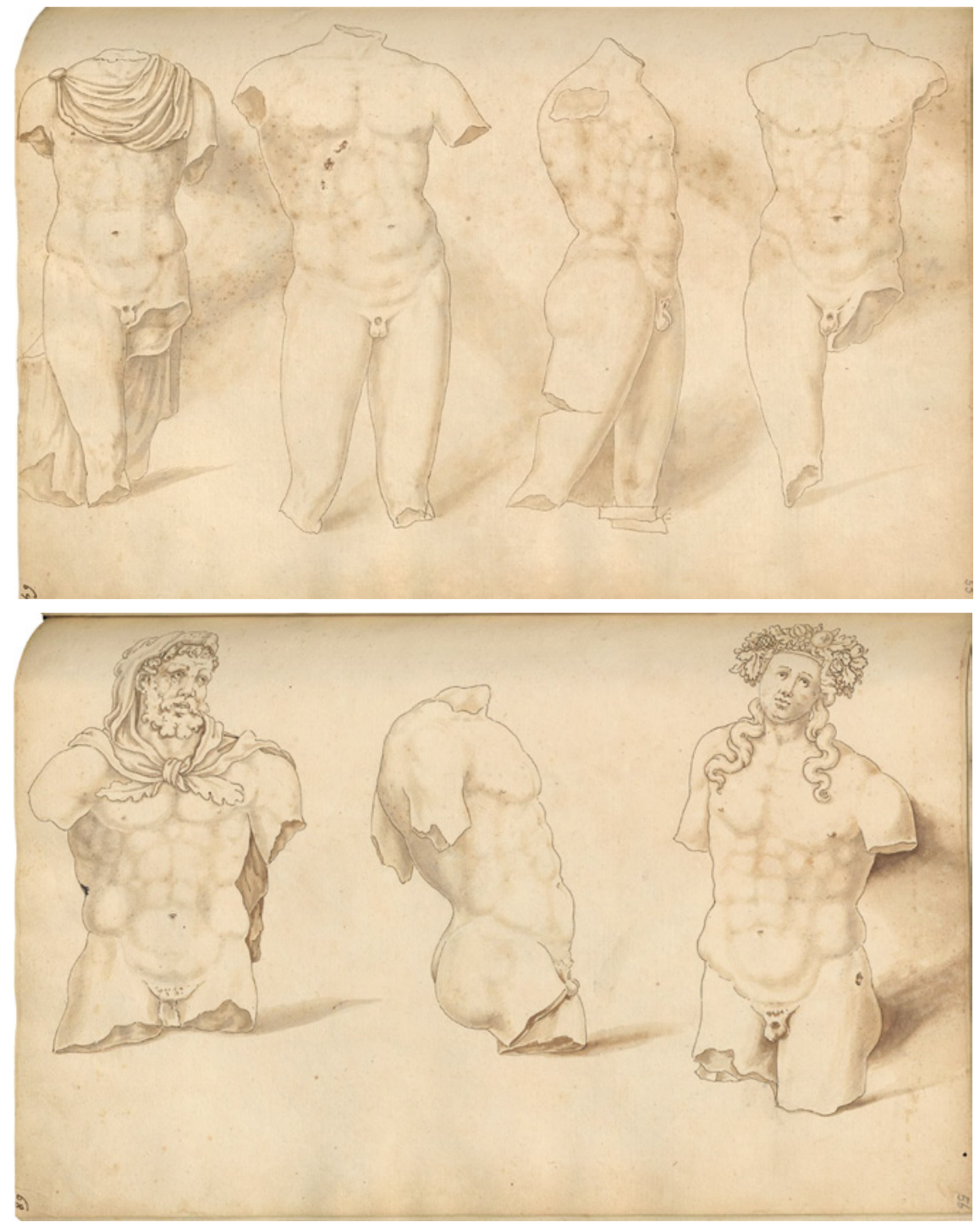

FIGURES 13.72-13.73 Codex miniatus 21,3, fols. 338/55r. and 339/56r.: workshop of Jacopo Strada, documentary drawings of antique male statues.

of portrait busts of Roman Emperors and usurpers and their dependants [Fig. 13.78], as well as some herms of literary figures and some miscellaneous objects, the most interesting of which is a herm in Egyptianizing style. Strada had left the album behind after a visit to the Elector August of Saxony at Annaburg Castle at Torgau, in order for the Elector to have it copied. Though the copy was made, the book was never returned to Strada, and it is mentioned in an 

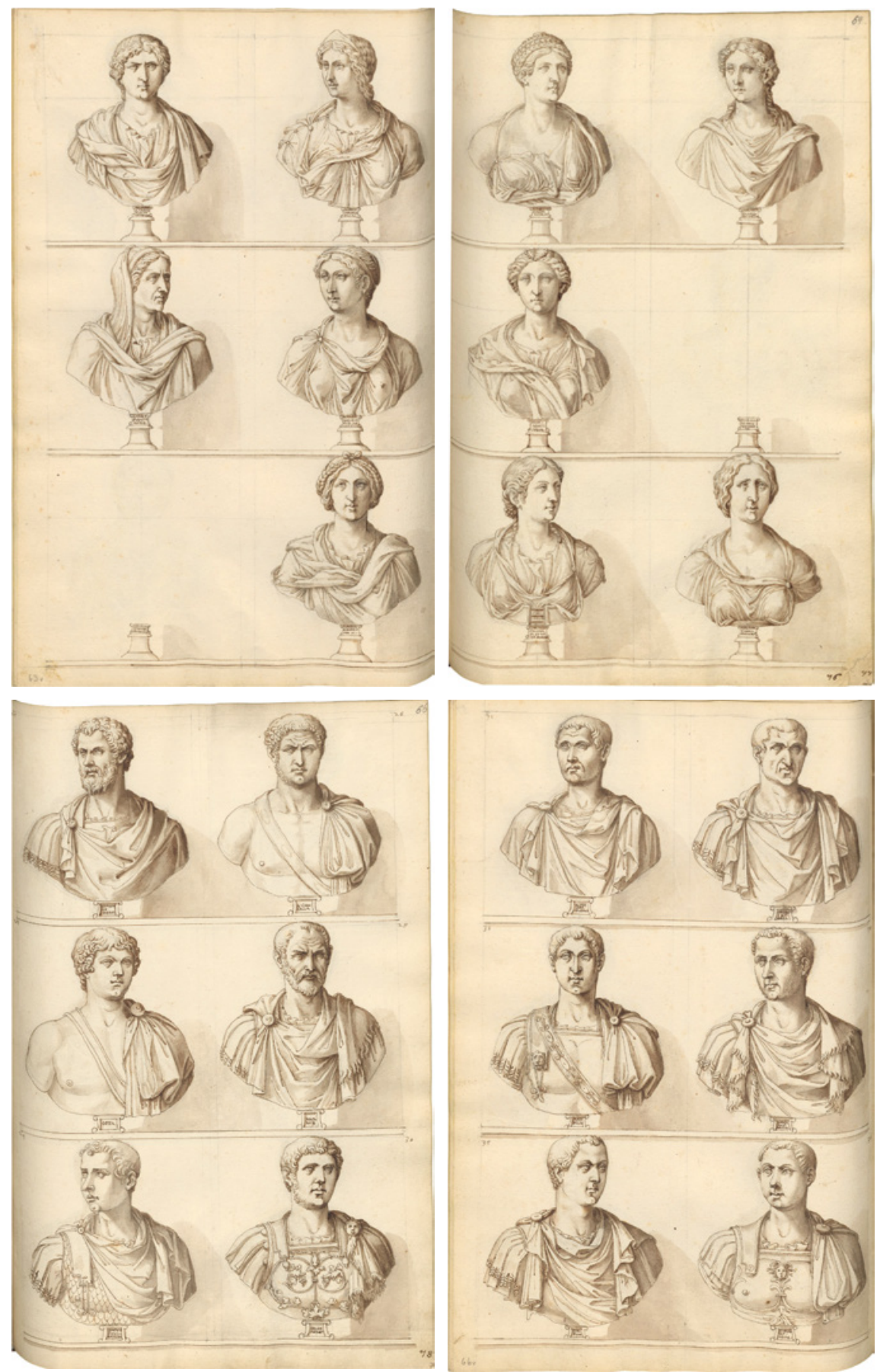

FIGURES 13.74-13.77 Codex miniatus 21,3, fols. 63v., 64r., 66r. and 66v:: Jacopo Strada or workshop, documentary drawings of female and male Roman portrait busts, restored versions, pen and wash. 


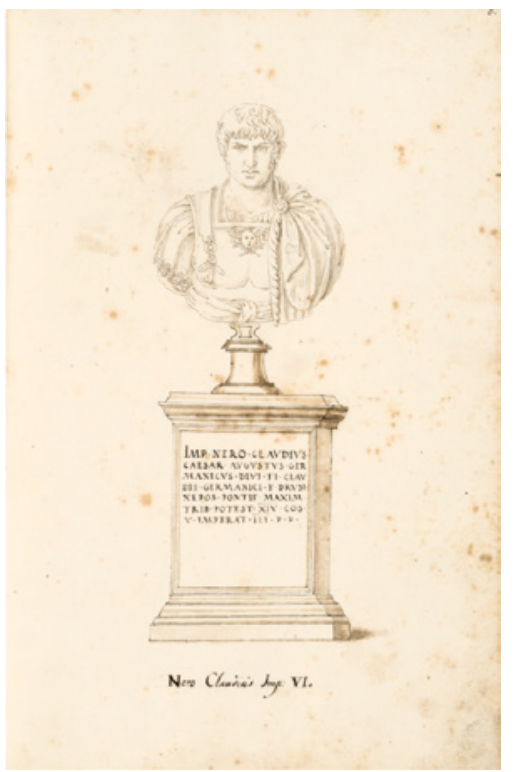

\section{SERIES CON IINVAIA}

ONNIVM IMPERATORVMTAM LATINORVM.

QVAMGRACORVM SIVE CONSIANTINOPOUTANORMM

E ANTIQVIS MLRMORIBV FTNVM SMATIBVS FIDE,

LISSIME ET EXACTISSIMEAD VIVYM EXPRESSORVMC.

ETMUSV DENEATORNM INGIFENS ACIVLO CNSSAE

PRIMO IMPERUTOREET HNIENS IN VUTMO CRAECORVM

CAESARE CONSTANTINO XV PALEOLOGO.

ADDITA SVNT SINGVUS IMPERTYORINSH OCLA

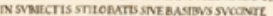
TTAUITE DESCARA

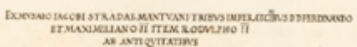

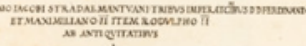

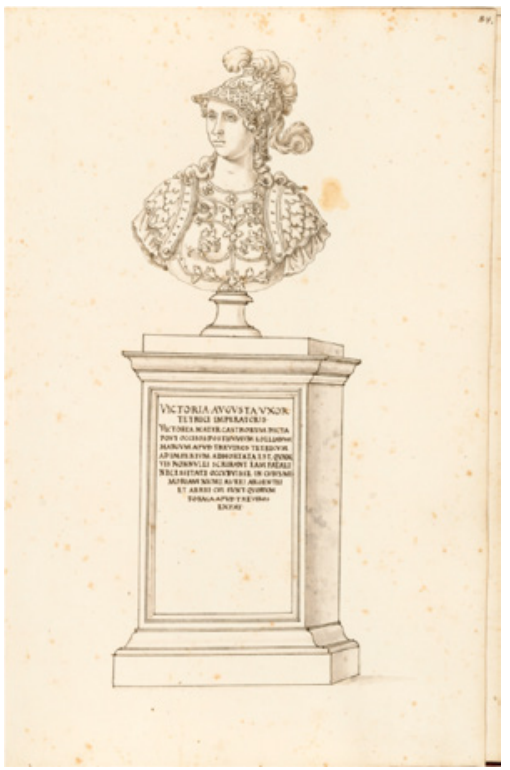

FIGURE 13.78 Kupferstich-Kabinett.

Jacopo Strada,drawing of a portrait bust of Nero; Dresden,

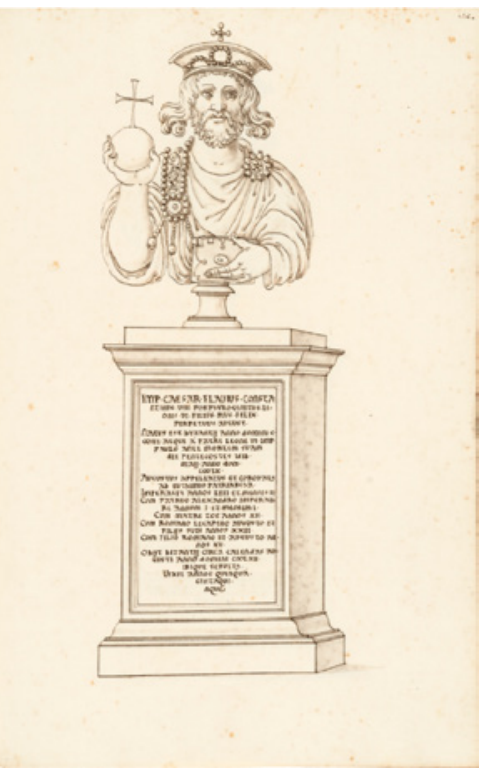
ings of imperial portrait busts and drawings of busts of Victoria Augusta, consort of Tetricus, and of Constantine virI Porphyrogenitus; Dresden, Kupferstich-Kabinett. 
inventory of $1587 \cdot{ }^{81}$ The draughtsmanship of this seems of somewhat higher quality as that of the other item, K.-K. Ca $75^{-77}$, which consists of three volumes in red satin bindings. It appears to have been presented to Elector Christian I by Ottavio Strada, shortly after his father's death..$^{82}$ [Figs. 13.79-13.81] This presents a complete series, similar to Strada's numismatic albums, of Roman imperial portraits from Julius Caesar up to the last Byzantine Emperor, here derived - or pretending to be derived - from Roman portrait busts. Each bust is placed on a pedestal on which an 'elogio' or brief life is inscribed in the guise of an antique inscription.

These volumes, especially the three-volume series, allow us to form an impression for a planned publication Strada described in his Index sive catalogus and in his letter outlining his programme to the Antwerp printer Christophe Plantin: this likewise is a series of portraits of Roman Emperors and Empresses, showing their portrait busts engraved in a copper plate, above a standard pedestal which could be a woodcut, in which a space would be left open for an 'Ellogio' or brief summary of their lives composed in Roman capitals in lead type. Ottavio Strada's manuscript volume in Florence gives some idea of what the finished product was intended to look like..$^{83}$

The Index sive catalogus makes clear that Strada had not limited his acquisition of drawings of classical sculpture to those documenting full-length statues and portrait busts. It also mentions a 'book in which are drawn all sort of figures [statues in the round], tables [reliefs] and old, well-wrought and sculpted

81 I am grateful to Gudula Metze and Thomas daCosta Kaufmann to have drawn my attention to the material in the Dresden Kupferstich-Kabinett. The material has been first published in Melzer 2010, pp. 130-138; a concise survey in Jansen/ Metze 2018. SKD-KK, inv. nr. Ca 74: Imperatorum Romanorum ac eorum coniugum, liberorum et affinium, tum etiam virorum illustrium, poetarum et philosophorum, praecipue qui in Graecia universa floruerunt, Imagines ad vivam expressae, quae Romae ac diversis in locis Europae inveniuntur, è marmoribus desumptae una cum eorum Elogiis expressis. Tomus Primus. Though Strada's name is not mentioned in the volume, in view of its make-up and its draughtsmanship there can be no doubt of its provenance from Strada's workshop. The copy is preserved in Dresden, Sächsische Landes- und Universitätsbibliothek, Handschriftensammlung, Mscr. Dresd. App.187 [= KA 210] (formerly Kupferstich-Kabinett Ca 73).

82 SKD-KK, inv. nr. Ca 76 (vol. I), Ca 77 (vol. II) and Ca 75 (vol. III): Series continuata omnium Imperatorum, tam Latinorum, quam Graecorum sive Constantinopolitanorum, ex antiquis marmoribus et numismatibus fidelissime et exactissime ad vivum expressorum, et manu delineatorum; incipiens a C. Iulio Caesare primo Imperatore, et finiens in ultimo Graecorum Caesare Constantino XV Palaeologo. Addita sunt singulis Imperatoribus elogia in subiectis stilobatis sive basibus succincte et breviter descripta. Ex Musaeo Iacobi Stradae Mantuani, tribus Imperatoribus, D.D. Ferdinando et Maximiliano II, item Rodulpho ii. ab antiquitatibus. Cf. Melzer 2010, pp. 133-136.

83 Index sive catalogus (Appendix D), nr. 6; Biblioteca Laurenziana in Florence, Med. Palat. 235a-b; illustrated, but not discussed, in Marx 2007, pp. 213-214, figs. 52-53. 
graves [sarcophagi] and monuments in Rome, Florence, Venice, Mantua and elsewhere in Italy'. One imagines this to have been a careful selection of the best examples of Roman classical sculpture available, based on the drawings Strada had acquired during his travels. ${ }^{84}$

\subsubsection{Drawings of Architecture}

In addition to the seven volumes of inscriptions the Index sive catalogus lists several items that Strada acquired or commissioned in a similar manner, either during his sojourn in Rome in the 155 os, or later, during his trips to Venice in the 1560 s. Some of these relate to ancient monuments and architecture. Though with Serlio's 'literary remains' and the drawings from Giulio and Perino's estates Strada had already acquired an imposing fund of documentation of ancient architecture, he remained eager to supplement this with drawings of even greater precision, and of course with designs documenting the latest discoveries. It is interesting to note that it were these, the architectural drawings, which he explicitly claimed to have made himself:

Also several books, drawn by hand, of buildings and architecture, in which I took particular delight, and which I myself drew after most ancient buildings, and which I reduced to the same scale as much as possible; each [annotated] with the measurements of their parts. ${ }^{85}$

During his stay in Rome in $1553^{-1556}$ Strada doubtless occasionally drew and measured some ruins himself, but he was too strenuously occupied to have done this on a grand scale: presumably he left the collecting of evidence on the spot and the execution of preliminary sketches to the 'valenti giovani' he employed. ${ }^{86}$ When he talks about having made these drawings himself, I think this means that he translated the information provided by these rough sketches and the noted measurements into finished, precise drawings fit to be

84 Index sive catalogus, (Appendix D), nr. 36; cf. Doc. 1578-08-13.

85 Index sive catalogus (Appendix D), nr. 34 .

86 The execution of precise measured drawings of triumphal arches, temples, theatres, baths and other relics of Antiquity posed complex logistic problems, as is illustrated in a passage from the introduction to Philibert de l'Orme's Architecture (Rouen 1648, fol. 131r). From the account of the difficulties he encountered while engaged on his survey of some of the Roman ruins in the 1540 s, it is clear that its success was dependent on the availability not only of the necessary instruments, but also of the necessary assistance: '<...>ce que ie ne pouvois faire sans quelque nombre de d'hommes qui me suyvoient, les uns pour gagner deux Iules ou Carlins le jour, les autres pour apprendre, comme estoient Ouvriers, Menuisiers, Scarpelins, ou Sculpteurs et semblables, qui desiroient cognoitre comme ie faisois, et participer du fruit de ce que ie mesuroi <... > (Orme 1567, livre V, Chap. I, quoted and discussed in Nesselrath 1984-1986, p. 137). 

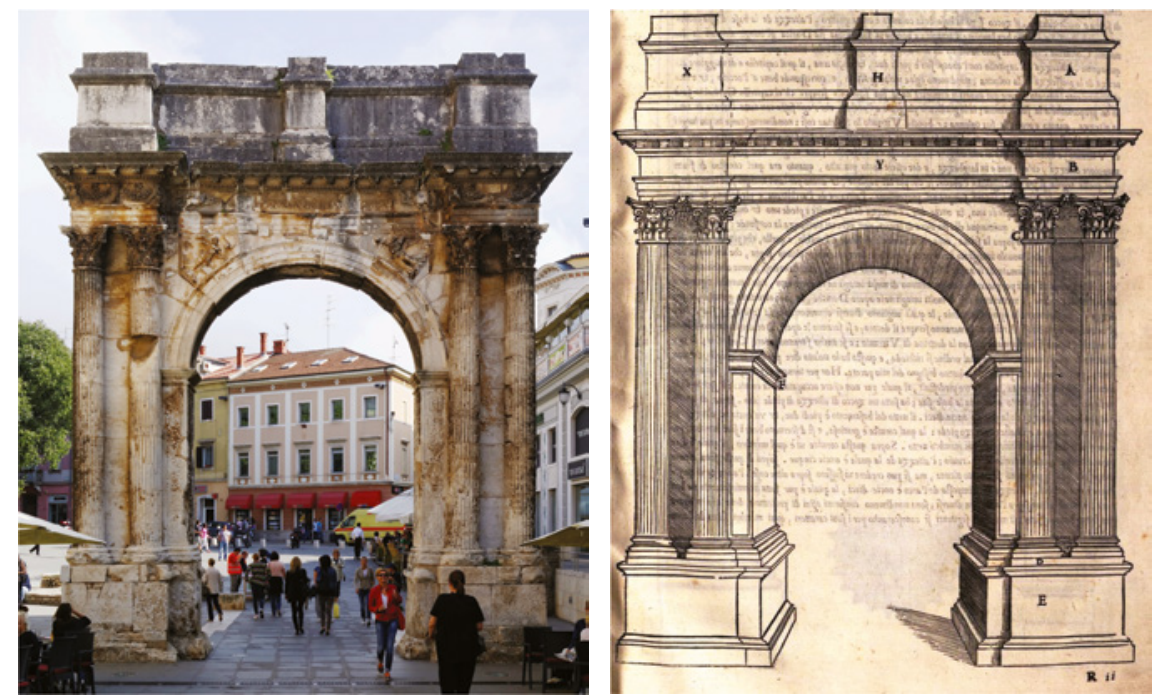

FIGURE 13.82 The Arch of the Sergii at Pula.

FIGURE 13.83 Sebastiano Serlio, The Arch of the Sergii at Pula, woodcut from his Terzo libro, Venice, 1544 .

incorporated into his libri di disegni or to be engraved and published, as he indicates in his description of these volumes in his letter to Christophe Plantin just mentioned. ${ }^{87}$

A single drawing in a codex in the Vatican Library published by Hubertus Günther helps to illustrate Strada's procedure [Figs. 13.84-13.85]. This drawing is based on a measured sketch of the Arch of the Sergii in Pula in Dalmatia [Fig. 13.82] included in the so-called sketchbook of Michelangelo in the Musée Wicar in Lille, which is nowadays attributed to Raffaele da Montelupo and itself goes back to earlier sketches from the circle of Antonio and Giovanni Battista da Sangallo [Fig. 13.86]..$^{88}$ The Vatican version can be attributed to Strada on the basis of the comment in his hand, and of the resemblance of its style to Strada's autograph design for the Munich Antiquarium [above, Fig. 8.15]. Strada not only uses the same measure, the piede antico divided in 32 once, but also almost literally transcribes the legend of the Lille drawing. ${ }^{89}$

87 Doc. 1578-08-13: 'Poi varii libri di dissegni per intaliare in ramè. Prima di cose di Architetura (della quale sempre mi son delettato e deletto), cose messe insieme e ritratte dal Anticho, che veramente che le stampasse sariano di grande Utilita al mondo'.

88 Biblioteca Vaticana, Cod. Rossi, 618, f. 42r; cf. Günther 1988, Fig. VI/10, pp. 208-211.

89 The drawing is itself a copy after Antonio or Giovanni Battista da Sangallo: Günther 1988, pp. 208-211. The Lille sketchbook is attributed to Raffaello da Montelupo, with additions by Aristotile da Sangallo (Nesselrath 1983). 


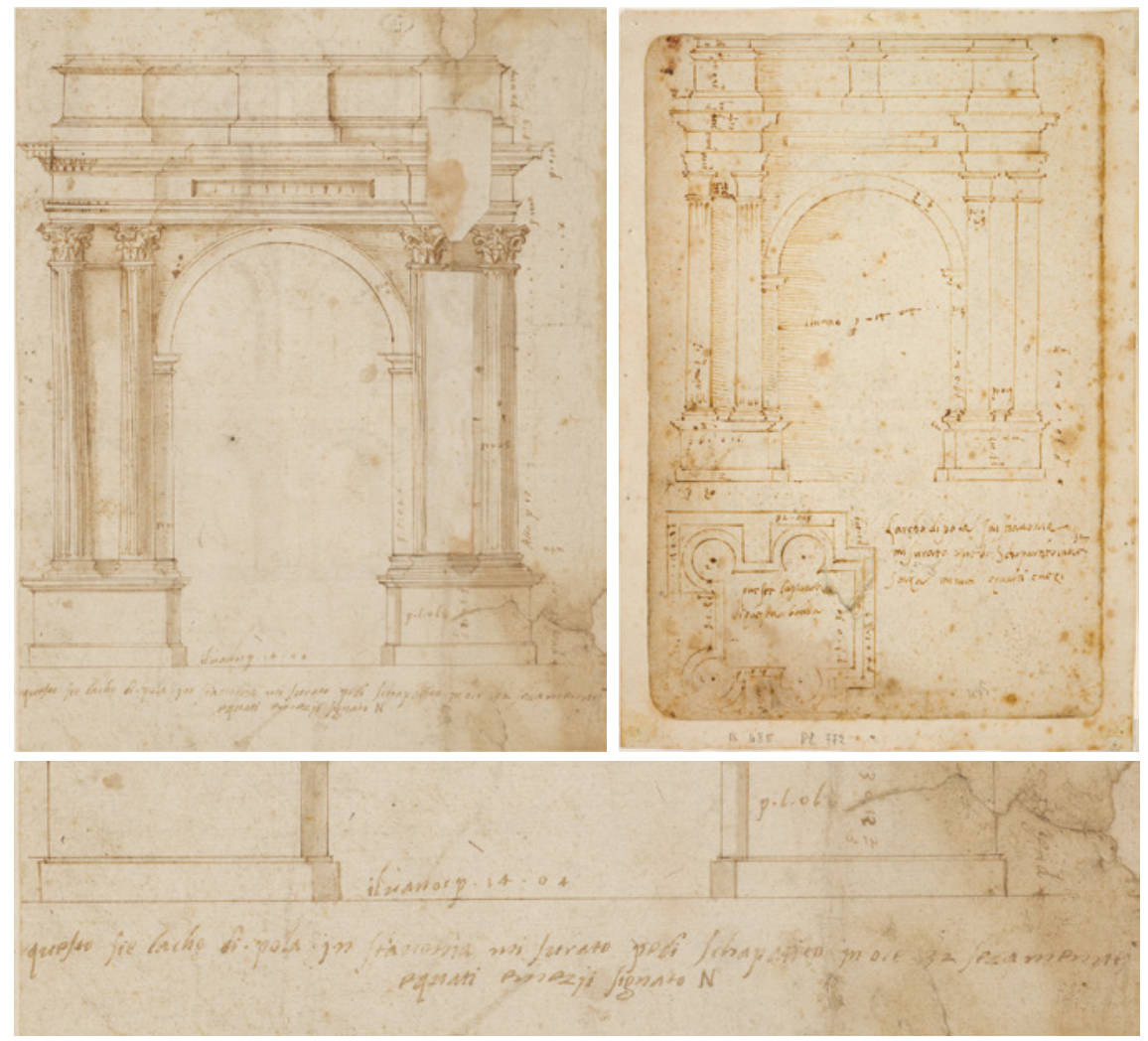

FIGURES 13.84-13.85 Here attributed to Jacopo Strada, the Arch of the Sergii at Pula, pen and wash, Rome,Biblioteca Vaticana, Cod. Rossi 618, fol. 42r; and detail of the inscription; (C) 2018 Biblioteca Apostolica Vaticana.

FIGURE 13.86

Attributed to Raffaele da Montelupo, Arch of the Sergii at Pula, Lille, Musée Wicar, so-called Michelangelo Sketchbook, nr. 772.

But whereas the latter is a quickly executed sketch, Strada worked out sketch and the measurements given into a finished architectural design drawn with ruler and compasses and enlivened by a light wash. Architectural details such as the capitals and the fluting of the Corinthian columns-not shown in the existent sketches - are carefully rendered, possibly inspired either by Serlio's woodcut of the arch included in the Terzo Libro [Fig. 13.83] or directly by its example among Serlio's papers. Moreover the examples used are adapted to the author's own architectural convictions: thus the central pedestal in the attica is made much wider than in the example, and the cornice, not worked out in the example, is interpreted with an egg-and dart moulding, rather than with the consoles present in the actual building and shown in Serlio's woodcut. Probably most of the drawings in the volumes Strada wished to publish had 
been prepared in a similar manner: as far as possible Strada would have reduced the drawings to the same scale, and have recalculated the measurements annotated in his models to one common unit. This may well have been the same piede antico used in the Lille sketchbook, and taken over in Strada's drawing: Strada's pretension to archaeological erudition would have made him prefer the piede antico in any case, and he was most familiar with the ancient foot as used in Serlio's circle, where it was divided into thirty-two once - as in the Lille drawing itself. ${ }^{90}$

Often Strada compared several drawings documenting the same monument in order to come up with as correct a version as was possible. At least that is what he implies in his preface to his edition of Serlio's Settimo Libro, where he described the great quantity of architectural drawings he had been able to bring together:

It is certainly true that I possess many doubles, and that gives me great satisfaction, being able to compare them with respect to their measurements - to such an extent that, for those things I will give you, there is no need to go and measure them again in Rome or elsewhere, because they will be excellent in every respect, and conforming exactly to the originals. ${ }^{91}$

The drawing in the Vatican codex probably made part of Strada's own files, rather than of a finished manuscript intended for publication: while its verso shows the Amphitheatrum castrense, its recto gives-apart from the Arch of the Sergii-the elevation of the courtyard of the Palazzo Farnese. Yet it gives an impression of what such a manuscript might have looked like, and of the degree of precision that a printed version might have attained to. It may also be of some help in identifying other sheets from Strada's studio. Had some of these volumes been preserved in their entirety in a public collection, their provenance, and hence their authorship, probably would have been known, so it must be assumed that they either were lost, like most of Giulio's architectural drawings, or that they have been cut up and dispersed in later times. ${ }^{92}$

$90 \quad$ Günther 1988, pp. 225-231.

91 Serlio 1575, fol. A iiii-r.: 'E ben vero che più d'una cosa doppia mi truovo, e questo mi è di una grandissima sodisfatione, per conferirle insieme per rispetto delle misure: A tale, che le cosa ch'io vi darò, non accadera ch' le andiate à rimisurare à Roma, ò altrove: che saranno di tutto punto eccellenti, e giusto alle originali'.

92 Some of the originals - or volumes presenting copies taken from among these-may have been provided to Strada's patrons. Thus the Ficklersche Inventar of the Munich Kunstkammer mentions two books of drawings of ancient architecture which probably were acquired from Strada: nr. 105 (102): 'Etliche stuck alt Römischer Gebew, thails in grundt 


\subsection{3 'Magnifica colonna coclida istoriata'}

Thanks to Strada's acquisitions of Serlio's, Giulio's and Perino's materials and his acquisitions and commissions in Rome, Strada's documentation must have included drawings and prints of most or all of the principal ancient remains of the Urbs, including famous monuments such as the Colosseum, the Pantheon, the Basilica of Maxentius, the Arches of Titus, Septimius Severus and Constantine, the Septizonium, the Baths of Caracalla and Diocletian, the Castra Pretoria and the Mausolea of Augustus and Hadrian. But the only antique monuments of Rome which are individually mentioned in Strada's papers are three monumental columns the shafts of which were decorated with figurative spiral friezes in low relief, dedicated in honour of the Emperors Trajan and Antoninus (Marcus Aurelius), both in Rome, and Theodosius (Arcadius) in Constantinople. According to his descriptions in the Index sive catalogus and his letter to Christophe Plantin Strada possessed series of drawings of the spiral relief friezes of these three columns, each set of which was, as he phrased it, 'ridotta in un libro', 'bound as a book. ${ }^{93}$

The reception of Trajan's Column in the Renaissance has been the subject of detailed research. ${ }^{94}$ The production of a survey of a 'colonna coclide istoriata' such as the Trajanic column, in particular of its upper part, obviously was no easy task; yet this is what was done some time before 1506 by Jacopo Ripanda, who slowly descended along its shaft in a basket suspended from its top. ${ }^{95}$ There are some indications that this feat was repeated by Giulio Romano

gelegt, thails wie die gewesen, und thails noch sein, in Regal, und weiß Copert' and (less likely) nr. 106 (103): 'Architectur buech etlicher Gebew, Triumphpögen, Portiken, und anderer Römischer gebew in kupffer gestochen, thails von freyer handt gerißen'. München, BSB-HS, Cgm 2133 fol. 8v-9r / 2134 f. 8r; transcribed in Diemer 2004, p. 47; Diemer/Diemer 2008, pp. 34-36.

93 Index sive catalogus (Appendix D), nrs 37, 40 and 41; paraphrased in Strada's letter to Plantin, Doc. 1578-08-13): [37] 'Un libro dove sta ritratta tutta la colonna Trajana ch'è in Roma p [er] tutta la forma della colonna di fuori et di dentro et poi le historie in un libro, sonno foli. 150. In questo libro sonno tutte li vestimenti Civili et milittari si de Romani corne anche di altre natione Barbari dove Traiano Imperadore combatette. ...; [40] La colonna di Theodosio Imperadore che sta in Constantinopoli ridotta in un libro passa 100 fol. Reali aperti; questa l'o fatta dessignare à spesa mia in Constantinopoli]'; [41] 'La Colonna Antonina di Roma ridotta in un libro simile alla Traiana sunominata; questa fu dessignata ad instanzia mia in Roma'.

94 Becatti 1960; Agosti/ Farinella 1984, in particular part 1, 'Un monumento: La Colonna Trajana, per esempio', pp. 390-427; Arasse 1984; Agosti/ Farinella 1985; Settis/ La Regina/ Agosti/ Farinella 1988; Heenes 2017.

As told by Raffello Maffei (Volterrano), Rerum urbanorum commentarii, 1506: 'Floruit item nunc Romae, Jacobus Bononiensis, qui Trajani Columnae picturas omnes ordine delineavit, magna omnium admiratione, magnoque periculo circum machinis scandendo'; cited in Arasse 1984, p. 15 and note; quoted in Agosti/Farinelli 1984, p. 400. 

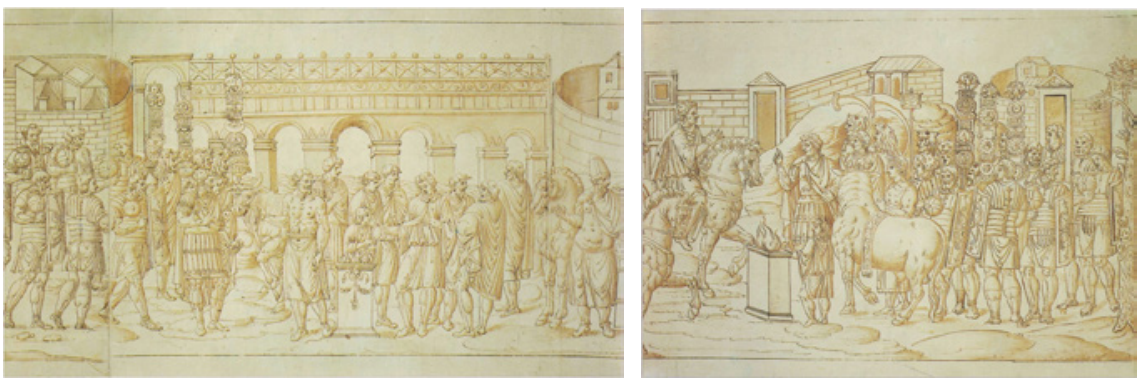

FIGURES 13.87-13.88 Strada purveyed this or a similar rotulus illustrating the entire frieze of Trajan's Column to Vilém z Rožmberk; private collection.

and his assistants: at least such is implied in the preface of the first complete series of prints after the frieze, engraved under the supervision of the painter Girolamo Muziano and published in 1576 with a scholarly commentary composed by the Spanish priest and antiquary Alfonso Chacón [Ciacconius]; a series which itself, however, was based on Ripanda's survey ${ }^{96}$ In view of Giulio's strong affinity with classical art, and his use of elements from the Trajanic column in his own works, this is not impossible, though it is equally likely that he too contented himself with reinterpretations of Ripanda's drawings. In either case Strada may have possessed and used a set of copies immediately derived from Giulio's version; it is unlikely that Strada would have thought it worth the trouble and expense of producing a new series drawn directly from the monument (the length of the frieze is about 200 meters!) when such drawings were readily available, as is indicated by the number of series dating from the sixteenth century that have survived. ${ }^{97}$

$96 \quad$ Historia utriusque belli Dacici, a Trajano Caesare gesti, ex simulachris quae in columna eiusdem Romae visuntur collecta. Auctore F. Alfonso Ciaconio, Roma 1576; cf. Arasse 1984, pp. 15-16, n. 23: 'Dans l'introduction de l'édition de 1576, Chacon fait une référence assez vague aux copies de la colonne faites par Raphäl et ses disciples, Giulio Romano et Polidoro da Caravaggio. La réédition de 1616 est plus précise dans la mention de Giulio: 'Descripserat olim Julius Romanus, pictor egregius, quem Raphaelis aequalem fuisse scimus. Quam descriptione secutus Mutianus, Alfonso Ciaconio eruditissimo viro, viam aperit ad ea esponenda latine".

97 The earliest extant version, by or after Ripanda, is preserved in Rome, Biblioteca dell'Istituto Nazionale di Archeologia e Storia dell'Arte, inv. nr 7459. It is significant that even Muziano's edition was based not on new original drawings, but directly or indirectly derived from Ripanda's series. In fact some of Ripanda's inaccuracies still show up in Reinach's famous repertory of Greek and Roman reliefs (Reinach 1909-1912, cited in Agosti/ Farinelli 1985, p. 1117). Other sets of copies dating from the sixteenth century in Rome, ibid., inv. nr. 61283; and in Modena, Galleria Estense (all as rotuli). 
Such sets of drawings of Trajan's Column were quite popular, and not least with Strada's patrons: a copy in the form of a book, now in the Österreichische Nationalbibliothek, but originally at Ambras, may well have been the copy Strada mentions in his Index sive catalogus, acquired by Archduke Ferdinand II of Tirol after Strada's death-if not before [Fig. 13.89-13.90]. A similar copy, this time in four volumes, is mentioned in an inventory of the Munich Kunstkammer of 1598, together with a set of drawings after the frieze of the column of Marcus Aurelius. Perhaps these had been commissioned by Duke Albrecht $\mathrm{V}$ of Bavaria from Strada together with a similar set of drawings of the Column of Theodosius in Constantinople, but it is more likely that the drawings of the Theodosian column (in fact it was the column dedicated to Arcadius) were intended to complement the sets of drawings of the Columns of Trajan and Marcus Aurelius which Strada earlier may have purveyed to Fugger. ${ }^{98}$ Finally Strada supplied a copy to Vilém z Rožmberk, the Czech magnate to whom he had dedicated his edition of Serlio's Settimo Libro. In this case the sheets had been pasted together so as to form a continuous scroll, rather than a codex: '<...> die Columna Trajana, die ich E.G. vorlengst presentiertt hab, nemlich des kästla mit den vieren rollen<...>'.99 This rotulus must have been very similar to the scroll from a private collection which was exhibited at the Institut Français at Florence in 1984 [Fig. 13.87-13.88]: technique and style of drawing of this set is so close to Strada's numismatic drawings that a tentative attribution to his
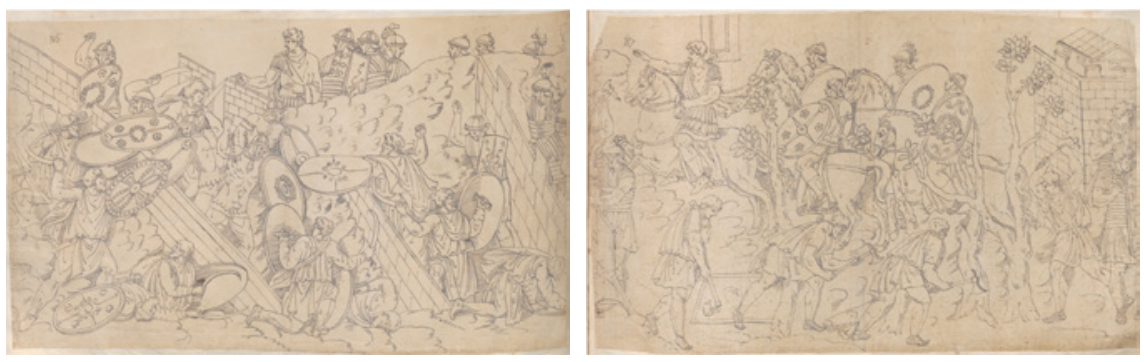

FIGURES 13.89-13.90

The Column of Trajan in images from the Ambras manuscript, probably purveyed by Jacopo Strada; Vienna, Österreichische Nationalbibliothek.

98 ÖNB-Hs, Cod. 9410. In the older catalogues this volume precedes the description of the numismatic volumes by Jacopo and Ottavio Strada. The Munich copies are mentioned in Diemer/Diemer/Sauerländer 2008, 1, p. 58, nr. 153 (Marcus Aurelius) and p. 66, nr. 183 (Trajan); on the drawings of the Column of Theodosius, not included in the inventory, see below.

99 Doc. 1573-12-18; Strada wished to borrow Rožmberk's copy to consult it for his polyglot dictionary, which indicate that at that time he did not possess a copy of his own; perhaps he took this opportunity of preparing the copy in the form of a book mentioned in the Index sive catalogus. 

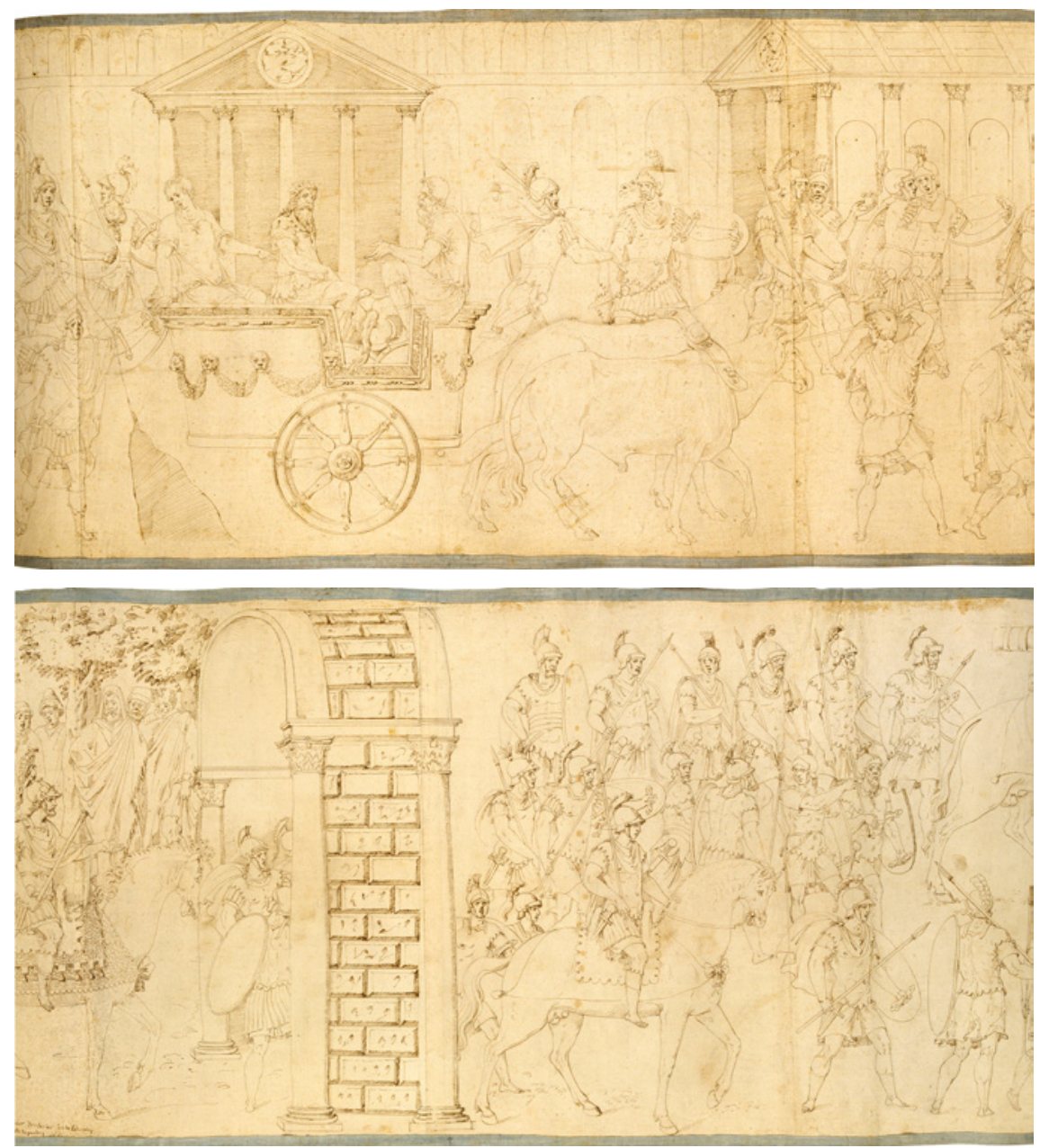

FIGURES 13.91-13.92 Attributed to Battista Franco, section of a set of drawings documenting the Column of Theodosius in Constantinople; Paris, Musée du Louvre.

workshop is warranted. Two other sets have been preserved in Rome and in Modena. ${ }^{100}$

It is very unlikely that Strada would have thought it worth the trouble and expense of producing a new series drawn directly from the Column of Trajan, if

100 Exhibited in Florence in 1984, with a valuable catalogue [Arasse 1984], including pp. 13-24 a careful description by Cathérine Monbeig Goguel, 'Du marbre au papier: de la spirale verticale à la bande horizontale: A propos d'un dessin du seizì̀me siècle d'après les basreliefs de la Colonne Trajane'. The rotulus consists of two sections of ca 7,50 m. each. Further sets are in Rome, Biblioteca dell'Istituto Nazionale di Archeologia e Storia dell'Arte, inv.nr. 61283 (three rotuli), and in Modena, Galleria Estense. 
drawings were readily available in Rome: Strada's drawings of this monument doubtless were derived from such earlier sources. But the Column of Marcus Aurelius was much less well documented and Strada may well have needed to organize the preparation of a complete survey of the frieze himself. In his entry on this column he explicitly stated that these drawings, like those of the Column of Theodosius (in fact that of Arcadius) were made at his initiative and expense (a claim he omits when describing the drawings of Trajan's Column). If such a complicated operation indeed took place on Strada's instigation, this would only have been possible thanks to Fugger's strong financial backing: after all this required a well-managed team of draughtsmen and assistants as well as some considerable investment in scaffolding and/or machinery. Unfortunately the early reception of the Column of Marcus Aurelius has been less studied than that of Trajan's Column. ${ }^{101}$

Apart from the two Roman columns Strada also took pains to document the similar column erected in Constantinople by Arcadius, but finished and dedicated only after his death (408 AD) by his son, Theodosius II ${ }^{102}$ This latter fact may help to explain the regular confusion of this column with the one erected by Theodosius the Great in about 386, but destroyed in an earthquake in 1517: Strada and his contemporaries referred to the columns of Antoninus and Theodosius, rather than to those of Marcus Aurelius and Arcadius. Under its incorrect appellation the column of Arcadius, which remained standing until hit by an earthquake in the early eighteenth century, was well known to travellers. Strada had commissioned a set consisting of about hundred sheets of this column on behalf of Duke Albrecht V during his 1567 visit to Venice and Mantua, which was delivered in instalments between 1567 and early $1569 .{ }^{103}$ This implies either that Strada had gained access to a complete set of drawings of this frieze-perhaps in the possession of collectors such Giovanni Grimani or Cesare Gonzaga - or that he had these commissioned himself through his contacts in Constantinople, such as the Imperial diplomats at the Ottoman court with whom he had good contacts, or through trade connections in

101 The Census of Antique Works of Art and Architecture Known in the Renaissance refers only one print of a scene of the shaft, a Sacrifice of Marcus Aurelius, by León Davent printed by Lafreri in the Speculum Romanae Magnificentiae, and no drawings at all (http://census .bbaw.de; consultation 5 August 2017); I have never found references to sets of drawings of the frieze from the 16th century; but many scenes-such as the Victory inscribing Marcus' Triumph on an oval shield, halfway up — must have been very familiar to Renaissance artists.

102 Grigg 1977.

103 The sources mention instalments of 50 sheets and a later consignment of 45 sheets. Cf. Stockbauer 1865, p. 34: 'Um die Colonna Theodosii, sind 50 Bogen jeden zu v $11 / 2=$ v 75,-'; Busch 1973, pp 204,. 340-341, n. 85. 
Venice. In the relevant entry in the Index sive catalogus Strada claims that the drawings and an accompanying description were his explicit commission:

\begin{abstract}
Also the famous column of the Emperor Theodosius of Constantinople which exists in Byzantium, which I also had drawn and described in Constantinople, at my expense, in a book of hundred folii; with all the figures and histories that are sculpted and engraved in it. ${ }^{104}$
\end{abstract}

At the time he doubtless had made a second copy of the set for himself which he could afterwards offer for publication to Christophe Plantin. It has been suggested that the set offered to Plantin was executed, or its production supervised, by Strada's elder son Paolo, who had been sent to Constantinople with an Imperial Embassy in 1569. It seems more likely that Strada had commissioned his own copy at the same time, from the same draughtsman, and after the same model as that destined for Duke Albrecht V of Bavaria. It can be assumed that Strada would have had contacts in Constantinople before sending his son there. ${ }^{105}$ Like those of Trajan's column, the set of the Constantinople column was probably copied from an existing set, such as the one traditionally attributed to Battista Franco which is preserved in the Louvre as a rotulus mounted in a specially constructed table [Figs. 13.91-13.92]. That would not necessarily contradict Strada's statement that he had commissioned his version in Constantinople. ${ }^{106}$

104 Index sive catalogus, Appendix D, nr. 40; and Doc. 1578-12-15.

105 Strada's earlier contacts with Imperial diplomats in Constantinople included Vrančić, Rijm and Busbequius, from the latter of whom he obtained manuscript material, and can be assumed in the case of his neighbour in Vienna, Christoph von Teuffenbach (cf. above, Chapter 10.5). He sent his son Paolo to accompany Karel Rijm's embassy with the explicit purpose to learn Turkish and Arabic, to acquire antiquities-particularly Greek manuscripts - and to collect documentation of the various monuments of that ancient capital. On Rijm, see Stichel 199o. Paolo Strada's stay is documented in Strada's letters, for instance to Duke Guglielmo of Mantua (Vienna, 5 November 1569 , published in $J d K S$, XVI (1895), 2ter Teil, Reg. nr. 13998), and in requests to the Emperor on his son's behalf (HHStA, Staatenabteilung Türkei, I, 28, ff. 132r.-133v.) to which my attention was kindly drawn by Zweder von Martels.

106 A set of drawings could have remained in Constantinople. The set attributed to Battista Franco is in Paris, Louvre, Cabinet des Dessins, Fonds des dessins et miniatures, inv. nr. 4951; cf. Müntz 1881; Becatti 196o, pp. 111-150; Lauder 2009, pp. 301-303. These drawings appear to have been mounted as a rotulus only in the seventeenth century; the present table probably dates from the eighteenth century. I am very grateful to Cathérine Goguel to have drawn my attention to these drawings, and to have arranged for me to see them and discuss them with me. Arnold Nesselrath and, following him, Goguel, have proposed an alternative attribution to Giulio Romano, in which case it is likely that Strada's copies would have been based directly on Giulio's model. 

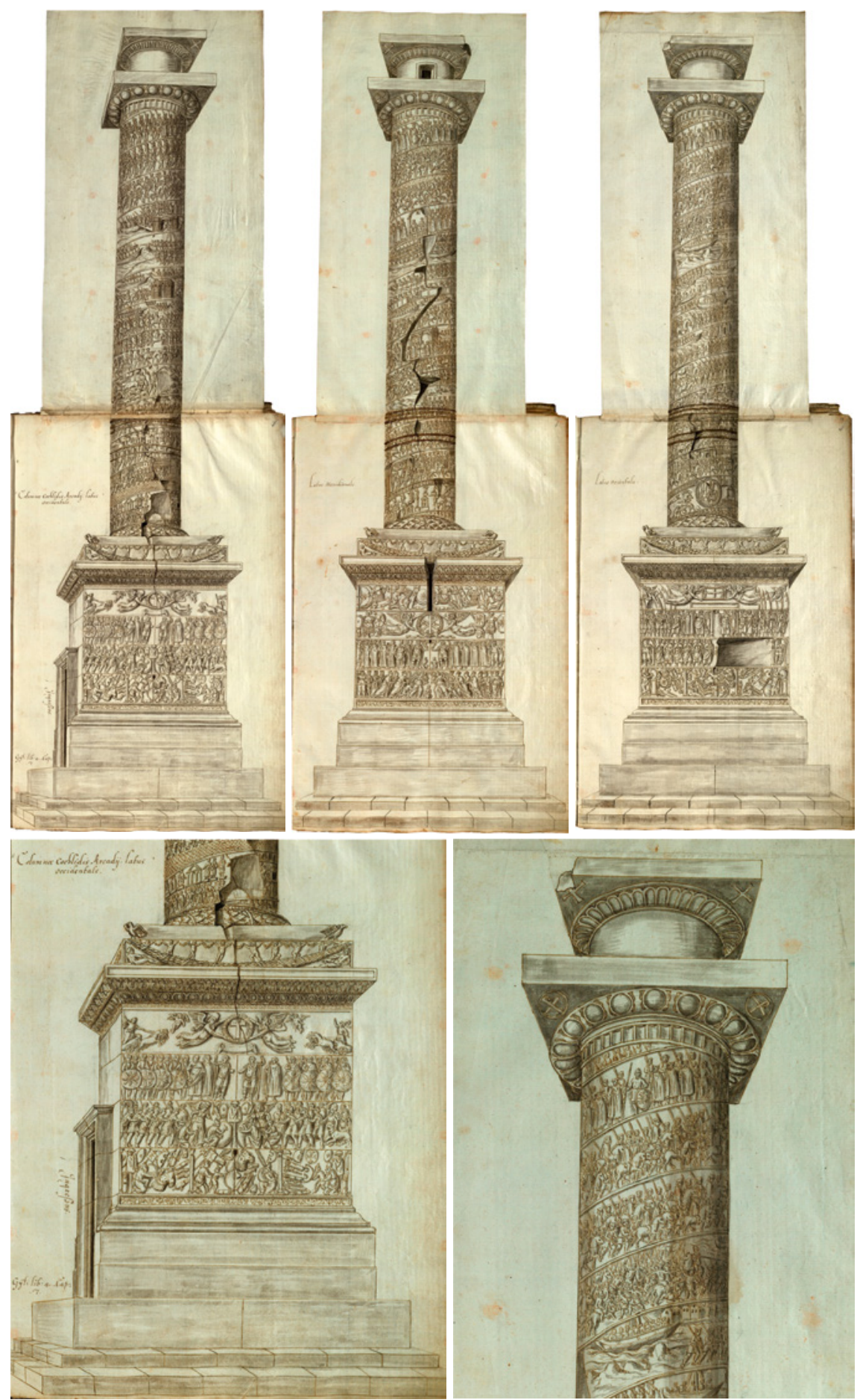

FIGURES 13.93-13.97 Drawings of the Column of Arcadius in Constantinople, 1570s, possibly commissioned or executed by Paolo Strada on behalf of his father; 


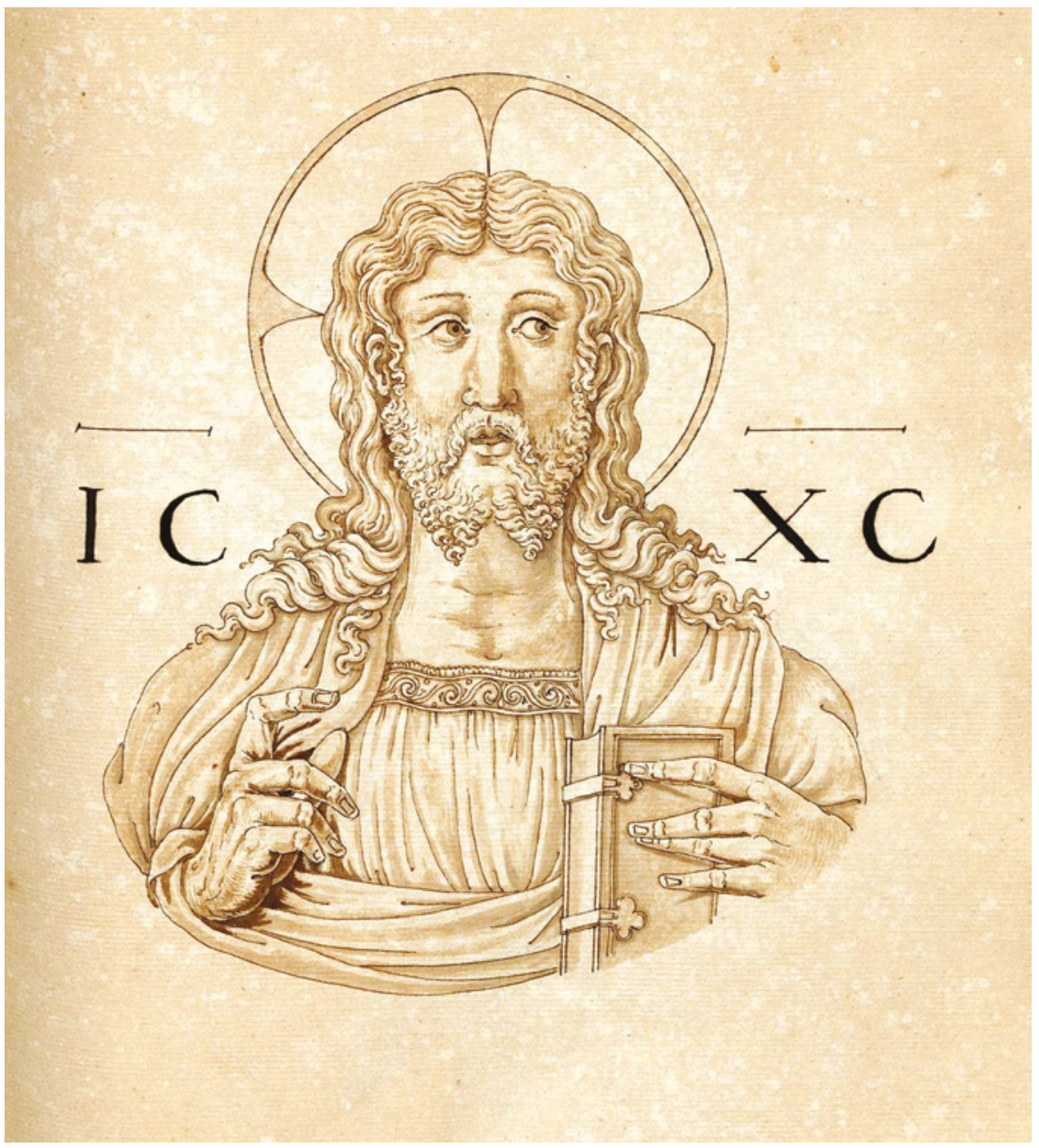

FIGURE 13.98 Workshop of Jacopo Strada, documentary drawing of an unidentified mosaic or mural of Christ Pantocrator, Vienna, Österreichische Nationalbibliothek.

The series of the three rather precise drawings of this monument preserved in the so-called 'Freshfield Album', containing drawings of ancient and modern monuments in Constantinople now in the library of Trinity College, Cambridge, may very well have been executed by Paolo Strada, or under his supervision [Figs. 13.93-13.97].107 The style and precision of the drawings, which

107 Cambridge, Trinity College Library, Ms. 0.17.2; see Freshfield 1922 and Kurt Weitzmann in Age of Spirituality 1977, pp. 79-81, nr. 68. The drawings appear to have been in the possession of David Ungnad von Sonnegg, Imperial Ambassador at the Ottoman court in 1572 (when Paolo was still there) and from 1574-1578. It would have been exactly the type of commission Paolo, who was a draughtsman himself, would have executed. I am very grateful to Richard Tuttle for having drawn my attention to these drawings. 
include views of three sides of the Column of Arcadius in its entirety, is similar in elegance and precision to those Strada commissioned at Mantua from Ippolito Andreasi. The only anomaly is that the draughtsman of the Freshfield album was aware of the true identity of the column of Arcadius, whereas Strada himself apparently was not. ${ }^{108}$

Strada's particular interest in the 'colonna coclida istoriata' is quite evident: a type of monument which combined architecture with figurative sculpture providing a lot of factual archaeological information and an imperial iconography was bound to appeal to an Imperial Antiquary who was also a practising architect. He shared this interest with many of his contemporaries, to begin with his master Giulio Romano, who had not only repeatedly used individual figures and scenes from the frieze of Trajan's column as sources of inspiration, but had actually emulated it in the splendid stucco double frieze, representing the battle-order of Julius Caesar, of the Camera degli Stucchi of the Palazzo del Te. ${ }^{109}$ That Strada included Giulio's drawings of this frieze among the antiquarian material he intended to publish — and on an equal footing with Giulio's antique examples - testifies both to his admiration for Giulio's archaeological erudition and his conviction of the utility of the information such material could provide. Several of the original designs from Giulio's studio are now in the Louvre; the complete set of copies preserved in the Albertina may well be the set Strada prepared or commissioned for the engraver on the basis of the original drawings in his possession. ${ }^{110}$

\subsection{Strada's Commissions of Visual Documentation: Contemporary Architecture and Decoration}

\subsubsection{Rome}

Armenini's description of Strada's activities in Rome appear to stress his interest in classical Antiquity, but in fact he says that Strada acquired material documenting 'cose assai antiche, che si sono ritrovate per quella Città in diversi tempi, che però erano delle più notabili, et più perfette dell'altre', that is: 'quite ancient things found in that City dating from various periods, especially those that were more noteworthy and more perfect than others'. The plans of Florence and Pisa Cathedrals in the Strahov Codex witness that these could

\footnotetext{
108 But it is also possible that Strada consciously preferred to indicate Arcadius' column with the name under which it was perhaps more generally known.

109 Agosti/Farinella 1984, pp. 415-416; on the Camera degli Stucchi, see Verheyen 1977, pp. 123-127; Konrad Oberhuber, 'Lappartamento dei Giganti e l'ala meridionale', in Giulio Romano 1989, pp. 364-374.

110 Index sive catalogus, Appendix D, nr. 14; discussed above, Ch. 13.6.3.
} 
include the 'most perfect' achievements even of the Middle Ages, as does the singular image of a Christ Pantocrator in the Vienna Codex miniatus 21,3 [Figs. 13.22-13.23 and 13.98]. ${ }^{111}$

But as a true follower of Giulio and an admirer of the divine Raphael, Strada chiefly collected material documenting the art of his own time, which heavily drew upon the art of classical Rome. In his I veri precetti della pittura Armenini gives an eloquent description of Raphael's Loggia in the Vatican, which he considered as the archetypal example to be followed by anyone intending to decorate a loggia [Figs. 13.99-13.101]. He then relates how:

...every part of this ensemble, including the floor, was drawn on paper and illuminated, in the most suitable manner, by the hand of the most talented young men that were in Rome in my time, among whom I myself took part; and thus coloured it was then sent by whom had commissioned it, and who paid royally for it, to Antwerp to a great lord of the Fuggers who, it is said, took the greatest delight in it. And that agent whom I mentioned had another copy made, which, soon afterwards, he himself took to Spain to the great Court of King Philip, with other drawings which he bought everywhere or which he commissioned us to draw for him. ${ }^{12}$

The documentation of Raphael's Loggia mentioned here has been preserved in a splendid illuminated codex of the Nationalbibliothek in Vienna, which has been discussed by Bernice Davidson. ${ }^{113}$ The sumptuousness of the codex, illuminated in many colours including lapis lazuli and gold leaf, bears witness to Fugger's high ambitions, its precision to Strada's unbound admiration for this greatest example of Renaissance decoration [Figs. 13.102-13.107]. It is also perhaps the best testimony of Strada's perfectionism, and as such can be compared with the less sumptuous, but equally precise set of drawings of the architecture and decoration of the Palazzo del Te at Mantua that Strada commissioned from the young local painter Ippolito Andreasi in $1567 .{ }^{114}$ Though Armenini's contention that Strada provided a second copy to Philip II is not corroborated by other sources, it is nonetheless clear that the precision and magnificence of such drawings strongly appealed to other collectors besides

\footnotetext{
111 Vienna, ÖNB, Cod. min. 21,3, fol. 29; I have not been able to identify the original—since it is preserved in the context of a set of numismatic drawings, it may be Strada's own interpretation of a medieval or spurious coin, instead of the copy of a mural or mosaic.

112 Armenini 1587, pp. 180.

113 The drawings of the Vatican Loggia are now in öNB, Cod. min. 33; see Davidson 1979; Davidson 1983; Davidson 1984; Jansen 1987, p.15.

114 Dïsseldorf, Kunstbibliothek; catalogued and discussed in Harprath 1984 (with further bibliography).
} 

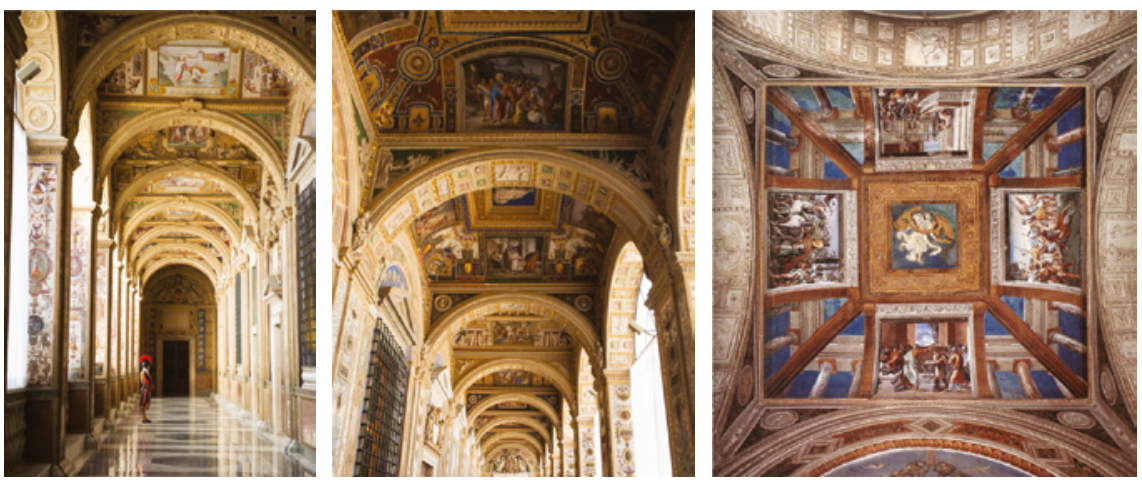

FIGURES 13.99-13.101 Raphael and workshop: the Loggia in the Vatican Palace.

Fugger. Already in 1548, for example, Granvelle, the learned Bishop of Arras, had acquired similar sets of drawings documenting the Sistine Chapel ceiling and the Sala dei Giganti in the Palazzo del Te, which were executed by the Mantuan engraver Giovanni Battista Scultori. ${ }^{115}$

Whoever had been the patron of the Vienna version, it is obvious that either Strada retained access to it, or-more likely — that he had made a second copy for himself, though that may have been less expensively illuminated. He could use such a copy as the model for the engravings of an ambitious publication on the sights of Rome, of which the Loggia was to be the principal component. ${ }^{116}$ From this same description it results that he also owned a set of comparable drawings of Raphael's Vatican Stanze, most likely a version of the same set Giovanni Battista Scultori had made for Granvelle: from a later source we know that Scultori was among the artists employed by Strada in his projects. $^{117}$

In conjunction with Armenini's description of Strada's activities in Rome this suggests that he commissioned similar documentation of other contemporary projects. Certainly such drawings were made of other objects: a good example is a beautifully detailed measured drawing in the Albertina documenting the decoration of the entire facade of the Palazzo Gaddi, decorated with Polidoro da Caravaggio's celebrated friezes all'antica, painted in grisaille [Fig. 13.108]. ${ }^{118}$ This drawing is very close to the Loggia drawings: note for

\footnotetext{
115 Greppi 1977, p. 434.

116 Index sive catalogus, Appendix D, nr. 43.

117 Strada himself refers to his having at one time employed Scultori in a letter to the Duke of Mantua (Doc. 1577-10-04).

118 Vienna, Albertina, inv. nr. 15462.
} 


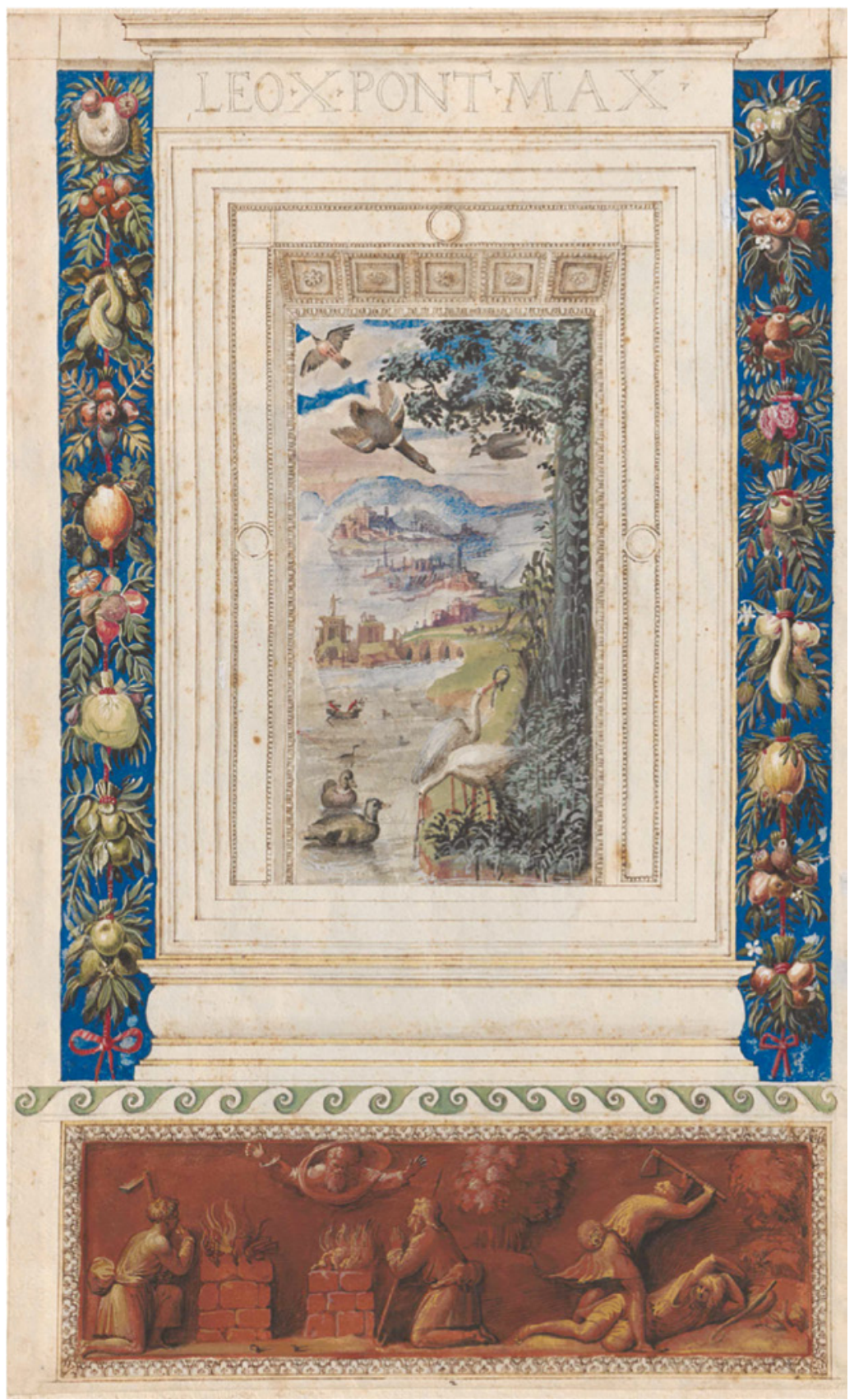

FIGURES 13.102-13.106 Giovanni Battista Armenini and others, some of the set of illuminated drawings documenting the entire Vatican Loggia, commissioned by Jacopo Strada from Giovanni Battista Armenini and others; Vienna, Österreichische Nationalbibliothek. 


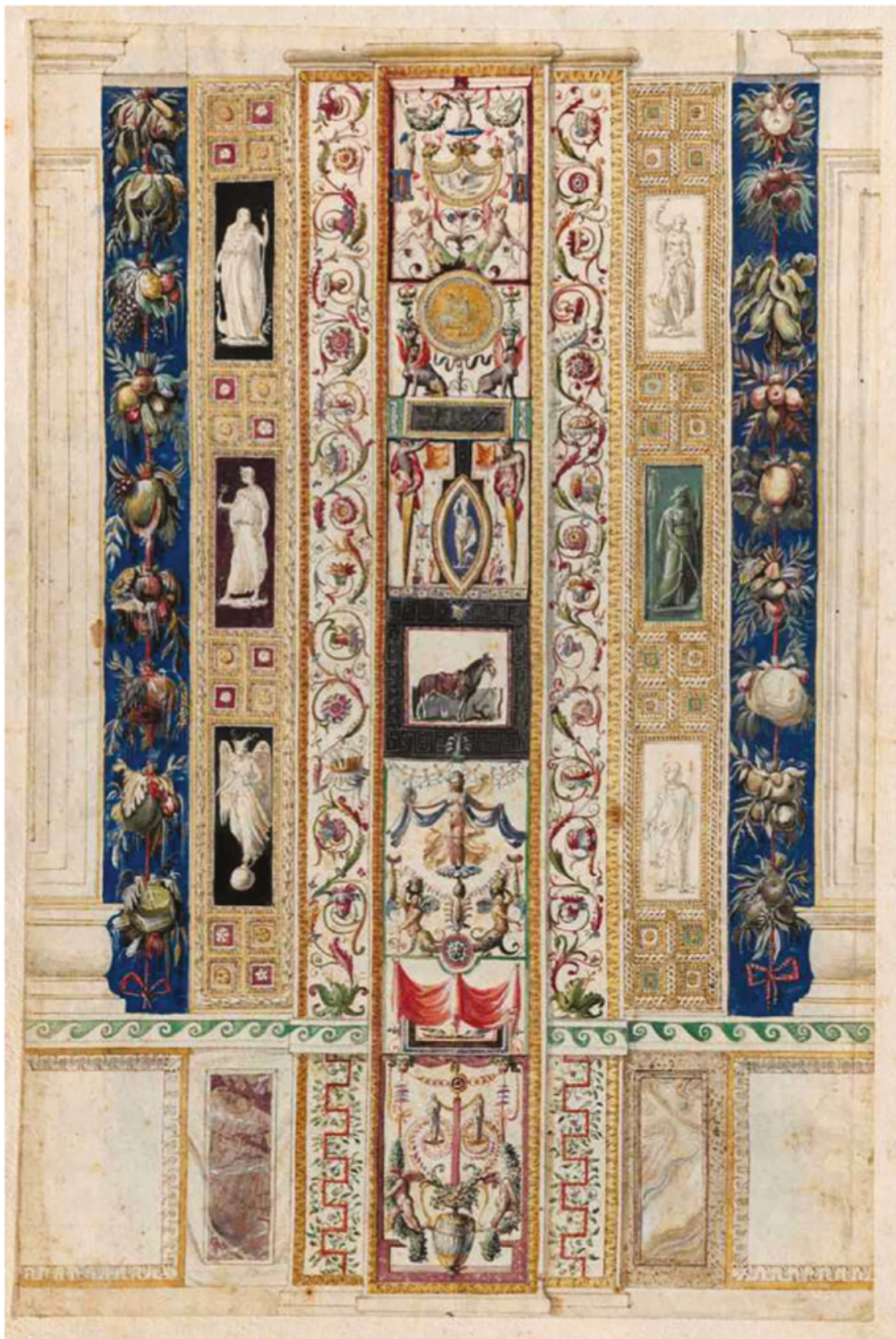



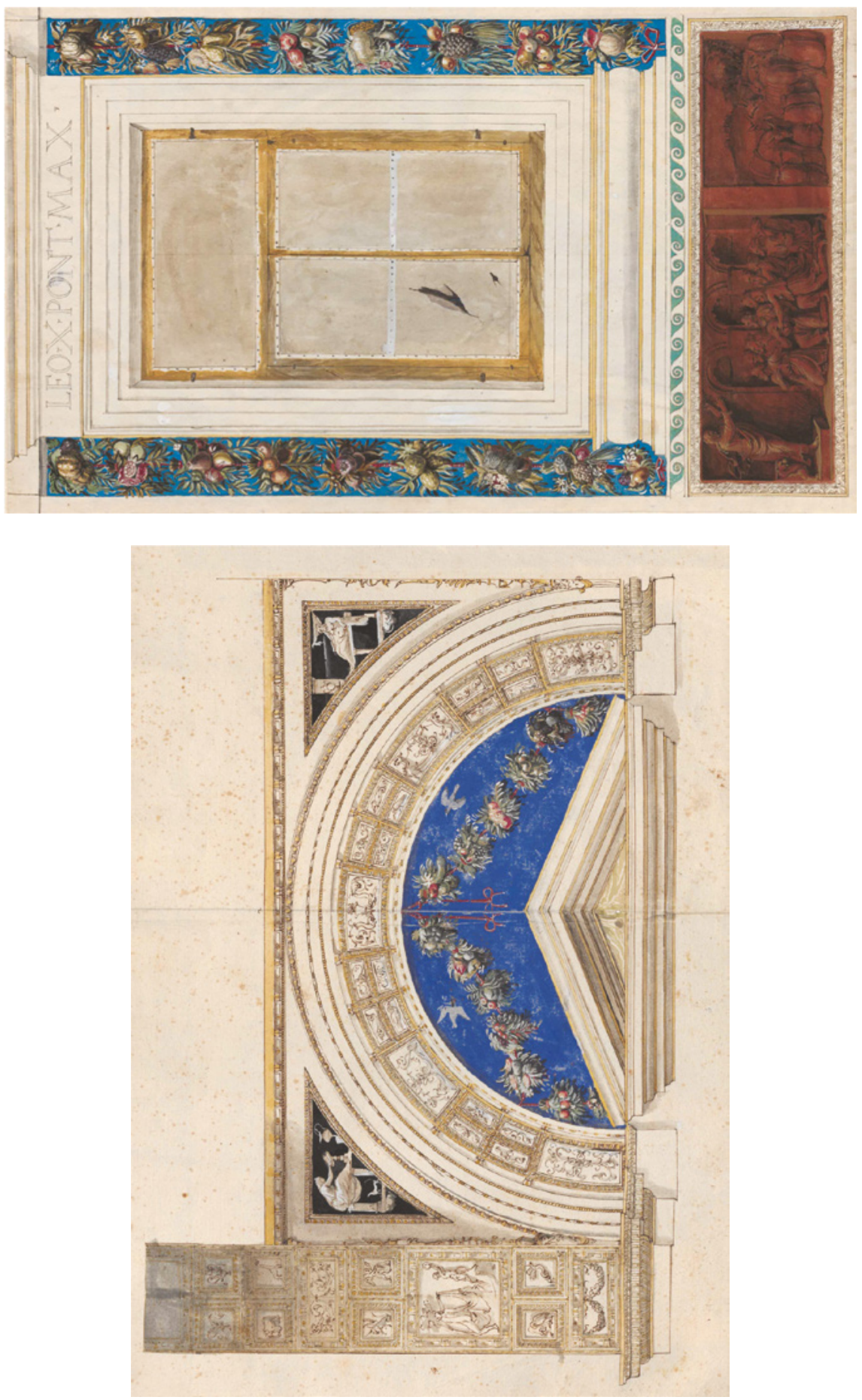


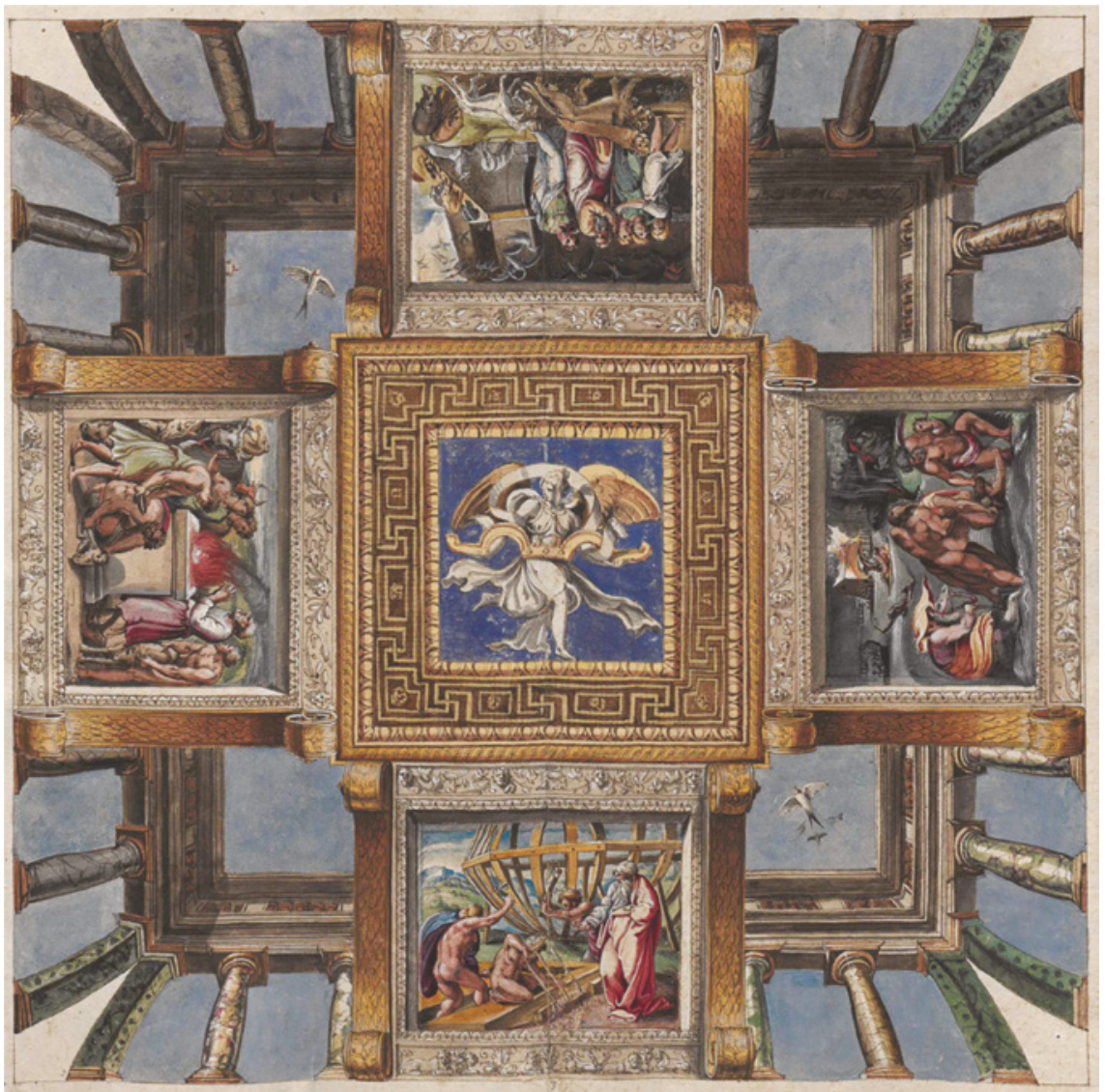

instance the tear in the waxed paper filling the window frames of the Palazzo Gaddi, which is also found on fol. $5^{0}$ of the Loggia volume [Fig. 13.104]. That the paper filling the windows is shown at all in both drawings in itself may be an indication of their mutual relation, and I strongly suspect that the Albertina drawing is one of the results of Strada's commission.

But unfortunately we do not have any further indication of what other monuments Strada may have had documented. Certainly he would have been interested in the patriarchal basilicas, including Old St. Peter's, as well as in the works of Bramante, Michelangelo and Raphael, such as New St. Peter's, the Belvedere, Palazzo Farnese, the Capitol, Villa Madama, the palaces designed by Raphael, Sangallo, Peruzzi and Giulio Romano and so on. He will have been equally eager to acquire documentation on the projects that had more recently been completed, such as the Orti Farnesiani, or were under construction while 


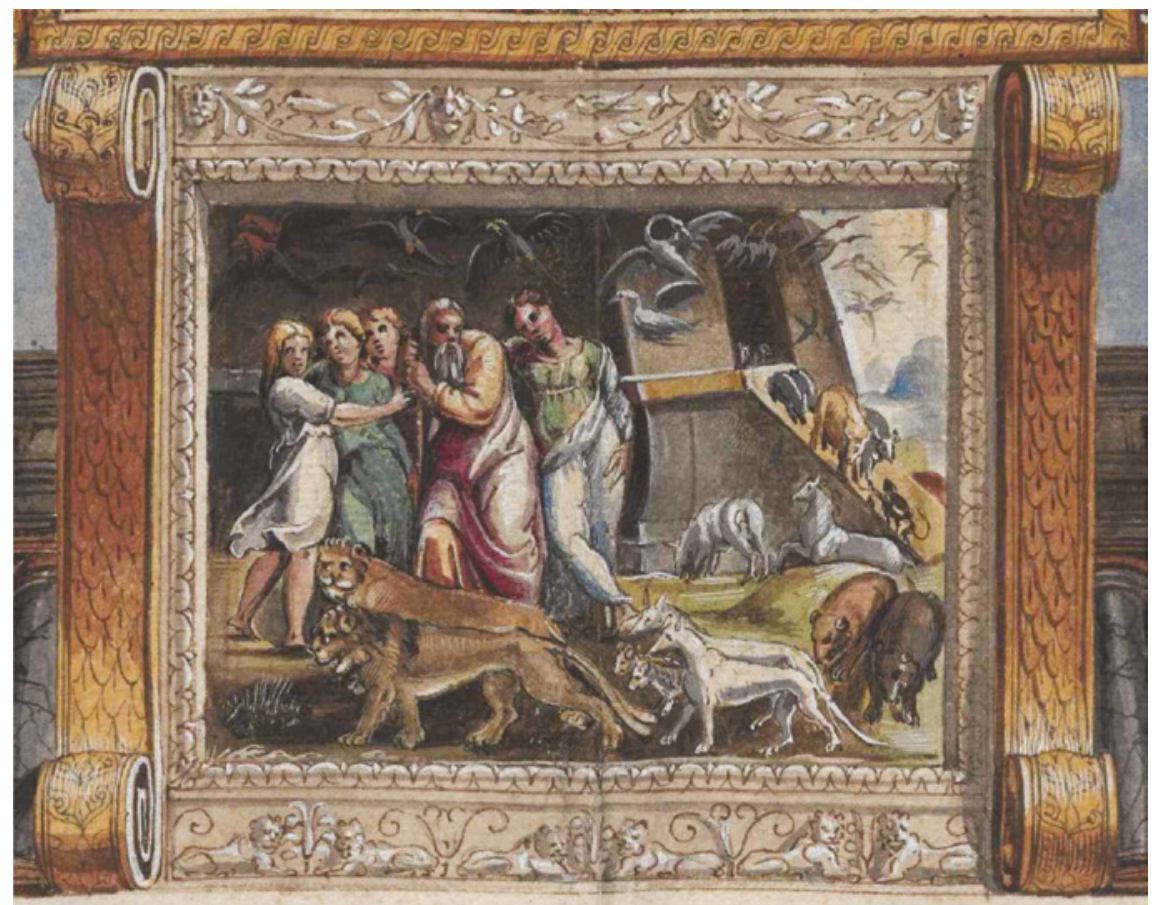

FIGURE 13.107 Giovanni Battista Armenini (?), naar Raphael, The Animals leave the Ark of Noah, detail of Fig. 13.106.

he was in Rome, in particular the Villa Giulia, of importance also as an exemplary Antikengarten. Perhaps he also had access to the plans at the time being developed for the Villas of Cardinal Alessandro Farnese at Caprarola, by Vignola, and of Cardinal Ippolito d'Este at Tivoli, by Pirro Ligorio.

Apart from architectural designs Strada must have been eager to acquire documentation of the most important decorative schemes in Rome, in addition to that of the Vatican Loggia and Stanze. Some of this he may have found among the material included in his purchases from the heirs of Perino del Vaga and Giulio Romano: as we have seen Strada claimed to possess some of Raphael's autograph designs for the Stanze. It is likely that in addition he also obtained a series of drawings of the Sistine Chapel, similar to those Giovan Battista Scultori had made for Cardinal Granvelle. Among Perino's drawings he would have found sufficient material to document the decoration of Paul III's appartment at the Castel Sant'Angelo: as we have seen, copies of drawings of the sopraporte of the Sala Paolina are in fact preserved among Strada's material in Vienna [above, Fig. 13.63]. 


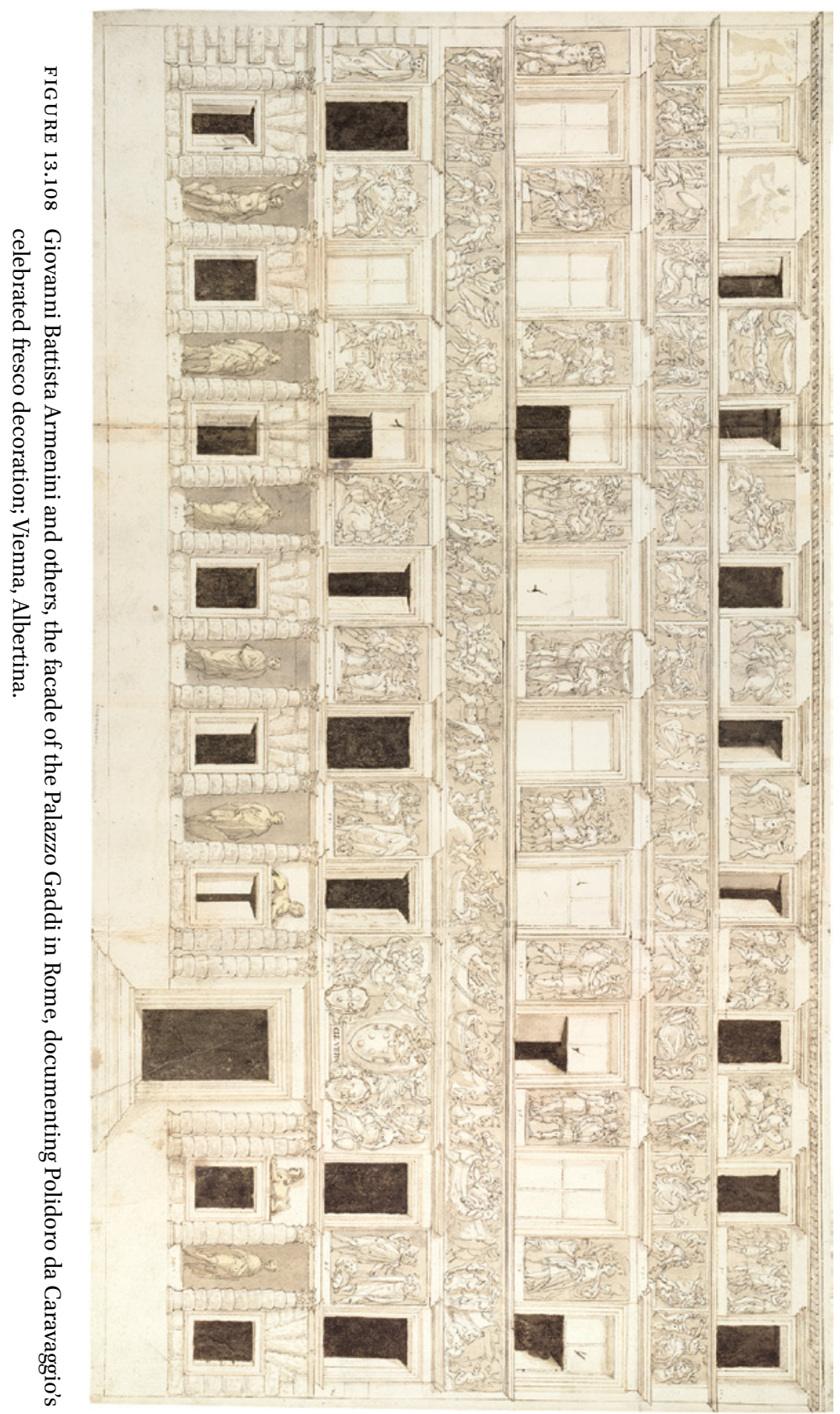




\subsubsection{Mantua}

Armenini's description suggests that Strada's acquisitions in Rome in the mid1550 s were part of an ambitious and carefully considered project to document the best examples of both ancient and contemporary art in Rome. That this was indeed Strada's intention is corroborated by his similar activities in the 1560 s and in the 1570s, which are somewhat better documented. In the summer of 1567 , when he visited Mantua from Venice, he commissioned the young but gifted draughtsman Ippolito Andreasi to execute extremely detailed documentation of the Palazzo del Te and of the apartments in the Palazzo Ducale Giulio Romano had designed for Duke Federico.

This project is well documented because Niccolò Stopio expressly wrote to Mantua for information on his rival's activities, which he then reported to their common patron, Hans Jakob Fugger. ${ }^{119}$ Duke Albrecht V of Bavaria paid for (a set of) the drawings of the Palazzo del Te, but it can be assumed that Strada, as in the case of the drawings after Raphael's Loggia and after the friezes of Trajan's and Theodosius' columns, kept a copy for himself: the copy which he would use to produce the prints of a planned detailed illustrated publication of the Palazzo del Te. This can be considered as a companion volume to the planned publication of the Loggia, which it precedes in the Index sive catalogus:

A book in which is depicted the most beautiful and famous palace in the whole world (in the Italian language called Palazzo del Te). This is situated at a bowshot's distance from Mantua, and is perfectly built according to the precepts and laws of architecture and decorated with most beautiful and pleasant pictures. I had this palace drawn at my expense: first the measured drawings of its foundations, both inside and out, were made, then the gardens and parks with the habitations in them. Then the measured drawings of all the chambers, with all their annexes, [sculpted] figures and paintings: all and every one of which have been executed with exquisite study and care. And from this it was possible to put together a book which could be enriched in the appropriate places with a description, and thus the book was both written and drawn.' ${ }^{20}$

In this case we know more about Strada's intended publication, because its essential components have all been preserved: these include a detailed ground plan provided with Strada's annotations [Figs. 13.110-13.111], a set of about forty very detailed elevation drawings of the facades [Fig. 13.109] and of the

\footnotetext{
119 Above, Ch. 12.5.2

120 Index sive catalogus, Appendix D, nr. 42.
} 


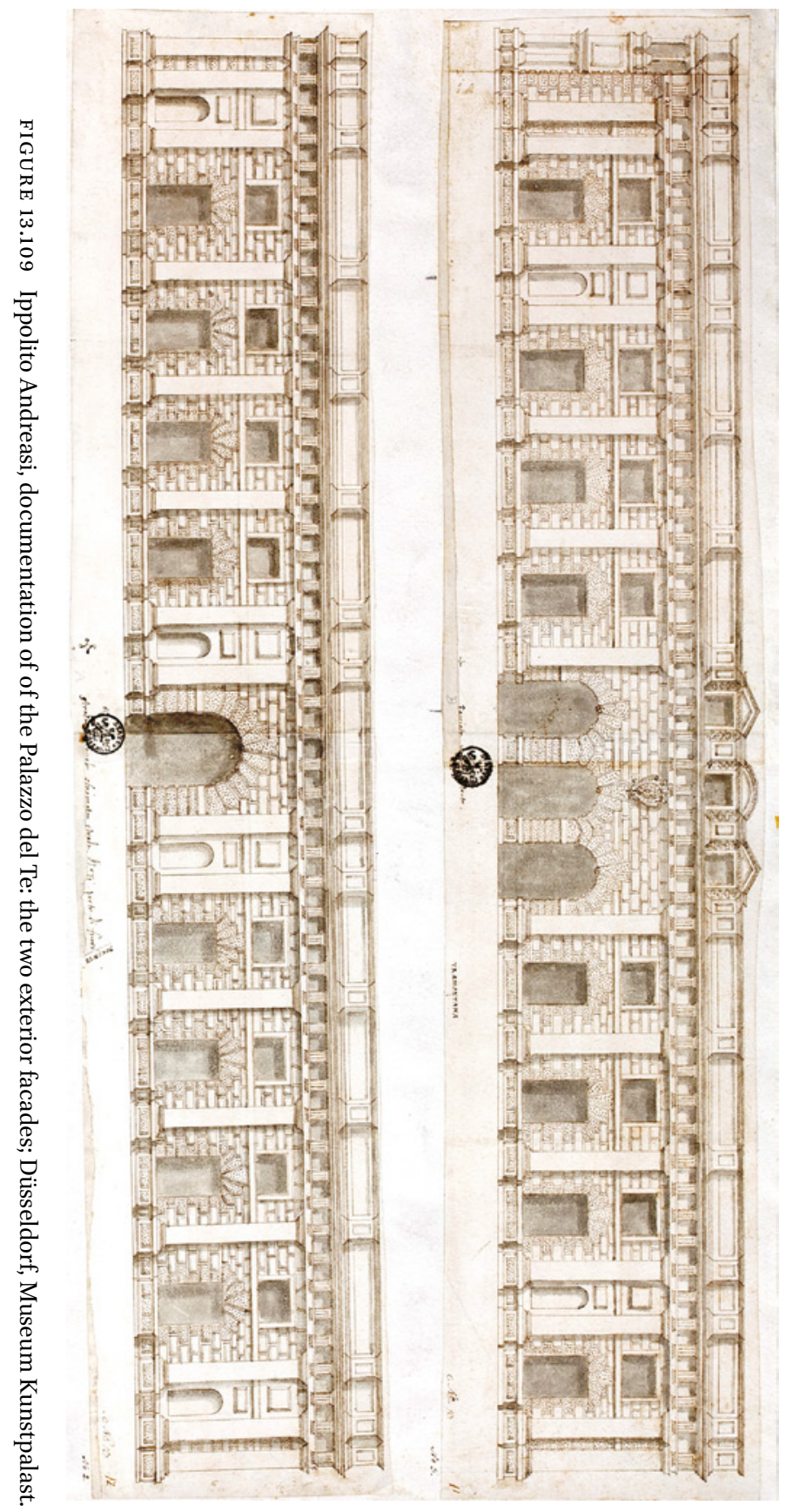


inner walls and ceilings of each separate chamber, documenting every detail of the painted and stucco decoration [Figs. 13.112-13.113], and finally Strada's own room-by-room description of the palace, making the Palazzo de Te probably the best documented Renaissance building in existence. ${ }^{121}$ Strada's enthusiasm for this building - 'the most beautiful and resplendent palace in the world' - was based on a complex amalgam of juvenile memories - he had seen it being built and decorated, and may himself have contributed-coupled to a taste schooled on the premises of the style of Raphael and his pupils, in particular Giulio, and to Strada's patriot pride as a Mantuan citizen and Gonzaga vassal, as he styled himself. ${ }^{122}$

In any case Strada was very closely involved in the production of the material, which he could not have realized without the tacit or explicit support of Duke Guglielmo, and the help of his Prefetto dell fabbriche, Strada's exact contemporary and old friend Giovanni Battista Bertani, who probably made available some of the original drawings and designs kept in the Gonzaga office of works. That these drawings were at the basis of the documentation rather than the finished building is evident from the anomalies between Andreasi's drawings and the building as executed, and from Strada's annotations and his descriptions. Yet drawings and executed building were carefully confronted, as is evident from Strada's annotations and from the report that he had men at work both 'in Castello' - the Palazzo Ducale — and in the Palazzo del Te, at the other end of town. Running around to supervise their work had even caused him an attack of the gout. ${ }^{123}$

In this project he was well served by Bertani, whose help he gratefully acknowledged in a much later letter to Duke Guglielmo Gonzaga. From this

121 The drawings in Düsseldorf, Kunstmuseum (ca 40 sheets documenting the Palazzo del Te, ca 35 sheets documenting some interiors in the Palazzo Ducale); the plan of the Palazzo del Te, ibid., Fp 10937; the description: Jacopo Strada, Ordine come vanno li dissegni del Palazzo del Ti fuori di Mantua, ms. Vienna, öNB-Hs, Cod. 9039, ff. 154-155. The drawings are catalogued in Harprath 1984, and discussed in Giulio Romano 1989, pp. 333-334 and passim; and in Belluzzi 1998, Saggi, pp. $3^{1-36}$ and passim; Strada's description printed in Davari 1889; Verheyen 1967, pp. 68-69. The plan and perhaps the outlines of the elevations may have been prepared by Bertani, whose help in Strada's project was gratefully acknowledged in a later letter of Strada to Duke Guglielmo.

122 In his letters to Duke Guglielmo, and only to him, Strada habitually referred to himself as his 'vasallo', f. i.: 'E questo favore lo serbaro a miglior tempo a commodità di Vostra Excellenza Illustrissima, perchè dal canto mio, essendogli Suo vasallo, non posso dessiderar se non cosa che li agradi e torni a utile; suplicandoLa si degni a comandarmi e servirsi di me dove vaglio e posso'. (Doc. 1568-10-11; other examples: Docs. 1568-12-28; 1571-11-20; 1577-10-04).

123 Von Busch 1973, pp. 204-205 and pp. 340-3421, notes 84-92. 

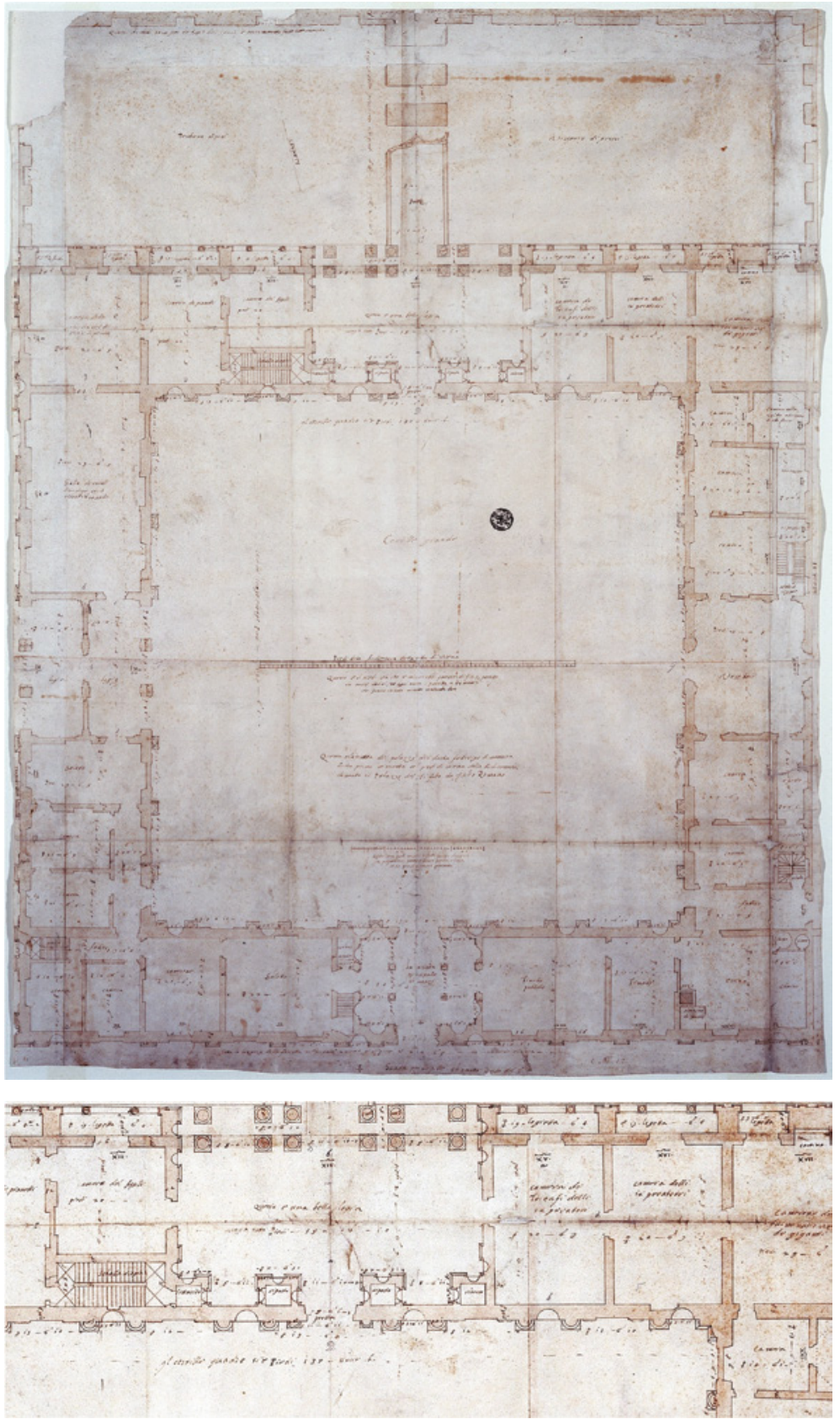

FIGURES 13.110-13.111 Ippolito Andreasi (?) and Jacopo Strada, after Giulio Romano, plan of the Palazzo del Te, Mantua, and detail: the garden wing with the Loggia di Davide and adjacent chambers; Düsseldorf, Museum Kunstpalast. 


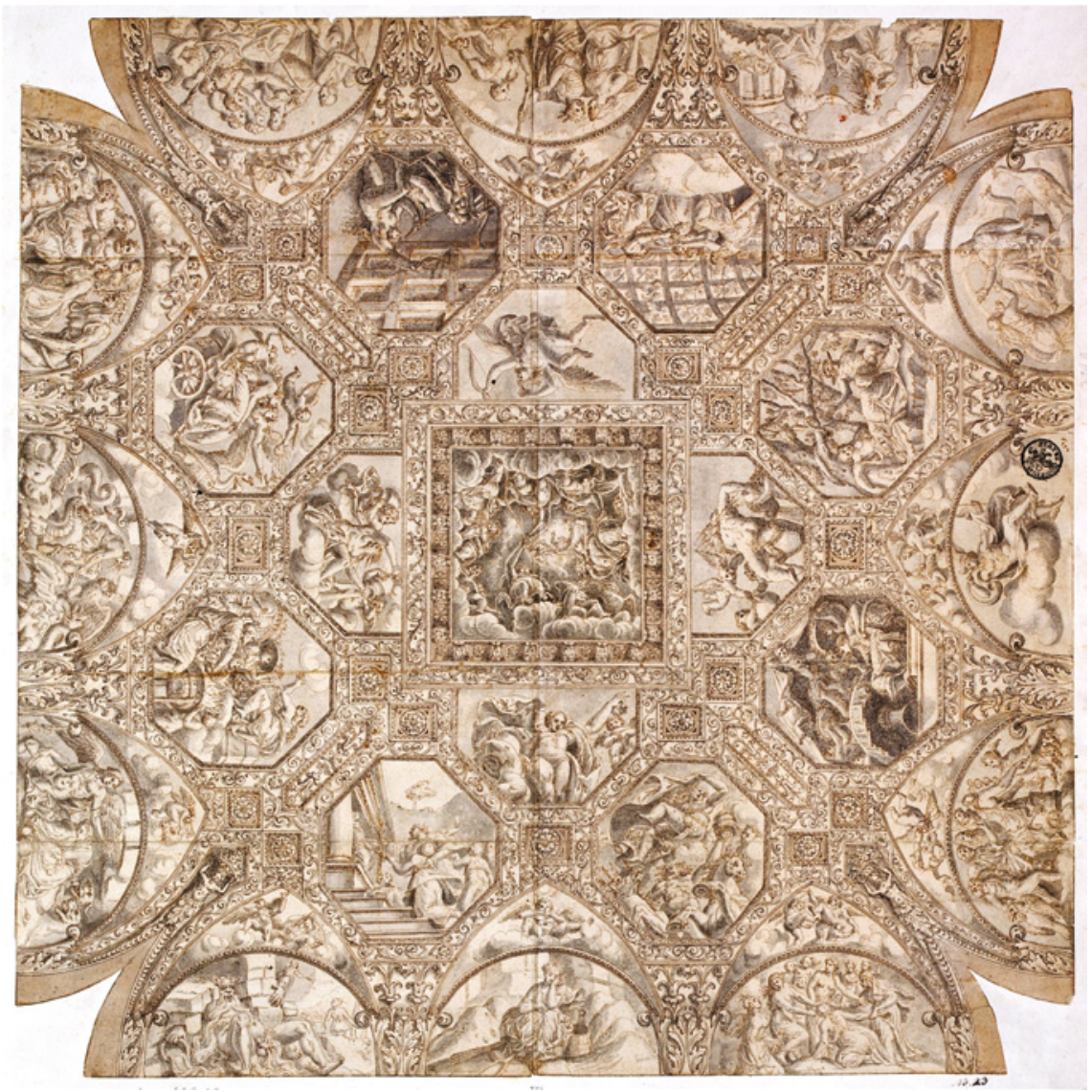

FIGURES 13.112-13.113 Ippolito Andreasi, documentation of the Palazzo del Te, Mantova: the Camera di Psiche, ceiling; and the Camera degli Stucchi, end wall; Düsseldorf, Museum Kunstpalast.

it results that in his time Bertani had provided Strada with plans and elevations of Duke Guglielmo's principal commission, the Palatine Basilica of Santa Barbara, which Bertani had designed himself, the architecture of which Strada considered 'the most beautiful in its type he had seen anywhere in Italy'. In addition Bertani had provided him with the plans and elevations of the two Alberti churches in Mantua, Sant'Andrea and San Sebastiano, and of Mantua Cathedral (doubtless as modernized by Giulio Romano in 1545). Strada's formulation suggests that Bertani had also been responsible for the measured drawings of the Palazzo del Te which served as the basis for Andreasi's drawings of its decoration. The Mantuan engraver Giovanni Battista Scultori also had been of assistance to Strada. Doubtless Strada had applied to Bertani and 


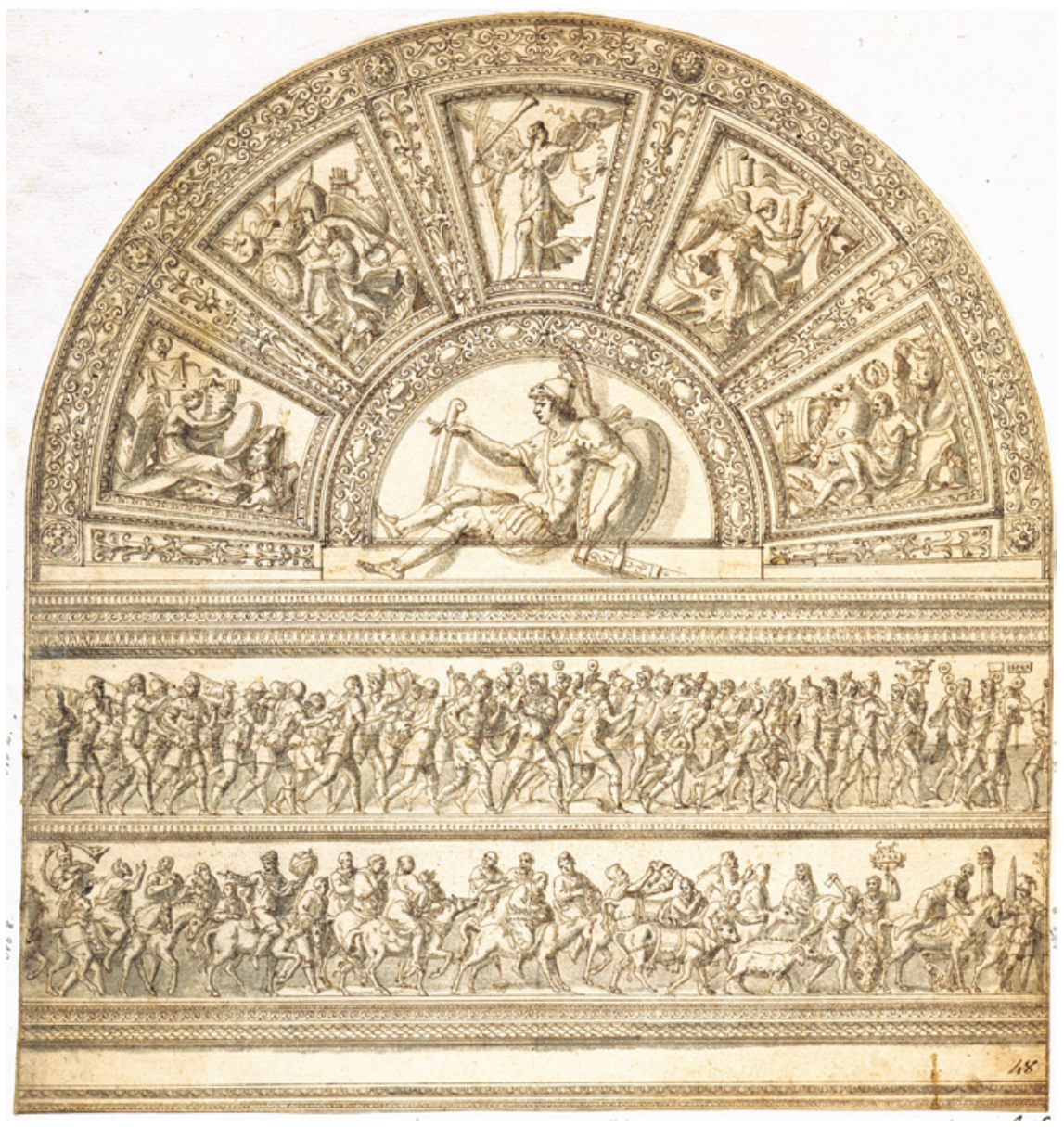

Scultori to find a draughtsman to execute his commissions: the performance of the draughtsman he found, Ippolito Andreasi, was so satisfactory that a decade later Strada again wished to employ him in a similar project. ${ }^{124}$ The number of artists involved - as we have seen, at the same time Strada also employed the local painter Giorgio Molinarolo to execute copies of several paintings in Mantua collections-indicates the scale of Strada's operations at the time.

Not all the commissions mentioned in this letter need to have been executed during Strada's short stay in Mantua in the summer of 1567 , which was

124 Doc. 1574-10-04(a). Strada's praise of Santa Barbara doubtless was also intended to flatter its patron, Duke Guglielmo Gonzaga of Mantua, to whom the letter was addressed. 


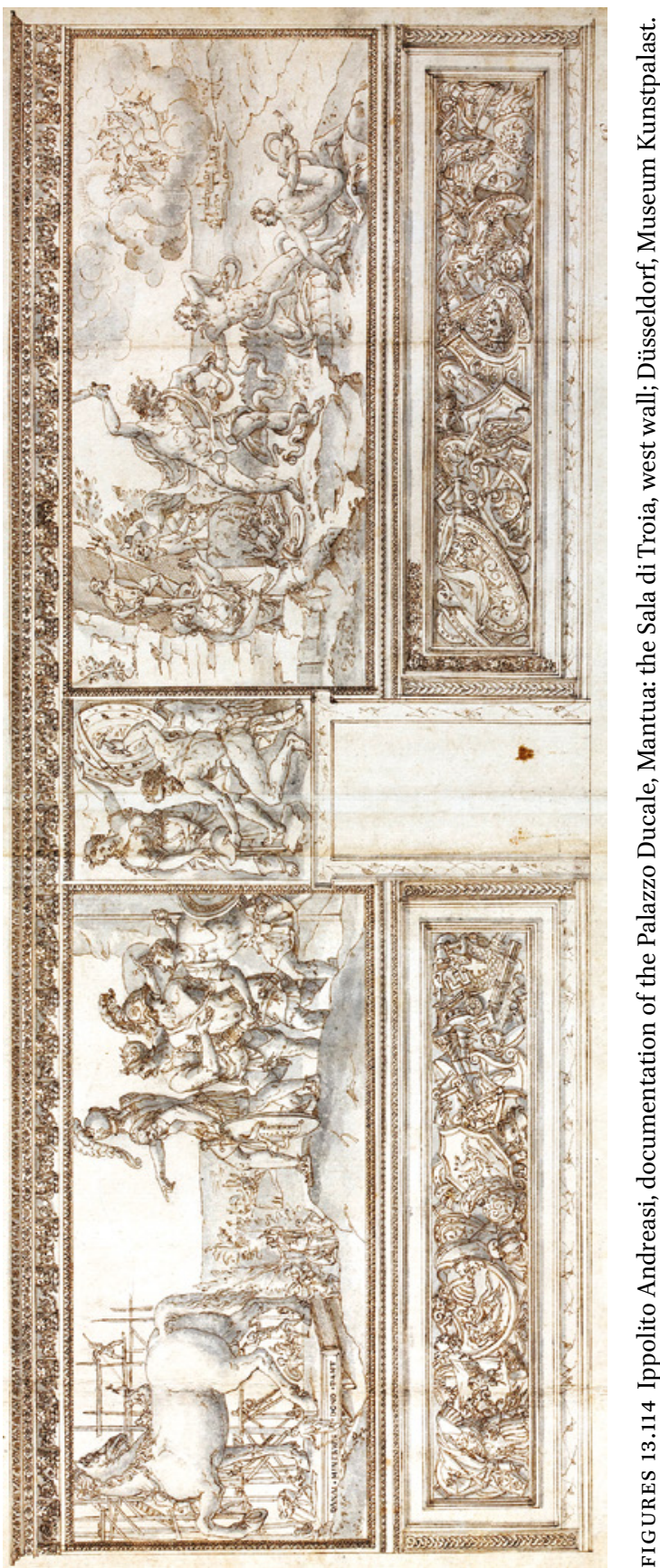

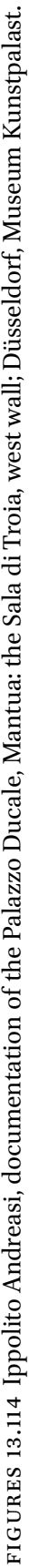



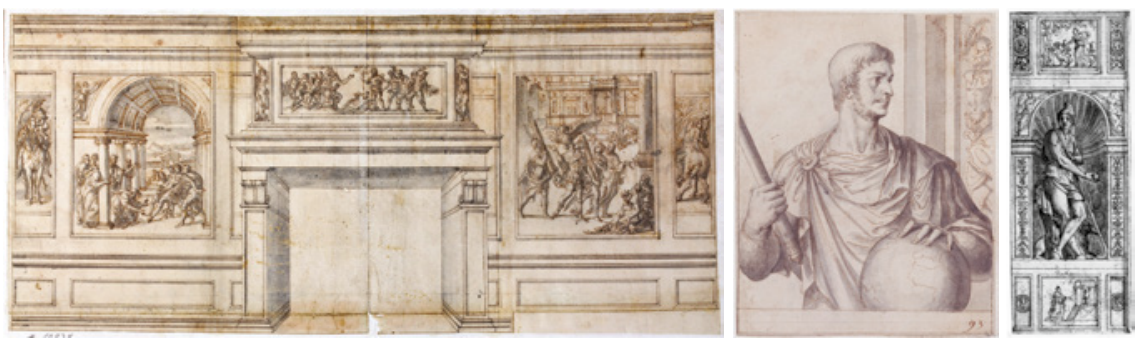

FIGURES 13.115-13.117 Ippolito Andreasi, documentation of the Palazzo Ducale, Mantua: various elements of the Camerino dei Cesari; Düsseldorf, Museum Kunstpalast.

interrupted by his precipitate flight from the Inquisition. Once he had found colleagues he could trust, such as Bertani and Andreasi, his personal presence was not necessary, and commissions could be transmitted by correspondence or the mediation of travellers between Mantua and Vienna. But when a decade later Strada again took up his collecting of documentation, both Scultori and Bertani had died and he had lost contact with Andreasi, which is the reason why he wrote directly to Duke Guglielmo, asking him to help him arrange the commission of the desired material: in the first place similarly detailed drawings of the architecture and decorations of the Ducal palace at Mantua and of the important Gonzaga residence at Marmirolo, likewise designed by Giulio Romano and his pupils. It seems hardly credible, but it appears that the Duke indeed took the trouble to help Strada have his commissions executed, because Andreasi's drawings of several rooms in the Palazzo Ducale have been preserved intact together with his earlier drawings of the Palazzo del Te [Figs. 13.114-13.117].

\subsubsection{Illustrations for Leandro Alberti's Description of Italy}

The letter cited here, dated 4 October 1577, gives some additional information on what type of material Strada had collected, and also mentions an explicit purpose: the publication of a very amply enriched, profusely illustrated edition of La Descrittione di tutta Italia by the Dominican historian Leandro Alberti. ${ }^{125}$ This popular first complete survey of the historical geography of Italy had first

125 Doc. 1577-10-04(a). On the same date Strada wrote a similar request to Duke Alfonso II of Ferrara, and another letter to Grand Duke Francesco of Tuscany, asking him to arrange for the book to be printed in Florence, cf. Docs. 1577-10-04(b), (c) and (d). His project is also described in the Index sive catalogus (Appendix D), $\mathrm{nr}$. 44, and in his letter to Christophe Plantin Doc. 1578-08-13). 

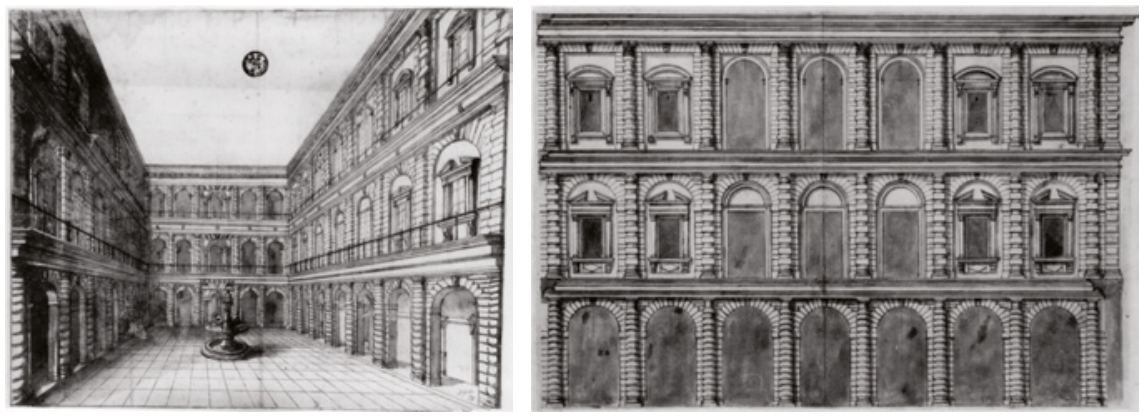

FIGURES 13.118-13.119 Anonymous draftsman, working for Jacopo Strada: perspective view and elevation of Ammannati's cortile of the Palazzo Pitti, Florence.

been published in 1550, had been reprinted many times in expanded versions, and for the first time in Latin in 1567; it continued to be regularly reprinted for another century. ${ }^{126}$ So Strada's initiative to bring out another edition is not original as such. What distinguished him from other editors of the book is his ambition to hugely increase the amount of information it contained. To the descriptions of each single region and city he planned to add records of its learned men, accompanied with a list of their published and unpublished works. Moreover he intended to include careful transcriptions of ancient epigraphs present, 'portrayed exactly as they are in those marbles, with the figures and other ornaments surrounding them', and illustrations of the coats of arms of its princes and its principal noble families. And these were by no means the only images he planned to add: he also wished to include geographical maps of each region, and detailed profiles of each single town. For this reason he begged the Duke

...to have documented for me in drawing Your Highness' cities, that is Mantua, Casale, Aich, Alba and the others Your Highness has in the Monferrato; and also Your Highness' principal fortresses: in the Mantovano Your Highness has fortresses that seem cities, such as Viadana, Cannedo, Gazolo and others I don't remember: those I would like to have as well, but that the view should be taken from a point where they show well, and that it should be drawn on a sheet of folio reale size, or slightly smaller... ${ }^{127}$

126 On the book, its author and its sources, see now Petrella 2004.

127 Doc 1577-10-04(a). 
Finally he intended to include carefully drawn documentation of its ancient monuments and its principal modern buildings, 'with well-measured plans and elevations and the measurements written in the appropriate places', assuring the Duke that it was his intention 'not to leave out anything that is remarkable in my fatherland $<\ldots . .>$ and particularly [its] buildings.' ${ }^{128}$ It is clear that Strada intended to drawn upon the documentation he had already collected to provide the bulk of the illustrations; but his new project now stimulated him to fill lacunae and to update his holdings.

Nevertheless it is unlikely that Strada would have included Andreasi's documentation of the Palazzo del Te and the Palazzo Ducale in its entirety in his illustrated edition of Alberti's Descrittione. When he described the extraordinary sets of drawings of Raphael's Loggia and Giulio's Palazzo del Te in his Index sive catalogus it is clear that Strada esteemed these exceptional complexes so highly that he wished to publish them integrally in separate illustrated monographs or print-series. His 1575 edition of Serlio's Settimo Libro gives a good impression of the level of precision and the graphic quality of the illustrations he envisaged.

For the Descrittione, on the other hand, he would have contented himself with one or two general views of these monuments. With Andreasi's drawings in Düsseldorf two drawings are preserved which seem more representative for the material Strada had collected documenting Italian architecture of his own time, and which are more plausible examples of the type of image Strada would have included in the Descrittione. They are a perspective view and an elevation of one of the facades of the courtyard of the Palazzo Pitti in Florence, built in 1560 for Cosimo I's consort, Eleonora di Toledo, after designs by Bartolommeo Ammanati [Fig. 13.118-13.119]. These drawings appear very suitable for the illustrated topographical survey Strada had in mind: in his more ample description of the work in his Index sive catalogus he explains that a large part of the woodcut illustrations - all reduced to a uniform size and format similar to the illustrations in his 1575 edition of Caesar's Commentaries - had already been executed, or at least drawn unto the woodblocks ready for the engraver. The importance Strada attached to the Descrittione is clear from the fact that among the many works in his publishing programme it was this that he described first and in greatest detail in his letter to Christoph Plantin, whom he hoped would consider printing it. ${ }^{129}$

128 Ibidem.

129 Doc. 1578-08-13, pp. 3-5. Plantin was interested, but was not sanguine as to its financial feasibility, and certainly was not ready to undertake the project on Strada's conditions; see below, Ch. 14.8. 
Strada appears to have collected similar material from other cities, since the Index sive catalogus also mentions a 'book of the most beautiful and famous palaces that can be seen in Rome and in other Italian cities such as Florence, Mantua and Venice'130 The plans of an unidentified palace and of Pisa Cathedral, and the Duomo and San Lorenzo in Florence preserved in the Strahov codex are probably remnants of this material, and would have served Strada's stated purpose to perfection [Figs. 13.21-13.24].

\subsection{Images as a Source of Knowledge}

As in other aspects of Strada's affairs, the scarcity of surviving sources documenting Strada's collection of drawings and prints allows few definitive conclusions as to its precise scope, size and quality. The preceding account nevertheless demonstrates Strada's vast ambition in this field. The documents we have chiefly relate to Strada's purchases in the 1550 s from Serlio and the heirs of Perino del Vaga and Giulio Romano and his commissions of documentary drawings of the mid-1550s in Rome, in Mantua in the late 1560 s and in Mantua and perhaps Ferrara in the 1570s. Doubtless it is no coincidence that it were these spectacular acquisitions which left some traces in the sources, and there is a good chance that they constituted the most spectacular components of Strada's graphic collection. Yet it is also clear that they must be considered as the tip of the iceberg, and that they represent only a small part of Strada's holdings.

Strada's documented acquisitions formed part of a conscious and focused programme to collect visual documentation. This programme was already under way in the late 1540 s, when Strada had begun collecting the numismatic material he used for the manuscripts he presented to Hans Jakob Fugger and to Ferdinand I and Maximilian II, for his own Epitome Thesauri Antiquitatum of ${ }_{1553}$, and to help out Guillaume du Choul with the illustrations of his Discours de la religion des anciens Romains printed at Lyon in 1556 [above, Figs. 3.55-3.57]. It was a sustained programme, continuing at least until the late $1570 \mathrm{os}$, and there can be no doubt that he was constantly alert to opportunities to enrich his holdings.

It is likely that Strada's preoccupation had originated in his early experience in Giulio Romano's studio. It was common practice for young artists to collect drawings or to copy them, in order to lay in a stock of suitable motifs and compositional 'inventions' for later reference: the practice is described in

$130 \quad$ Index sive catalogus, Appendix D, nr. 35 . 
Armenini's treatise. But Giulio himself had collected drawings and architectural designs on a much grander scale, in particular materials documenting the vestiges of classical art and architecture, which were particularly admired by Vasari. ${ }^{131}$ It was this example that stimulated Strada to collect material on a larger scale than was habitual for young artists and which, coupled to his own antiquarian interest, led him to include material that had no immediate artistic interest, but was a bearer of historical or philological information, such as inscriptions.

\subsubsection{Fugger, Quiccheberg and the Kunstkammer}

Thanks to his subsequent contacts with Hans Jakob Fugger, who was more interested in scholarship and science than in exclusively artistic matters and who, in his huge library, attempted to build up a comprehensive survey of all available learning, Strada became aware of the value of the visual material as a source of knowledge, an alternative or complement to the available textual sources. In his turn Strada influenced Fugger's interest in the careful graphic documentation of objects that were of historic, dynastic or artistic interest, as evinced in the Gehaim Eernbuch - the genealogy of his own family-and in the Ehrenspiegel des Hauses Österreichs - a history of Austria celebrating the Habsburg dynasty - which were both written under his supervision by the Augsburg 'Stadtschreiber' Clemens Jäger. ${ }^{132}$ A case can be made that the stress on visual documentation in Samuel Quiccheberg's museological treatise, Inscriptionis vel tituli Theatri amplissimi of 1565 , is the immediate consequence of Fugger and Strada's fruitful exchange of ideas: the treatise was written more or less under Fugger's supervision, and it refers repeatedly to Strada's works, in particular his corpus of numismatic drawings commissioned by Fugger. ${ }^{133}$ Quiccheberg underlines the value of a well-ordered collection of images:

With time assiduous patrons augment the quantity of albums and [loose] materials [in such a collection] to such an extent, that it becomes possible to master many disciplines solely from these images; for the

\footnotetext{
131 Vasari-Milanesi 1906, V, pp. 552-553.

132 Cf. above, Ch. 3.2.

133 Quiccheberg stresses Strada's role in the genesis of this section of the Fuggers' collections: 'Raimundus [the Younger] vero cum eodem fratre [= Hans Jakob], antiquarum statuarum librorumque in quibus innumera numismata privatim depingitur, tanta volumina adhibito Iacob à Strada conquisivit, ut si asportandi sunt, eis aliquot clitellarii muli debeant onerari, cuius argumenti exemplaria solum in Caesareis museis apud Maximilianum imperatorem conservantur augenturque'. (Quiccheberg/Roth 2000, p. 192); cf. above, Ch. 3 .
} 
contemplation of one single image often more enriches the memory than several days reading of many pages [of text].134

This passage is echoed in Strada's admonition to Adam von Dietrichstein to continue the practice of drawing after examples, and to ensure that his young charges, the Archdukes Rudolf and Ernest, likewise continued this practice, which shows how seriously he took the didactic and scientific aspect of the image, and more in general of visual stimuli:

$<\ldots>$ for in truth, dear Sir, by drawing one obtains knowledge of an infinite number of things, and one's judgment becomes much more excellent in all subjects, and far surpasses that [obtained by] other studies, the more so when practiced by a learned gentleman such as you are. ${ }^{135}$

These ideas were shared or taken up by other collectors of the time, and it is surely no coincidence that the three princely collections most closely connected to Fugger and Strada, those of the Duke Albrecht $\mathrm{V}$ of Bavaria, his brotherin-law Archduke Ferdinand II of Tirol and their nephew the Emperor Rudolf II each included huge collections of documentary images: illustrated books and manuscripts, atlases, albums of heraldry, portraits, technical inventions, in short every conceivable subject which could profitably be illustrated by drawn or engraved images. ${ }^{136}$

\subsubsection{The Material: Intended for Publication}

Strada's interest in images as sources of information is one of the recurring themes in his ambitious publishing programme, which will be surveyed in the next chapter. All the books that Strada published in his lifetime were illustrated, as were Ottavio Strada's Series of Lives of the Roman Emperors, based on Strada's own manuscript version, and Jacopo's technical designs which were published by his grandson, Ottavio Strada the Younger, in $1617 .{ }^{137}$ Next to Serlio's Settimo libro d'architettura the most striking is doubtless Strada's edition

134 Quiccheberg/Roth 2000, p. 138: 'Subinde ergo huius instituti fasciculi et materiae à diligentioribus patronis adeo augentur, ut quam plurimam disciplinarum ex his solum imaginibus cognitio acquiri posse videatur, plus enim quandoque praestat memoriae inspectio solum alicuis picturae quam diuturna lectio multarum paginarum?

135 Doc. 1566-03-01, quoted above, Ch. 11.6.

136 Fickler's inventory published in Diemer/Diemer/Sauerländer 2008; Archduke Ferdinand's 1596 inventory in Boeheim 1888, pp. CCLXXXVIII-CCXCIII, Regest 5556, fols. 382-401; Rudolf's 1607 inventory: Bauer-Haupt 1976, pp. 130-139

137 Cf. Bibliography, s.v. Strada, Jacopo; Strada, Ottavio [I] and Strada, Ottavio [II]. 
of Caesar's Commentaries, which was published in the same year. It was accompanied by exhaustive annotation and comments by four different scholars, some additional texts and the transcriptions of hundreds of inscriptions from Spain. Its most distinguishing feature, however, are the careful images of Caesar's battles and sieges, derived from a study of the text and other literature on ancient Roman warfare [below, Figs. 14.23-14.27]. As Ottavio Strada pointed out in a letter to his father shortly before publication, these images are very different from those supplied by Andrea Palladio in his edition of Caesar that was to come out in the same year. ${ }^{138}$ Strada had obtained the originals or copies of these images from his patron Cesare Gonzaga, lord of Guastalla, whose father Ferrante had commissioned an 'outstanding architect', seconded by a 'most learned mathematician', to record and reconstruct the battle locations on the spot. 139

In addition to the books Strada succeeded in printing, most of the works described in his Index sive catalogus were also intended to be illustrated, sometimes profusely. Though it also included objects which were proposed for immediate purchase, this Index is basically an outline of Strada's publication programme. He sent it to possible sponsors and paraphrased it in his letter to the Antwerp printer Christophe Plantin. ${ }^{140}$ Obviously the numismatic material takes pride of place, and several other archaeological and artistic projects have been referred to earlier in this chapter. But the index also describes illustrated treatises or series of images on other themes. Doubtless reflecting his Imperial patrons' interests, these include no less than five works on various aspects of Ottoman warfare [nrs 8, 9, 10, 11 and 39] as well as some compilations of Habsburg and Ottoman genealogy; but also a documentation of ancient (in this case medieval) weapons and war instruments preserved in Berne in Switzerland, which Strada had drawn himself ( $\mathrm{nr} 15)$.

Strada's ideas about the value of illustration are best deduced from the very first item of the Index. This is a huge polyglot dictionary in eleven languages, on which he had had learned men working for over twenty-five years. ${ }^{141}$ Strada's excessive encyclopaedic ambition transpires from the fact that after

138 Doc. 1574-12-5, full transcription in Appendix A; cf. Jansen 2004, pp. 188-191.

139 Caesar 1575 (verso of title page): 'Adiunctae sunt hisce quadraginta Figurarum tabulae, antehac nusquam visae $<$... $>$ Hae tabulae quondam maximo labore et studio, sumptibusq; ingentibus comparatae sunt per Illustriss. D. Ferdinandum Gonzagam Proregem Siciliae<...> qui omnia praedicta loca tabulis Geographicis ad vivum delineari curavit opera et studio Architecti cuiusdam insignis: adiuncto illi simul Philosopho Mathematico viros doctissimo, istorumq; locorum omnium cum maritimorum, tùm terrestrium peritissimo<... >'.

140 The Index sive catalogus is given in its entirety in Appendix D.

141 Index sive catalogus, Appendix D, nr. 1. 
this quarter of a century the work had progressed no further than the letter B. The letter A consisted of sixteen volumes, in all covering 2500 ample double folii 'written on both sides in very small letters'. These pages must have seemed black, impenetrable jungles, were it not for the thousands of images with which they were most literally illuminated. Again Strada first mentions his numismatic images, including images taken from gems and intaglios, but then continues with inscriptions 'and other figure of that sort, both painted panels and stones of precious marbles, and ancient tombs and monuments in which histories have been sculpted'. Apart from such by now traditional antiquarian material he moreover included designs ['delineationes'] of many other things which he had found or seen (and copied), 'of which an immense and infinite number is included in this dictionary'. Perhaps most important, he stresses twice that these images were inserted 'in their convenient order and place' or 'in their proper places': that is immediately adjacent to the subjects which they were intended to illustrate. A more immediate application of Quiccheberg's and his own convictions cited above can hardly be imagined. ${ }^{142}$

Likewise the use of images as a source of information is evident in the case of the libri di disegni produced in Strada's workshop, such as the Magnum ac novum opus, the voluminous numismatic compilation commissioned by Fugger and continued for Duke Albrecht V of Bavaria: this consisted of about ten thousand very detailed numismatic drawings and is singled out for particular praise by Quiccheberg. ${ }^{143}$ The style of the drawings included in these volumes bears this out: though carefully drawn, they can hardly qualify as works of art. They are standardized copies mostly after drawings or sketches Strada collected on his travels, blown up to the ample size required for the volumes, and in many cases probably based on an intermediary 'restored' version in Strada's own hand. This was certainly the case with the architectural reverses, which are careful reconstruction drawings of the monuments depicted, rather than faithful reproductions of the image as stamped on the coin: in this case the drawings pointedly serve as essays in antiquarian scholarship and in the advancement of knowledge, rather than as reproductions of works of art.

142 The description of the Dictionary proper is immediately followed by the description of the index to the whole dictionary (Index sive catalogus, nr. 2), which by itself also took up sixteen volumes, covering 3506 folii: it explicitly referred not only to the finding 'places' of the texts, but also those of the various objects illustrated. Strada did not propose his dictionary itself to Plantin, but proposed this index as a work of reference to be printed in three columns, and compared it to the concordance of Plantin's own famous polyglot Bible.

143 Cf. above, Ch. 3.3 and Figs. 3.23-3.34. 
The same holds also for the libri di disegni and most of the single drawings from Strada's studio that document contemporary works of art: in these copies Strada never attempted to imitate exactly the 'handwriting' of the individual artist as observed in the model: the clear outline of these copies served in the first place to document a given figurative or ornamental 'invention'. This holds both for the hundreds of drawings after designs for goldsmith work and festival trappings based on models by Giulio Romano, Francesco Salviati and others and for the drawings after classical sculpture and contemporary figurative decoration. This approach provides a clue to Strada's attitude as a collector of drawings: in analogy to the albums of such copies compiled for his patrons, his own collection of autograph drawings functioned as an overflowing repertory of motifs and inventions, inventions which could not only serve in general as a source of inspiration for the many artists present at the Imperial court and for their patrons, but could also be adapted to practical use when the need arose.

\subsubsection{Strada's Attitude to his Drawings}

Strada's interest in practical use partly explains why the concept of originality or Eigenhändigkeit was of less importance to Strada than to Giorgio Vasari or Niccolò Gaddi. These Florentine art-theorists and connoisseurs had developed an approach which attempted to understand a given work of art and the development of an individual artist in terms of a more generally formulated history of art, and this approach manifested itself in the organization of their graphic collections. Vasari had selected the drawings for his celebrated Libro de' disegni, later in Gaddi's possession, in order to create some visual complement to his Vite de' più eccellenti pittori, scultori ed architettori, and he only included outstanding and characteristic examples of the best artists from the several Italian schools since Cimabue. He considered the autograph drawing as the key to a given artistic personality, and 'modern' art-historical criteria such as authenticity and spontaneity are of importance. Consequently Vasari ordered his drawings according to artist, and the artists were grouped in local or regional schools. ${ }^{144}$

Strada's collection of drawings appears to have had a different purpose. His acquisitions concentrated on the work of Raphael and his most renowned pupils: that is on the school that was considered at the time-and for the next three centuries - as the ultimate model of perfection and elegance. Strada purchased Perino's and Giulio's collections en bloc, and apart from their autograph drawings these inevitably included many copies or studies drawn by their assistants and pupils. It is clear from Strada's descriptions in the Index

144 On Vasari's Libro, see Ragghianti Collobi 1974. 
sive catalogus that he distinguished between the sketches, studies and modelli in Raphael 's, Perino's and Giulio's own hand, and the documentary drawings of their works he had commissioned from others, and Ottavio Strada's correspondence cited above show that he counted the former among his greatest treasures. But though Strada recognized the quality of the autograph drawings, he did not lose himself in Neoplatonic speculations about the divine genius of the artists who had created them: to him authenticity of the drawings appears to have been of less moment than the pictorial or architectural invention documented in the design. This suggests that for him the practical use of a given drawing, which could function as model, or at least as a source of inspiration for the artist who studied it, was of greater value than its status as an independent work of art. His is a rather pragmatic attitude, which concerns itself with the results of the artistic creation, rather than with the spiritual life which is its moving power. A modello for a fresco in the Camera di Psiche that had been worked out in detail, under Giulio's supervision, by one of his assistants, would therefore have been hardly less prized than Giulio's autograph sketch; after all the invention, and therefore the credit, was Giulio's in both cases. ${ }^{145}$ For that reason Strada had ordered his drawings according to iconographic or functional criteria, that is according to subject, type of drawing, and potential use. As we have seen above, the misunderstanding that arose after his death between Ottavio Strada and Grand Duke Ferdinando I of Tuscany and his artistic advisers, including Niccolò Gaddi, was probably caused by this fundamental difference in attitude.

\subsection{Conclusion}

Strada's large scale commissions of documentary drawings, in addition to the original materials he had acquired from other artists, had a threefold purpose. On the one hand they were intended to serve as a source of knowledge and learning for all subjects that could not be sufficiently documented in written text alone, along the lines set out in Quiccheberg's treatise. On the other hand they were intended to serve as sources of inspiration for his patrons, their advisors and the artists and artisans they employed in their projects. Finally they provided the raw material for an ambitious publishing programme, which may have been partly motivated by commercial considerations, but which certainly

145 Perhaps Strada was influenced by Giulio's own practice; in contrast to Raphael, Giulio preferred to have his ideas executed by masters of the second or even third rank, rather than tolerate assistants whose quality might expose him to serious competition. 
also was intended to promote the reception of the formal language common to the most admired art of Strada's own time and fatherland, and that of the Ancient world, in particular of the Roman Empire.

Altogether it appears that Strada's collection of graphic material was of quite extraordinary interest: exactly contemporary with Vasari's Libro de' disegni, it was one of the first and largest collections of autograph master drawings as such and was complemented by a huge quantity of specially commissioned documentary drawings, at least a part of which—one thinks of the illuminated drawings of Raphael's Vatican Loggia - was of the very highest quality imaginable. Covering a great many artistic and antiquarian subjects, it parallels and to some extent functioned as a model for the similar sections in the Kunstkammer of his patrons. In view of its contents, its aims, and the term Musaeum which Strada explicitly and proudly used to indicate his library and collection, it can moreover be considered as a precursor of Cassiano del Pozzo's famous Musaeum chartacaeum, though the dispersal of Strada's collection and the relatively scanty archival documentation make it difficult to decide to what extent these two paper museums overlapped in purpose, in method, perhaps even in actual contents. 